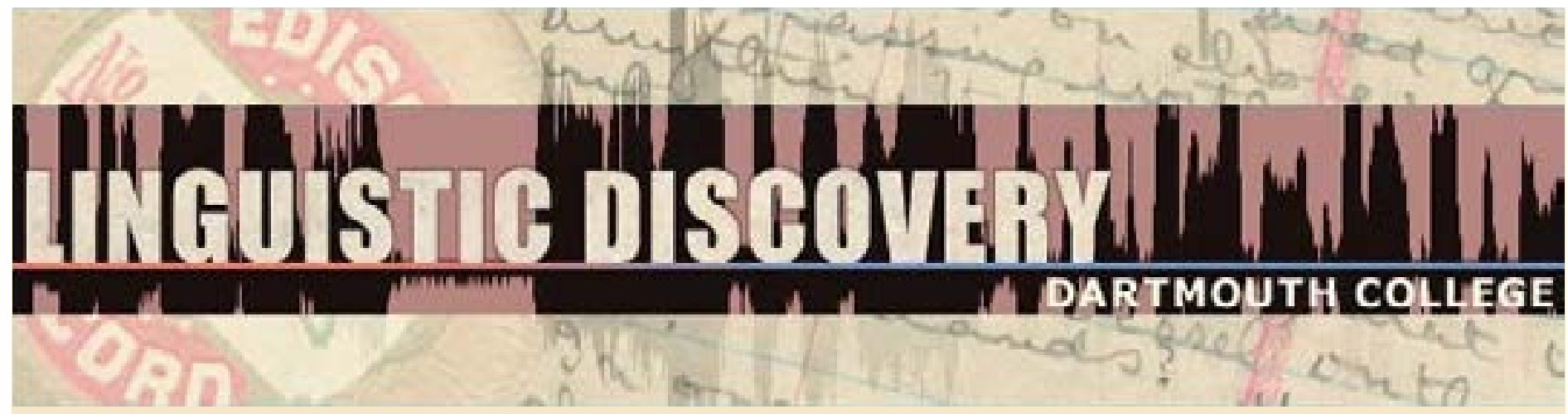

Volume 11

Issue 1 2013

\section{A Sociolinguistic Assessment of the Darwāzi Speech Variety in Afghanistan}

Simone Beck \& Daniela Beyer

doi: 10.1349/PS1.1537-0852.A.396

url: http://journals.dartmouth.edu/cgi-bin/WebObjects/ Journals.woa/1/xmlpage/1/article/396 


\section{A Sociolinguistic Assessment of the Darwāzi Speech Variety in Afghanistan}

Simone Beck \& Daniela Beyer

This paper presents a sociolinguistic assessment of the Darwāzi speech varieties (including Tangshewi) based on data collected during a survey conducted between August 31st and September 19th 2008 in the Darwäz area. The research was carried out under the auspices of the International Assistance Mission, a Non-Governmental Organization working in Afghanistan. The goal was to determine whether Dari, one of the two national languages, is adequate to be used in literature and primary school education, or whether the Darwäzi people would benefit from language development, including literature development and primary school education in the vernacular.

The researchers administered sociolinguistic group questionnaires to groups of men and women, as well as questionnaires to village elders, elicited word lists and tested and observed intelligibility of Dari. In this way we aimed to determine the domains of language use, the peoples' attitudes towards their own speech variety and Dari, and to investigate intelligibility of Dari.

The Darwäzi speak only their vernacular in the home and in the community, and they use it in the religious domain, and with some guests. They speak Dari when travelling outside the area, with some guests, with government officials and partly in school. School is the only domain that exposes girls and young women to Dari; older women have only very little contact with Dari.

Dari was found to be mostly intelligible to the Darwāzi speakers. Acquired comprehension seems to be growing rapidly as the middle and younger generation is more and more exposed to Dari radio broadcasting and television. Also, almost all Darwāzi children now go to school, where they are exposed to written Dari materials.

The Darwāzi people display a positive attitude towards Dari. Their attitude towards the vernacular is somewhat divided. Many people insist that they speak Dari, just with a different pronunciation.

As intelligibility of Dari is high after a short time of getting used to it, and the attitude towards Dari is highly positive, our opinion is that there is no need for a literacy program in the Darwäzi speech variety. In fact, people themselves do not see the need for such a program.

\section{Table of Contents}

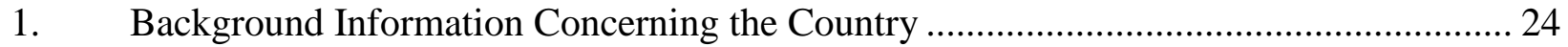

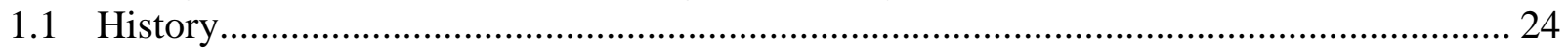

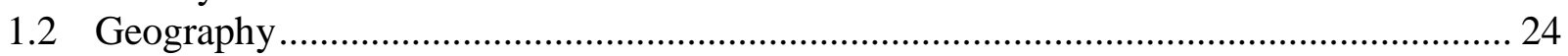

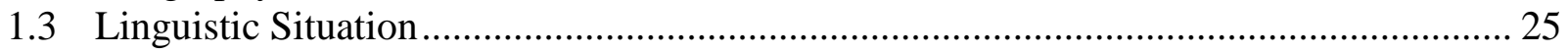

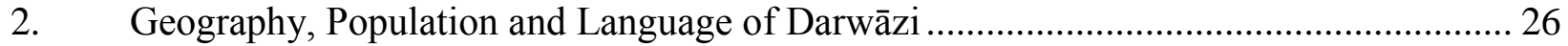

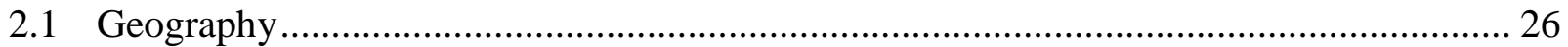

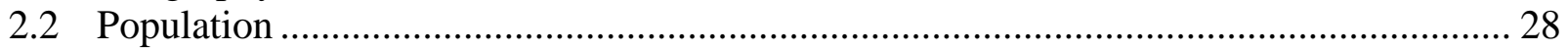

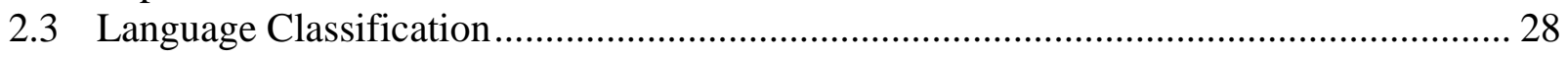

2.4 Previous Research regarding Darwāzi and Tangshewi............................................. 29

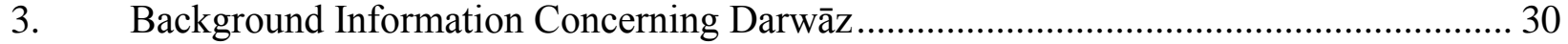

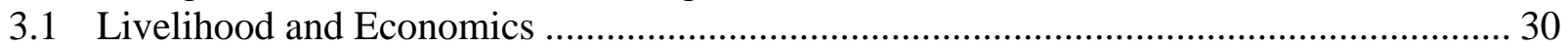




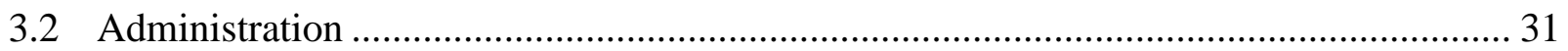

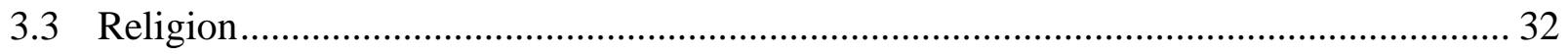

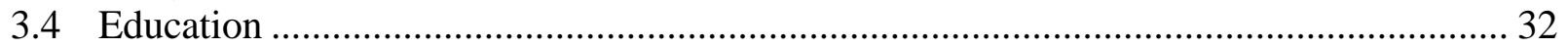

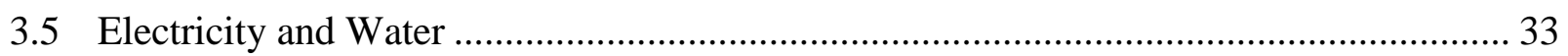

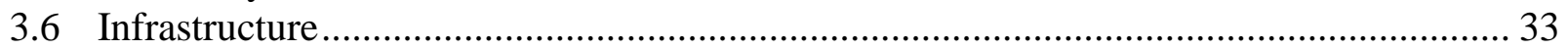

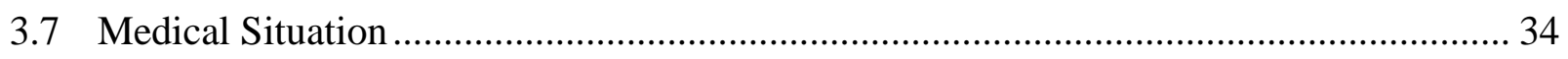

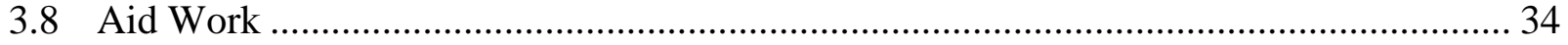

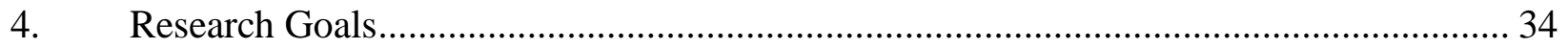

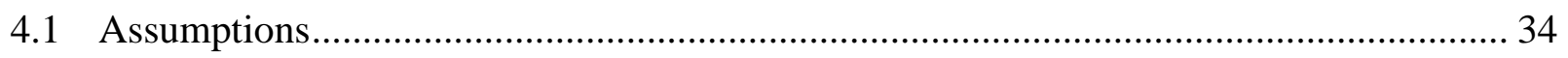

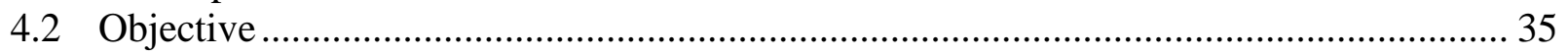

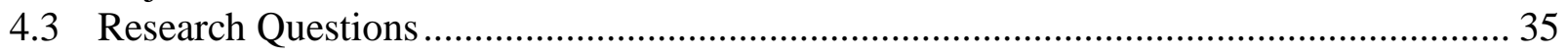

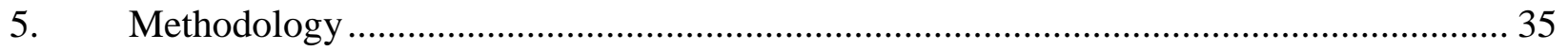

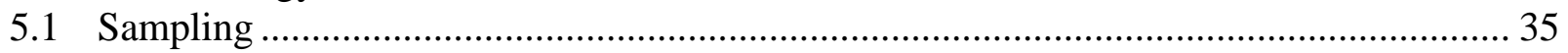

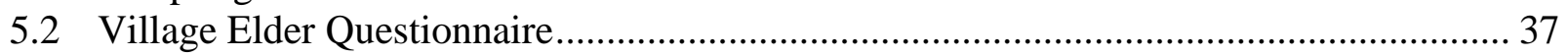

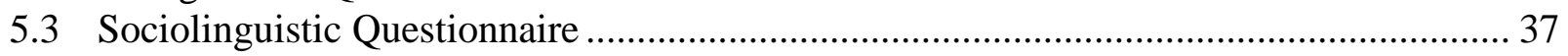

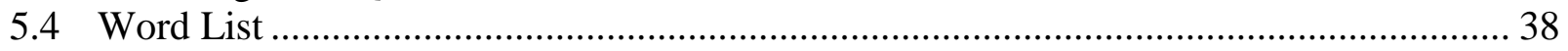

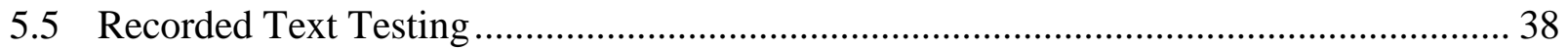

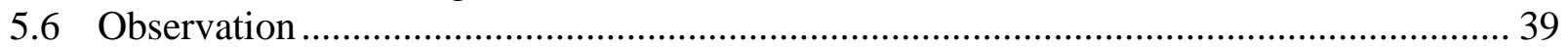

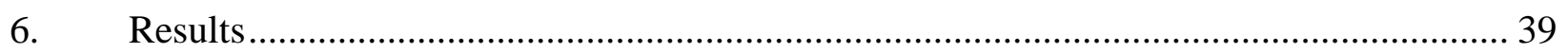

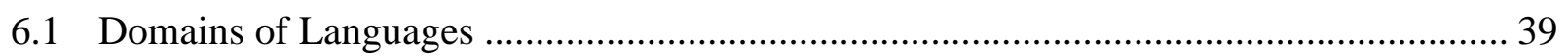

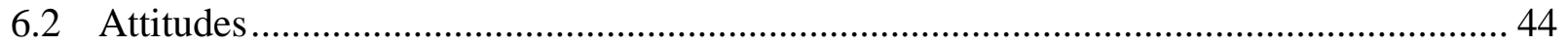

6.3 Intelligibility between the Darwāzi villages, between Darwāzi and Tangshewi, and

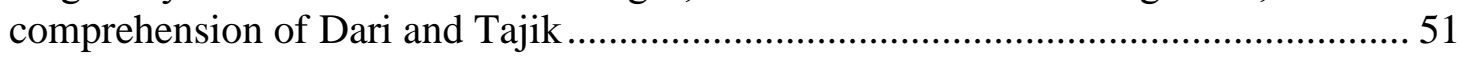

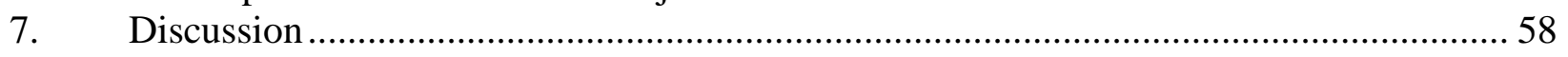

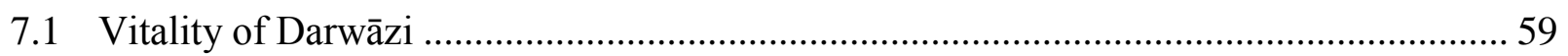

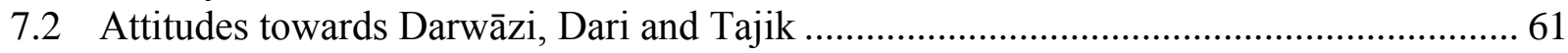

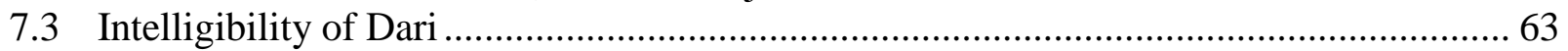

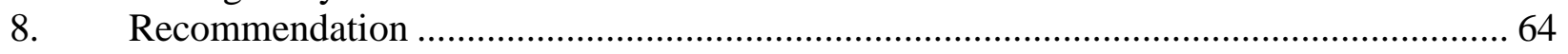

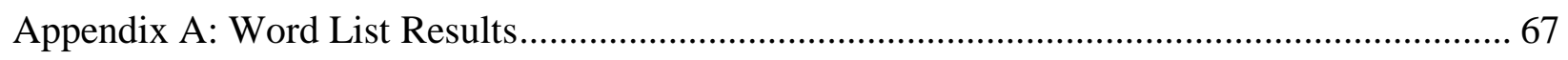

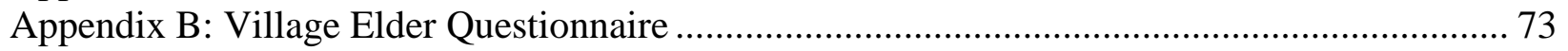

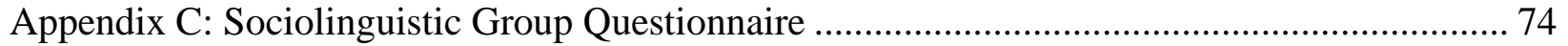

Appendix D: Stories for RTTs (with Breaks) and Questionnaire ......................................... 76

Appendix E: Poems recorded in Jumarj-e Bālā and Nusay ................................................. 81 


\section{Background Information Concerning the Country}

\subsection{History}

Afghanistan has been an area of great interest for many centuries, mainly because of its central position in Asia. Marco Polo probably travelled on the Silk Road through Afghanistan (that is through Badakhshan and the Wakhan corridor) to China. During the period of the "Great Game"1 ( $18^{\text {th }}$ and $19^{\text {th }}$ century) the Russians and the British fought fiercely over what is now the country of Afghanistan. In recent history Afghanistan has been occupied by Russia (since 1977), until they were defeated by the Mujaheddin and the Taliban began to rule the country (1995). In 2001 the Northern Alliance supported by the North Atlantic Treaty Organization (NATO) terminated the reign of the Taliban. Presently a Parliament and a President rule Afghanistan.

In recent years International Non-Government-Organizations (INGOs), the United Nations Organization (UNO) and governments of other countries have shown great interest in Afghanistan. They have invested considerable financial resources into the country, and initiated many humanitarian programs. Humanitarian efforts are currently concentrated in Kabul, other major cities and rural areas near major cities. In contrast, few resources have been allocated to rural and mountainous areas. In fact, very little is known about some of these areas.

\subsection{Geography}

Afghanistan is a landlocked country occupying a central position in Asia. It borders Iran to the west, Turkmenistan, Uzbekistan and Tajikistan (in this order from west to east) to the north, Pakistan to the east and south and it has a very short common border with China in the far east.

Map 1 shows the borders of the country of Afghanistan with its 34 provinces.

\footnotetext{
${ }^{1}$ The Great Game is a British term for what was seen by the British to be a strategic rivalry and conflict between the British Empire and the Russian Empire for supremacy in Central Asia. The classic Great Game period is generally regarded as running approximately from the Russo-Persian Treaty of 1813 to the Anglo-Russian Convention of 1907. Following the Bolshevik Revolution of 1917 a second, less intensive phase followed.

The term "The Great Game" is usually attributed to Arthur Conolly, an intelligence officer of the British East India Company's Sixth Bengal Light Cavalry. It was introduced into mainstream consciousness by British novelist Rudyard Kipling in his novel Kim (1901). (Wikipedia 2008)
} 


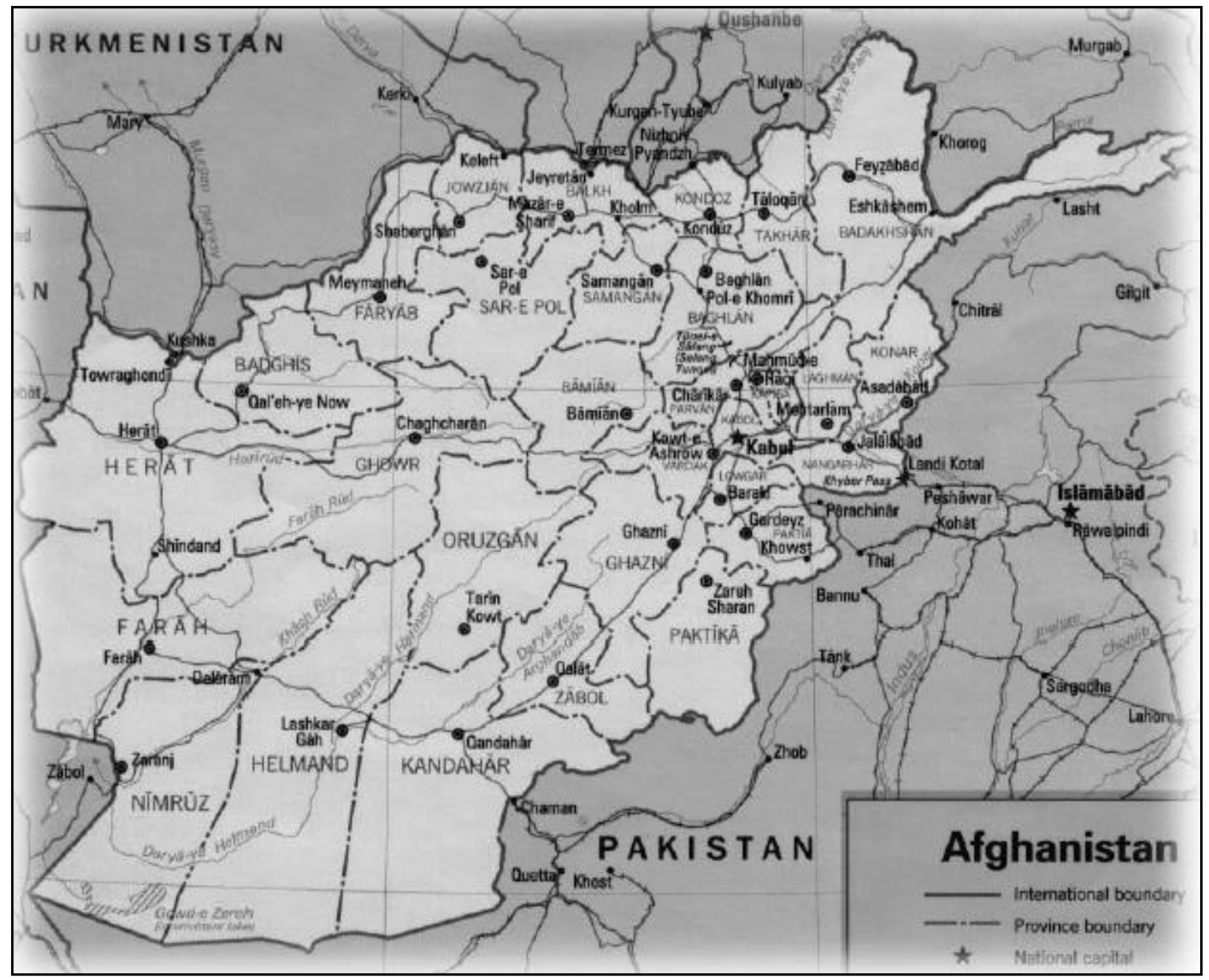

Map 1: Provinces of Afghanistan Source: afghana! (2008)

\subsection{Linguistic Situation}

The national languages of Afghanistan are Dari and Pashto. Both are Indo-European languages, Dari belonging to the West Iranian languages and Pashto to the East Iranian. The Ethnologue (Gordon 2005) lists 46 languages for Afghanistan. Many of these are also spoken in neighbouring countries, as borders were drawn without taking into account the location and boundaries of ethnolinguistic groups. According to the new constitution of Afghanistan (2005), article 16, the government supports the development and strengthening of minority languages. The status of a third national language is ascribed to some in places where the majority speaks it. Pamiri (spoken in Badakhshan) is mentioned as one of these ${ }^{2}$. Little research has been conducted into the minority languages of Afghanistan; hardly any information about them is available.

${ }^{2}$ In linguistic publication Pamiri is not considered as one language, rather the Pamir languages as a group of related languages; they are spoken in some parts of Badakhshan. 


\section{Geography, Population and Language of Darwāzi}

\subsection{Geography}

The Darwāz area (including the Tangshew valley) is located in the Badakhshan province of Afghanistan. Badakhshan forms the very north-eastern part of Afghanistan: it borders Tajikistan, China, and Pakistan. The terrain consists mostly of mountain ranges and valleys (altitude between 1000 and $6000 \mathrm{~m}$ ), the highest being the Pamir range in the Wakhan corridor.

Map 2 shows the province of Badakhshan with the Darwāz area and other places mentioned in the report. As indicated in the map, Tangshew is part of Darwāz and Roshān is part of Shighnān.

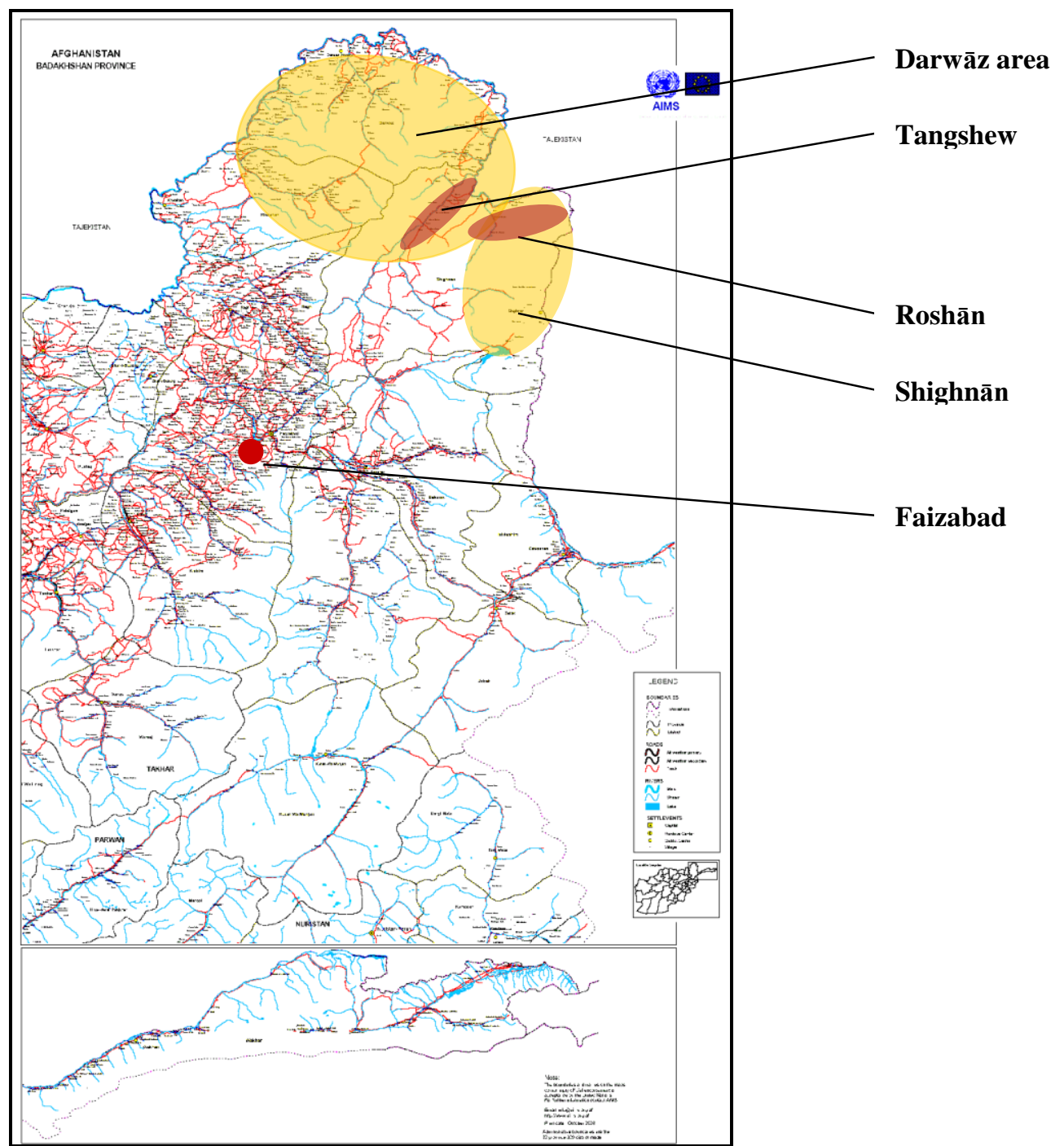

Map 2: Province of Badakhshan, with the Darwāz area and other areas Source: Afghanistan Information Management Service (AIMS 2004)

Darwāz is a mountainous region in the very north of Badakhshan. The Panj river denotes the northern boundary of Afghan Darwāz and also marks the border to Tajikistan. The Kufāb and Tangshew rivers mark the southern boundary. The villages which are situated at the river Panj are at an altitude of between about $1800 \mathrm{~m}$ and $1000 \mathrm{~m}$; the villages at the side valleys are at an 
altitude up to close to $3000 \mathrm{~m}$. Mountain passes between the Jaway and the Kufāb valleys are close to $4000 \mathrm{~m}$ high.

There are about 40 to 50 (depending on how one counts) Darwāzi villages along the river Panj, and a few more inland, near to the river Panj. There is about the same number of villages again along the side valleys of Tangshew, Shuriān and Jaway, and Kufāb. The biggest village in Darwāz is Māymay with about 1566 houses. There are many small villages, especially in the side valleys, which consist of less than 10 houses.

Map 3 shows the Darwāz area with the villages we visited, and with the longer side valleys. ${ }^{3}$

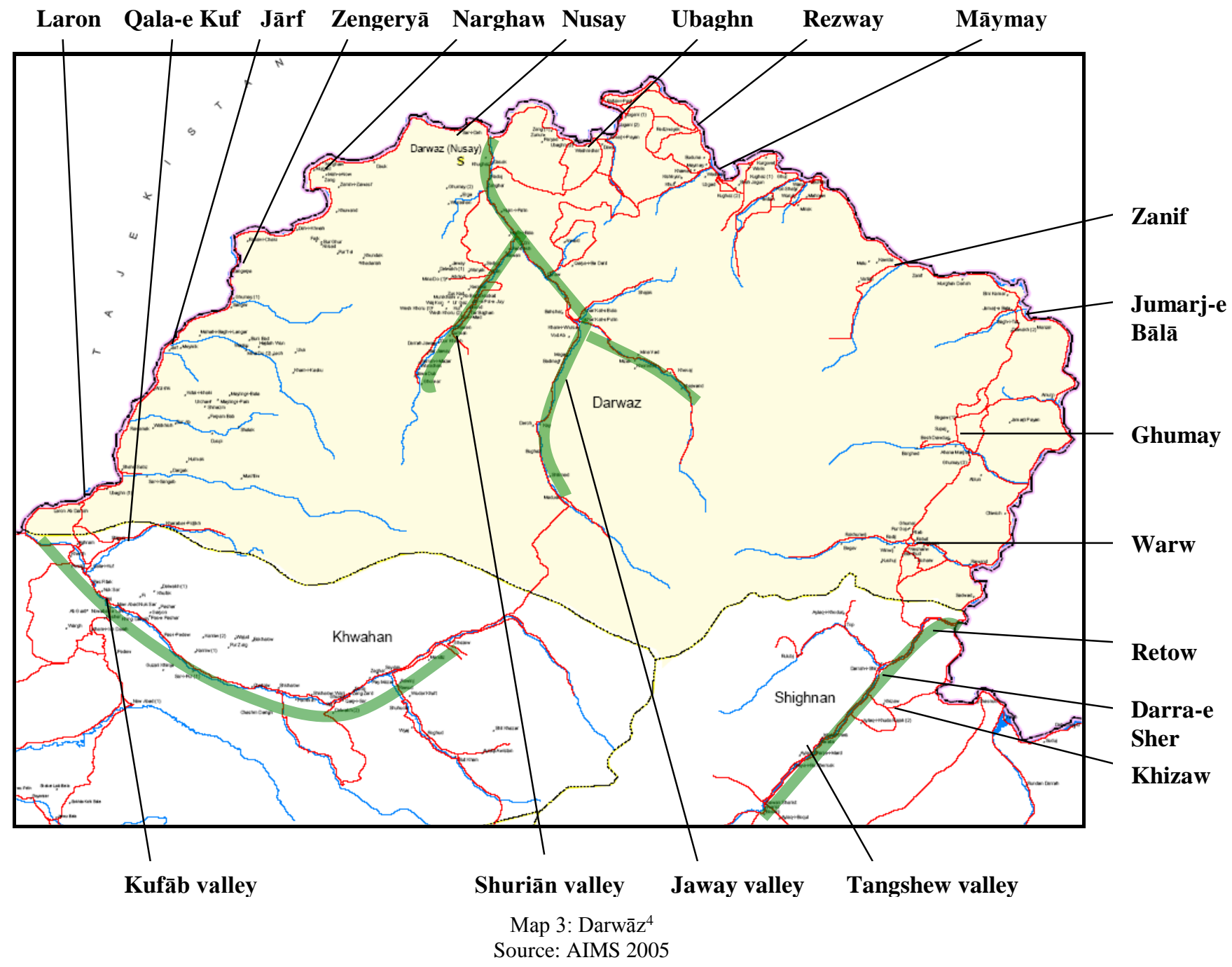

Table 1 gives the GPS coordinates and the altitude of the Darwāzi villages visited. It also indicates the walking distance to the village on the next line.

${ }^{3}$ The district border does not apply any more; currently there is no map available which shows the correct district borders and the names of the villages (see '3.2Administration' for correct district borders).

${ }^{4}$ The spelling of the village names follows the spelling used in the AIMS maps, except in cases where the AIMS spelling misleads the pronunciation of the village name. 


\begin{tabular}{|c|c|c|c|}
\hline Village & GPS coordinates & Altitude & Distance \\
\hline Retow & $\mathrm{N}: 37^{\circ} 59^{\prime} 11^{\prime \prime} ; \mathrm{E}: 71^{\circ} 14^{\prime} 04^{\prime \prime}$ & $1792 \mathrm{~m}$ & $3,5 \mathrm{~h}$ \\
\hline Khizaw & $\mathrm{N}: 37^{\circ} 55^{\prime} 30^{\prime \prime} ; \mathrm{E}: 71^{\circ} 11^{\prime} 41^{\prime \prime}$ & $2150 \mathrm{~m}$ & $4,5 \mathrm{~h}$ (via Retow) \\
\hline Darra-e Sher & $\mathrm{N}: 37^{\circ} 57^{\prime} 16^{\prime \prime} ; \mathrm{E}: 71^{\circ} 12^{\prime} 02^{\prime \prime}$ & $1901 \mathrm{~m}$ & $7,5 \mathrm{~h}$ (via pass, altitude: $3512 \mathrm{~m}$ ) \\
\hline Warw & $\mathrm{N}: 38^{\circ} 03^{\prime} 21^{\prime \prime} ; \mathrm{E}: 71^{\circ} 12^{\prime} 55^{\prime \prime}$ & $2714 \mathrm{~m}$ & $7,5 \mathrm{~h}$ (via pass, altitude: $3851 \mathrm{~m}$ ) \\
\hline Ghumay & $\mathrm{N}: 38^{\circ} 09^{\prime} 08^{\prime \prime} ; \mathrm{E}: 71^{\circ} 17^{\prime} 21^{\prime \prime}$ & $2136 \mathrm{~m}$ & 7,5h (via pass; altitude: $3280 \mathrm{~m}$ ) \\
\hline Jumarj-e Bālā & $\mathrm{N}: 38^{\circ} 16^{\prime} 37^{\prime \prime} ; \mathrm{E}: 71^{\circ} 19^{\prime} 40^{\prime \prime}$ & $1608 \mathrm{~m}$ & $3,5 \mathrm{~h}$ \\
\hline Zanif & $\mathrm{N}: 38^{\circ} 18^{\prime} 55^{\prime \prime} ; \mathrm{E}: 7^{\circ} 14^{\prime} 32^{\prime \prime}$ & $1621 \mathrm{~m}$ & $8,5 \mathrm{~h}$ \\
\hline Māymay & $\mathrm{N}: 38^{\circ} 24^{\prime} 13^{\prime \prime} ; \mathrm{E}: 71^{\circ} 02^{\prime} 60^{\prime \prime}$ & $1420 \mathrm{~m}$ & $1 \mathrm{~h}$ \\
\hline Rezway & $\mathrm{N}: 38^{\circ} 26^{\prime} 35^{\prime \prime} ; \mathrm{E}: 71^{\circ} 02^{\prime} 02^{\prime \prime}$ & $1439 \mathrm{~m}$ & $5,5 \mathrm{~h}$ \\
\hline Ubaghn & $\mathrm{N}: 38^{\circ} 26^{\prime} 36^{\prime \prime} ; \mathrm{E}: 70^{\circ} 54^{\prime} 14^{\prime \prime}$ & $1339 \mathrm{~m}$ & $4 \mathrm{~h}$ \\
\hline Nusay & $\mathrm{N}: 38^{\circ} 26^{\prime} 35^{\prime \prime} ; \mathrm{E}: 70^{\circ} 48^{\prime} 20^{\prime \prime}$ & $1281 \mathrm{~m}$ & $4 \mathrm{~h}$ \\
\hline Narghaw & $\mathrm{N}: 38^{\circ} 24^{\prime} 52^{\prime \prime} ; \mathrm{E}: 70^{\circ} 41^{\prime} 16^{\prime \prime}$ & $1208 \mathrm{~m}$ & $6 \mathrm{~h}$ \\
\hline Zengeryā & $\mathrm{N}: 38^{\circ} 18^{\prime} 49^{\prime \prime} ; \mathrm{E}: 70^{\circ} 36^{\prime} 35^{\prime \prime}$ & $1149 \mathrm{~m}$ & $2,5 \mathrm{~h}$ \\
\hline Jārf & $\mathrm{N}: 38^{\circ} 14^{\prime} 41^{\prime \prime} ; \mathrm{E}: 70^{\circ} 32^{\prime} 55^{\prime \prime}$ & $1134 \mathrm{~m}$ & $4,5 \mathrm{~h}$ \\
\hline Laron & $\mathrm{N}: 38^{\circ} 06^{\prime} 05^{\prime \prime} ; \mathrm{E}: 70^{\circ} 28^{\prime} 01^{\prime \prime}$ & $1093 \mathrm{~m}$ & $4,5 \mathrm{~h}$ \\
\hline Qala-e Kuf & $\mathrm{N}: 38^{\circ} 02^{\prime} 13^{\prime \prime} ; \mathrm{E}: 70^{\circ} 28^{\prime} 40^{\prime \prime}$ & $1401 \mathrm{~m}$ & - \\
\hline
\end{tabular}

Table 1: GPS coordinates, altitude and distance to next village

\subsection{Population}

A population survey conducted in 2002 states that more than 65000 people are living in the Darwāz area of Afghanistan (Emadi 2005).

AIMS has published a map that includes estimated population figures (AIMS 2008). It gives 65800 people for Darwāz. The map still has the old district boundaries (see '3.2 Administration'), therefore the number given excludes the Tangshew and the Kufâb valley. The number roughly agrees with Emadi's number (obviously he excluded the two valleys as well). According to the new district divisions, and to the Darwāzi people's reports, these valleys are part of the Darwāz area.

The respective village elders report that about 3000 houses are in Kufâb and 150 in Tangshew. An average of 8-10 people live in each household. That makes 1200 to 1500 people living in Tangshew, and 24000 to 30000 in Kufāb. The AIMS map gives 33700 people for the old district of Khwāhān. The major part of that district consists of the Kufāb valley; this might amount to 24000 to 30000 people. Therefore it seems likely that a rough estimate of 95000 people (65 800 previous Darwāz district +1200 Tangshew +28000 Kufāb) live in the four districts of Darwāz.

Additionally, according to Dodykhudoeva, approximately 25000 Darwāzi people live in Tajikistan, across the river of Afghan Darwāz (Dodykhudoeva 2005).

\subsection{Language Classification}

According to the Ethnologue two languages are spoken in the Darwāz area: Darwāzi and Tangshewi (Gordon 2005). They belong to the Western Iranian languages; they are probably closely related to each other, and also to Dari.

At the time of the research the Ethnologue gave the following information for Darwāzi and Tangshewi: 


\begin{tabular}{|l|l|}
\hline Darwāzi: & \\
\hline ISO Code: & drw \\
\hline Alternate names: & none \\
\hline Dialects: & none \\
\hline Classification: & Indo-European, Indo-Iranian, Iranian, Western, Southwestern, Persian \\
\hline Tangshewi: & \\
\hline ISO Code: & tnf \\
\hline Alternate names: & Tanghuri \\
\hline Dialects: & Probably closely related to Darwāzi \\
\hline Classification: & Indo-European, Indo-Iranian, Iranian, Unclassified \\
\hline
\end{tabular}

The Darwāzi people themselves refer to their language as Dari, Farsi or Tajik. They rarely use 'Darwāzi' or 'Tangshewi' for their speech variety. These names are given by linguists from the outside. If probed, people refer to their speech variety as 'Dari-e watani' (home dialect), 'Dari-e mahali' (local dialect), or 'Darwāzagi', and 'asl-e Darwāzagi' (original Darwāzi speech), or, seldom, 'Darwāzi'. To distinguish the Dari spoken in other places of Badakhshan from their own variety, they call it 'Dari-e Badakhshi' (Dari of Badakhshan) or 'Dari-e Shar' (Dari of the city).

In this paper, for the sake of being able to differentiate clearly, the names in the Ethnologue 'Darwāzi' and 'Tangshewi' are used for the varieties spoken in Darwāz and 'Dari' is used for the language as it is spoken in Faizabad and other towns.

Dari itself is not a uniform speech variety. The register spoken by the majority of the people in everyday situations differs greatly from the register used for writing, which is also used for official speeches, for TV and radio news programmes etc. This concerns vocabulary, grammar, and pronunciation. Besides this many intermediate registers between these two forms of Dari are spoken. To illiterate Afghans or to those who attended school only for a few years, the written variety of Dari is not comprehensible. When not mentioned otherwise, in this report 'Dari' refers to the register as it is spoken in towns like Faizabad and Kabul.

Information was gathered in Darwāz about the Darwāzi variety spoken in Tajikistan: The men in Māymay said that old people in Tajikistan speak exactly like they do. In Zengeryā people reported that on other side of the river there was a village with the same variety as theirs. The same is the case in Jumarj-e Bālā: they explained that in the village Vanj, at the other side of the river, the variety was exactly the same as theirs in the past, while it is different now. If these pieces of information are true, it seems that the vitality of Darwāzi in Tajikistan may be declining, although it is still spoken in at least some villages.

Darwāzi and Tangshew are spoken varieties; no written material exists so far. This is, besides a book with poems in Darwāzi that is called Sukhanwārāne Darwāzi. People in Māymay and in Nusay mentioned this book, but no copy was available.

\subsection{Previous Research regarding Darwāzi and Tangshewi}

Documented research into the Darwāzi and Tangshewi speech varieties is extremely rare.

Lorimer was the first to publish research about the Darwāzi speech variety in Afghanistan. He names it 'Badakhshani'. In his work, "The Phonology of the Bakhtiari, Badakhshani, and Madaglashti dialects of Modern Persian, with vocabularies", he gives a brief introduction into these three speech varieties, with remarks about grammatical features, some short texts and vocabulary in phonetic transcription. 
Dodykhudoeva mentions Darwāzi spoken in Tajikistan in her paper about language policies in Tajik Badakhshan. She writes that in the north of the Badakhshan Mountainous Region the dialects Vanj and Darwāz are spoken. According to her the classification of the dialects in Tajik Badakhshan is West Iranian, South-Eastern (Vanj and Darwāz), and Southern (rest of Badakhshan). She considers both of them to be close to rural dialects of Afghanistan; she writes "they are considered transitional between southern Tajik dialects and the Tajik (Dari) rural dialects of Afghanistan" (Dodykhudoeva 2002). She adds that parts of historical vocabulary came to Badakhshan dialect through Vanj, and Darwāzi dialect. It has been preserved in local Tajik, while it was lost in modern literary Tajik.

\section{Background Information Concerning Darwāz}

This section gives background information concerning the living conditions of the Darwāzi people. The information presented is the result of background research conducted in Faizabad prior to the research trip, and of research during the field trip, in particular interviews with village elders and observation.

\subsection{Livelihood and Economics}

The people in Darwāz are partly self supporting; the economy is agro-pastoral. People grow wheat, barley, corn and broad beans for their own consumption. They keep goats, sheep and cows for milk and meat, as well as oxen for farming. Many families own only a very few cattle. Few people have a donkey or a horse. Some trees provide fruit or nuts in autumn, like apples, pears, peaches and walnuts. In the northern villages some families grow potatoes, onions, tomatoes and greens in their garden, but this practice is rather rare. In the northern and western (lower) villages, people also grow melons. In Khizaw people produce their own walnut oil.

During the three or four summer months (June to September) a third to half of the women and some men of each village take their cattle to summer pastures higher up the mountains because the narrow river valley does not provide enough pasture for the livestock. They take all their household necessities with them and live in animal-hide tents or simple stone houses. They prepare milk products that keep through the winter, like cheese and dried yoghurt. Small children go with their mothers; school children stay behind with other (usually older) women of the extended family.

The main component of the diet in Darwāz is wholemeal bread, mostly baked from wheat. When people run out of wheat before the next harvest they use corn and barley, or buy flour from Faizabad or Tajikistan. The other major food item is black tea. Additionally, in the western villages people drink black tea with milk and salt. Homemade pasta is very common and contains bean flour as the main ingredient. Meat and eggs are very rare.

To supplement the basic diet, men purchase supplies in the market in Faizabad, the provincial capital of Badakhshan. It takes between one day (from Qala-e Kuf) to 8 days (from Māymay) to reach Faizabad in summer and autumn, when the passes are open. In winter and spring it takes up to two weeks because people have to walk over the passes, and from the valleys of Shuriān and Jaway it takes even longer. People living east of Māymay travel via Shighnan; people from Māymay and further west travel via Qala-e Kuf. Most families send someone once or twice a year to obtain rice, tea, sugar and oil, but also shoes, material for clothes, crockery, or small luxury items like radios and sewing machines. A few richer people also bring carpets, glass for 
their windows and other household equipment back to Darwāz. There are small bazaars in Nusay, Jārf and Qala-e Kuf, and one or two little stalls in some other villages. People who live in or near these places usually buy some supplies there. These goods are expensive, about three to five times the price of similar goods in Faizabad. This is because the traders usually buy the supplies in Faizabad or Kunduz and take them from there, via Tajikistan, over the bridge in Nusay into Darwāz. According to people's reports it costs about $\$ 1000$ to hire a truck for transportation and to pay the customs fees in Tajikistan. In Tajikistan, over the bridge in Nusay, is a shared Afghan-Tajik bazaar that opens every Sunday. Tajiks and Afghans sell their wares and buy supplies there. Afghans are allowed to visit this bazaar without a Tajik visa.

People make money by selling cattle, and sometimes even their land. People from Tangshew sell walnuts from the abundance of walnut trees that grow there. Arable land is scarce and in some villages in the north and west only $10 \%$ of the people own land. Some families run out of wheat three to six month after harvest. Young men from most villages go to Iran for two to five years to find work. At the time of research, about 1000 men from the Kufāb valley were working in Iran. They regularly send money back to support their family. At the end of their time in Iran some of them buy what is needed to set up a house and take it back to Darwāz.

\subsection{Administration}

In 1990 the Darwāz area was reorganized into four different districts. However, most maps still show the old district divisions: only one district, excluding the valleys of Tangshew and Kufäb. Map 4 shows the new divisions of the districts in the Darwāz area.

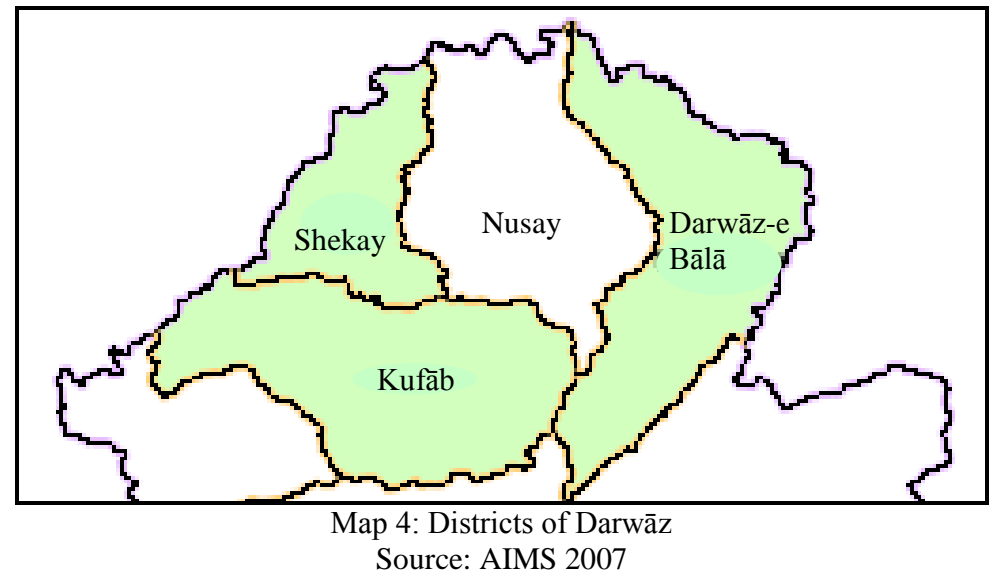

The districts are: Darwāz-e Bālā in the east, including the Tangshew valley (district capital Māymay); Nusay (or Darwāz) in the north, including the Shuriān and Jaway valleys (district capital Nusay); Shekay in the west (district capital Jārf); and Kufāb in the south, including the Kufāb valley (district capital Qala-e Kuf). A district governor is in charge of each district; they reside in the district capital and are appointed by the provincial government. The governors themselves originally come from Darwāz. Above the district governors is the provincial governor in Faizabad.

A Shorā, a village council, administers each village. The head of the Shor $\bar{a}$ is the village leader. He is responsible for all communal political affairs. The Shorā is elected in a public village meeting of all men of 18 years and older. A Shorā usually consists of 5 to 10 men. They decide among themselves who will be the head of the Shorā and who will be his deputy. Some 
Shorās also have female members who take responsibility for the women's affairs of the village. All Shorā members are elected for four years. Being a member is an honorary, un-salaried, position.

\subsection{Religion}

The people in the east of Darwāz (Tangshew valley and the eastern villages including Jumarj-e Bālā) belong to the Ismaili branch of Shia Islam. Likewise, part of Ubaghn, Zengeryā and some other villages in the west are Ismaili. According to a survey, Emadi quotes, of about 65000 people living in Darwāz almost 14000 are Ismaili (Emadi 2005). Including the valleys of Tangshew and Kufāb (see '2.2 Population') the population of Darwāz is about 95000 with 15 500 being Ismaili (Emadi's $14000+1500$ living in Tangshew). That amounts to $16 \%$. The Ismaili look to the Aga Khan as their spiritual leader; this is presently Aga Khan IV living in Paris.

Shortly after the death of Mohammad (in the year 632) the division of Sunni and Shia took place because of their differing opinions about how Mohammad's successor should be elected. The Sunnis held the view that he should be elected by a committee on the grounds of his ability, although a blood relationship to the Prophet would speak in his favour. However, for the Shias a close blood bond was the foremost criteria for all of Mohammad's future successors. The Shias did not have an opportunity to overrule the Sunnis but they themselves only recognized the fourth of the Sunnis' Imam, which was Ali, Mohammad's cousin and son-in-law. The first three Imams elected by the Sunnis were Abu Bakr, Umar and Utman (Schirrmacher 1994).

Shia is further divided into Four-Shia (although extinct today), Seven-Shia (Ismaili) and Twelve-Shia, according to the number of Imams the groups acknowledged as true Imams. They also differ greatly in theological matters. The name "Ismaili" is derived from Ishmael, the seventh and last Imam according to their view.

The Ismaili put great importance on education, practical aid and development work. In contrast to the Sunni, Ismaili usually do not keep the fast during the month of Ramadan, because, as they argue, a clean heart is more pleasing to God than outward fasting. They pray twice a day, in the morning and in the evening, while Sunnis pray five times. Ismaili do not practice the Hadj (pilgrimage to Mecca) as Sunnis do. Every Ismaili village has a Khalifa (religious teacher) and a Jumat Khāna (prayer house) where people gather to pray, and where the Khalifa preaches a sermon on Friday, usually about the practices of life according to the Ismaili beliefs. Every Sunni village has a mosque, and a Mullah for their religious instruction.

In some villages Ismaili and Sunni families exist. Although several years ago the situation was tense between the Sunni and Ismaili Muslims, at present there is no such tension; people of these different religions profess to live peacefully, side by side.

\subsection{Education}

In Afghanistan children start school at the age of seven. Classes are taught for six days a week with Friday being the day of holiday. School children attend school for two to six hours a day according to their grade. Schools are open for nine months per year; in winter schools are closed due to cold weather.

Most young children go to school apart from those in Khizaw, as they would have to cross a river without a bridge to reach the nearest school. While boys go to school for as many years as 
the school offers, many girls leave after some years. They often get married at a very early age and have to help in the household and take care of their children.

All bigger villages have at least a primary school up to grade 6 . In the district capitals and in a few other villages education up to $12^{\text {th }}$ grade is available. Māymay even offers $13^{\text {th }}$ and $14^{\text {th }}$ grades, the prerequisite for entering university and the level of education officially required to teach in schools. So far, very few students from Darwāz have enrolled in universities, as in many schools the first generation of students is only now completing their education. In eastern Darwāz, although some teachers are from Shighnān, most are from Darwāz. In the other villages all teachers come from Darwāz. The school books are in Dari and the official language of instruction is Dari; however, in lower classes the teachers usually use the local variety for explaining the lessons.

In most villages few adults are literate. Of those literate, a low proportion are women. In some villages there are no literate women. On average, according to the report of the elders of the villages, those literate may amount to roughly $10 \%$ of men and 3 to $5 \%$ of women. Most literate men and women work as teachers or are employed in an office. In Jārf, the district capital of Shekay, the doctor reported that in this district $85 \%$ of the people are illiterate.

\subsection{Electricity and Water}

In most villages small hydro power projects that people have installed themselves provide electricity for a few houses. In some villages all houses are provided with electricity in this way. Still the supply depends on the water situation and some villages have no electricity when the water is low in autumn and winter.

Most villages have springs nearby where people have access to clean drinking water. In some villages the AKDN built pipes from a spring to the village and installed taps in central places. The quality of the water is usually very good. In Narghaw a village elder has built a pipe from a spring into his house, and added a tap and a sewage pipe. This is exceptional in Darwāz.

\subsection{Infrastructure}

An unpaved road runs from Faizabad through Shighnān until the Roshān area of Shighnān. The road can only be used by cars in summer and autumn before the Sheva pass closes. It is a one day's drive from Faizabad to the the end of the motor road in Rubāt, the first Roshāni village. From the end of the road it is still about two days walk to Sadwad, the first Darwāzi village at the river Panj. The road, in most parts a small path, follows the river Panj, the border to Tajikistan. It can only be travelled by foot and by donkey or horse. On some sections it is even difficult for a donkey to continue. This path leads to Qala-e Kuf, the other end of the Darwāz area, which is frequented by public transportation in summer and autumn. According to people's reports it takes about 15 days to walk straight from Sadwad to Qala-e Kuf (see 2.1. Geography' for walking distances between villages). From this path there are several side valleys leading to further Darwāzi villages.

The government, with the help of the Aga Khan Development Network (AKDN) and the Gesellschaft für Technische Zusammenarbeit (GTZ), plans to start building a motor road in 2009. People have already started to prepare some segments of the road to be used by cars. Upriver from Nusay the next few villages can be reached by motorcycle. The vehicles have come from Tajikistan over the bridge in Nusay. 


\subsection{Medical Situation}

The Aga Khan Health Services (AKHS) provides the health care for the Darwāz area. Basic Health Centers, that is small clinics staffed by a midwife and doctor, are in Jumarj-e Bālā, Māymay, Jārf, Qala-e Kuf, and the Jaway valley. In Nusay is a Comprehensive Health Center, it has the capacity for minor surgery and for admission of patients for treatment. The AKHS has also trained health workers who give out basic medicine in additional strategic villages. Usually a man and a woman work together, the man treating the male patients and the woman the female patients. Unfortunately, people who live a long way away from a clinic do not have easy access to medical attention. When they experience an emergency they often die on the way to the clinic.

If cases are serious, patients are brought to the hospital in Faizabad. Depending on the location and the season of the year, this takes between one day and two weeks (in winter from Nusay and other villages in the north). Occasionally, people are taken to Kabul or, in exceptional circumstances, to Tajikistan. This mainly depends on the financial situation of the patient's family.

According to reports, the most common diseases are colds, coughs, pneumonia and tuberculosis. People also suffer also from rheumatism, worms, leishmaniasis and malaria, as well as general body aches and pains, like headaches, sore throats, and pain in the legs and stomach. People also complained about "women's sicknesses" in general. The doctors working in Jumarj-e Bālā and Jārf, and a nurse in Nusay reported that diarrhoea, malaria, pneumonia, tuberculosis, and birth difficulties are the biggest health problems in their clinics. The latter is highlighted by the fact that the Badakhshan province has the highest rate worldwide of maternal and infant mortality.

\subsection{Aid Work}

The Aga Khan Development Network (AKDN), a group of Ismaili (see '3.3 Religion') development agencies under the auspices of the Aga Khan, is the main aid organization working in Darwāz. The AKDN has its provincial administrational centre in Faizabad, and regional offices in the district capitals. Their work stretches across Badakhshan and into the Tajik Pamirs. They do some sections of the road building in cooperation with the German government organisation Gesellschaft für Technische Zusammenarbeit (GTZ) which is working from Faizabad. They also run a veterinary clinic in Jārf, agricultural projects in Māymay and Zengeryā, and water projects (building pipes from springs to the villages) in several villages in the Shekay district. Aga Khan Health Services, a part of the AKDN, provides the medical facilities in Darwāz (see '3.7 Medical Situation').

\section{Research Goals}

\subsection{Assumptions}

Before the research trip we held the following assumptions, based on conversations with Darwāzi people living in Faizabad or travelling through, and people from Faizabad who had been to Darwāz. 
1. Darwāzi and Tangshewi are a closely related languages, or dialects of Dari. Dari can be understood by the Darwāzi people after some time of getting used to it. Older people do not understand Dari well.

2. Even though the Darwāz area is hard to access; there is considerable amount of travelling between the Darwāz area and other parts of Badakhshan, especially Faizabad. Therefore men are regularly exposed to Dari.

\subsection{Objective}

The objective of this linguistic assessment was to find out whether the Darwāzi people can be adequately served with primary school education and literacy programs in Dari, or whether they would benefit from language development in their own speech varieties. If the latter is applies, (a) can the Tangshew people be served with the same material, and (b) might an adaptation of Tajik material be possible?

\subsection{Research Questions}

1. Living conditions: What basic information can we find out about the people groups living in Darwāz (location, population, living conditions, education, infrastructure etc.)?

2. Vitality: What is the long term perspective on the vitality of the Darwāz speech varieties?

3. Attitude: What attitudes do the Darwāzi and the Tangshew people have towards their own vernacular, each other's variety, towards Dari, and Tajik?

4. Intelligibility: To what extent are Dari and Tajik intelligible to the Darwāzi people? Are the varieties of the different villages mutually intelligible?

\section{Methodology}

This section explains the methodology used for researching the Darwāzi speech varieties.

\subsection{Sampling}

In every village we completed the Village Elder Questionnaire (VEQ) with a knowledgeable member of the community, and we elicited a Word List. We conducted two Sociolinguistic Group Interviews (SGI), one with a group of men and one with a group of women. We conducted Recorded Text Testing (RTT) with men and women of different ages.

Table 2 shows the number of questionnaires completed in the different villages, for the RTT according to the strata of gender and age. 


\begin{tabular}{|c|c|c|c|c|c|c|c|c|c|}
\hline \multirow[t]{3}{*}{ Village } & \multirow{3}{*}{$\begin{array}{l}\text { Village } \\
\text { Elder } \\
\text { I'view }\end{array}$} & \multirow[t]{3}{*}{$\begin{array}{l}\text { Word } \\
\text { List }\end{array}$} & \multicolumn{2}{|c|}{\begin{tabular}{|l} 
Sociolinguistic \\
Group Interview
\end{tabular}} & \multicolumn{4}{|c|}{ Recorded Text Testing } & \multirow[t]{3}{*}{ Total } \\
\hline & & & \multirow[t]{2}{*}{ male } & \multirow[t]{2}{*}{ female } & \multicolumn{2}{|l|}{ male } & \multicolumn{2}{|c|}{ female } & \\
\hline & & & & & $<30$ & $>30$ & $<30$ & $>30$ & \\
\hline Retow & 1 & 1 & 1 & 1 & 2 & 2 & 3 & 2 & 13 \\
\hline Khizaw & 1 & 1 & 1 & 1 & 2 & 2 & 2 & 2 & 12 \\
\hline Darra-e Sher & 1 & 1 & 1 & 1 & 2 & 3 & 2 & 3 & 14 \\
\hline Warw & 1 & 1 & 1 & 1 & 2 & 3 & 2 & 2 & 13 \\
\hline Ghumay & 1 & 1 & 1 & 1 & 2 & 3 & 2 & 2 & 13 \\
\hline Jumarj-e Bālā & 1 & 1 & 1 & 1 & 3 & 2 & 3 & 2 & 14 \\
\hline Zanif & 1 & 1 & 1 & 1 & 2 & 2 & 2 & 3 & 13 \\
\hline Māymay & 1 & 1 & 1 & 1 & 2 & 3 & 3 & 2 & 14 \\
\hline Rezway & 1 & 1 & 1 & 1 & 2 & 2 & 2 & 3 & 13 \\
\hline Ubaghn & 1 & 1 & 1 & 1 & 2 & 3 & 2 & 3 & 14 \\
\hline Nusay & 1 & 1 & 1 & 1 & 3 & 2 & 2 & 2 & 13 \\
\hline Narghaw & 1 & 1 & 1 & 1 & 2 & 2 & 2 & 3 & 13 \\
\hline Zengeryā & 1 & 1 & 1 & 1 & 3 & 2 & 3 & 2 & 14 \\
\hline Jārf & 1 & 1 & 1 & 1 & 2 & 3 & 2 & 2 & 13 \\
\hline Laron & 1 & 1 & 1 & 1 & 2 & 3 & 2 & 2 & 13 \\
\hline Qala-e Kuf & 1 & 1 & 1 & 1 & 2 & 3 & 3 & 2 & 14 \\
\hline Total & 16 & 16 & 16 & 16 & 35 & 40 & 37 & 37 & 213 \\
\hline
\end{tabular}

We visited 3 Tangshew villages. As there are only 150 houses in all villages in the Tangshew valley all together, we chose the largest villages $(8,12$ and 13 houses) to have reasonable sample sizes. We visited 13 villages in the remaining area of Darwāz. They are about half a day to one day's distance from each other on a route partly inland over passes, but mainly along the river Panj.

We took care to include bigger and smaller villages into the sample. Besides the Tangshew valley and the villages in eastern Darwāz we did not travel into any other side valleys. Even though we received uniform answers when asking people in the villages near about the language spoken in the side valleys and its intelligibility, still a minor uncertainty remains about the speech variety spoken by the people there.

When we reached a village we were usually led to the house of a village elder or another representative of the village. There, the other village residents would assemble because they were interested to see the foreign guests. Besides this, after having been given permission for the linguistic work, we would ask the host to assemble more people, male and female, of different ages, for us to talk to.

For the RTT we used stratified quota sampling applying the strata gender and age. We drew the age division at 30. The reason for this age division is that systematic and regular school education has only started fairly recently. Therefore only the younger generation, up to 30 (though often younger), has had the chance to benefit from school education on a broader scale. The sample taken was not random; obtaining a random sample would not have been culturally appropriate. However, we were able to interview both men and women of different age groups, which helped to ensure that the information gathered was reasonably representative of the entire 
community. Furthermore, no list of all the members of the communities existed from which we could have extracted a random sample.

For the group interviews we used all the men and women assembled in separate groups, by gender. We proceeded likewise for the word lists, but did not separate men and women, taking only one word list with input from both groups. The reason for this is that it is very difficult to elicit a reliable word list from illiterate people, and almost all women in this area are illiterate. The village elder interview was conducted with one knowledgeable member of the community, usually one of the village leaders or a teacher.

Interviews across gender in both locations were possible only when a female researcher was interviewing a male respondent - the other way around would not have been culturally acceptable in the area surveyed. This is due to the greater latitude afforded to foreign women when it comes to relating to local men compared to that which the local people show to their own women. Therefore the male researcher interviewed only men, while the female researchers interviewed men and women.

Dari was used as the language of communication for interviews with the men and with women. When women occasionally did not understand the questions or the researcher was unable to understand answers, other women helped with translations.

\subsection{Village Elder Questionnaire}

In every village visited we administered a village elder questionnaire to a knowledgeable member of the community, a member of the Shorā or a teacher of the local school. The questionnaire included basic demographic and language questions, questions about education, and about marriage patterns of the villagers. One section explored the living conditions in the village, like nutrition, medical situation, water and electricity supply, and help provided from outside (see 'Appendix B: Village Elder Questionnaire').

\subsection{Sociolinguistic Questionnaire}

Sociolinguistic questionnaires were administered to a group of men and a group of women, separately, in each village we visited. We separated genders because doing so is culturally appropriate, and women would rarely voice their opinion in a mixed group. Besides this, men and women might have different perspectives on the issues raised at the interview.

The questionnaire was geared towards gaining information about the speech varieties that are used in the different domains. The respondents were asked questions about marriage and travel patterns, education and work connected to language in the community.

The groups were stimulated to express their attitude towards these varieties, and were asked questions related to the vitality of Darwāzi. The questionnaire included inquiries about proficiency in Dari and Tajik, and about the mutual intelligibility of the Darwāzi varieties in the different villages.

Ideally, the groups consisted of about eight to twelve people of different age; in a few villages less people assembled, sometimes there were more. The 'perceived benefit' section was only included in the men's interview, because it included questions about finding work, higher education and travel which presently hardly apply to women's every day life. Women were also not asked about movement for work and military service (see 'Appendix C: Sociolinguistic Group Questionnaire'). 


\subsection{Word List}

To determine the degree of lexical similarity of the speech in the different Darwāzi villages, of Darwāzi with Tangshewi, and of Darwāzi/Tangshew with Dari we elicited a word list in every village. We used a 148-item word list composed of the Swadesh 100 Word List (Swadesh 1955) and a list that was used earlier for linguistic assessments in other parts of Badakhshan (Miller 2006). It seemed to be inappropriate to ask for verbs in the infinitive form from people with mostly very basic or no education. Instead we asked for each verb ( 22 items) in the $3^{\text {rd }}$ person singular past and non-past tense (see 'Appendix A: Word List Result').

The elicited word lists were entered into the computer program WORDSURV (Wimbish 1998; JAARS 1994) for further analysis. The program performs a count of shared vocabulary between lists based on similarity groupings, classifying apparent cognates "based on their appearance," rather than historical analysis.

\subsection{Recorded Text Testing}

We used Recorded Text Testing (RTT), originally developed by Casad (1974). The story is 4 minute and 3 second long tale from Afghanistan which is not commonly known in Badakhshan. We recorded it from a man in Faizabad who told the story in the register of spoken Dari. Using a story told in the spoken register of Dari is not inconsistent with the objective of the assessment, even though it is geared towards evaluating whether students are served well with written Dari material in school. When children in other parts of the country, like Faizabad, or Kabul, start school they are only familiar with the spoken register of Dari and can cope well with a gradual switch to written Dari (which is also spoken in higher classes and university). If the variety of Dari spoken in Faizabad is intelligible to the Darwāzi people they would have roughly the same starting conditions for school as Dari-speaking children.

We divided the story into twelve sections, each section consisting of two to three sentences. Before using it for research with the Darwāzi people we played the story to five people in Faizabad and asked them to retell the story section by section. The elements everyone remembered were used to make up the RTT scoring key in Darwāz. It seems that these elements are considered important by the mother tongue Dari speakers for understanding the story. To aid with scoring participants, one 'point' was assigned for each of these key elements. The highest possible score for each section was between three to five points. The first section was not counted in order to allow the testees to get used to the testing procedure.

During testing we paused the recording after every section and asked the testee to retell what they had heard. We probed for missing information with appropriate questions, in case people had understood but did not remember to retell. We made notes of the items that were missing in spite of the probing to find any possible inconsistencies within the story or the reason for any reoccurring mistakes. In this way we came up with a percentage of each person's reproduction of the story. We were also able to calculate the average for all the testees with an average of certain segment of the population like women/men or younger/older.

Based on experiences in remote areas and on the information gathered before the research trip we expected that nearly all men, but very few women, would have had previous contact with Dari speakers. Therefore, we assumed that testing for inherent, as opposed to acquired, intelligibility between the two varieties would not be possible with men. To confirm this, the 
RTT result sheet also contains a section about individuals' travel patterns and contact with Dari speakers.

See 'Appendix D: Stories for RTT (with breaks) and questionnaire' for the transcription and translation of the Dari story, with indications about how it was broken up for the RTT and for the questionnaire that was included in the RTT.

\subsection{Observation}

Throughout the whole journey we observed people interacting with each other: interacting in the street, in houses, interactions of people working together and - of course - interactions with us as foreign researchers. As all researchers possessed a Dari proficiency level of at least 3, we were able to follow most interactions that took place in Dari and some that were conducted in Darwāzi. Observation was especially important as an additional informal means for assessing the ability to understand Dari.

\section{Results}

This section gives the results obtained. The presentation of results is divided into the areas of language domains, language attitudes, and intelligibility of Dari, Tajik, and the varieties of Darwāzi.

In the results section when Darwāz is mentioned, we are including the Tangshew villages in most instances as the Tangshew valley geographically, politically and linguistically is part of the Darwāz area. Only in '6.2 Attitudes' are Darwāz and Tangshew handled separately (as well as in a few other instances, as indicated).

\subsection{Domains of Languages}

This section analyses language use by domain.

The domains of language are divided into primary and secondary domains. Table 3 shows which domains are considered primary and which are considered secondary.

\begin{tabular}{|l|l|}
\hline Primary Domains & Secondary Domains \\
\hline Private Domain & Education Domain \\
Community Domain & Religious Domain \\
& Travel and Trade \\
& Media \\
& Administration \\
\hline
\end{tabular}

Table 3: Division of language domains in primary and secondary domains

The majority of people's daily interactions occur in the private domain and the community domain. The 'private domain' refers to family life, that is, language use within the context of family interactions; 'community domain' refers to the village life, to the language use within the neighbourhood in daily interactions for community and cultural events. From infancy onwards every child is part of its family and community; these are the domains where the child first acquires its language, therefore we consider them primary domains. Many people have limited or no access to the other domains, and they are not part of their daily life, like school education, 
religion, travel and trade, media, and government administration; therefore we consider them secondary domains.

The information presented in the following section is the result of the answers given in the Sociolinguistic Group Questionnaires and the Village Elder Questionnaire.

\subsubsection{Private Domain}

Only Darwāzi is spoken in the primary domain of the home and the family.

In all villages both men and women said that everyone, of all generations, speaks Darwāzi in the house. This is apart from one Shughni-speaking family in Khizaw. When children are small they learn Darwāzi from their parents and speak it to each other.

In all eastern villages we visited including Jumarj-e Bālā, Shughni-speaking women (from Shighnān) have married Darwāzi men and moved to Darwāz. They all learned Darwāzi and speak it with their husband, children, and other family members. Only one Shughni wife married to a man in Khizaw speaks Darwāzi to her husband, although she does speak Shughni to her children. To the west, beyond Jumarj-e Bālā, Shughni wives are few. One lives in Rezway, one in Ubaghn, and one in Nusay. They all learned Darwāzi and speak it to their husband and children. They say that it was difficult first, but that they did acquire Darwāzi. Very few Darispeaking wives have married a Darwāzi man and moved to Darwāz. Those that have mainly come from Faizabad, very few from other Afghan cities, like Kabul or Kandahar. Of the villages we visited, Dari-speaking wives live in Zanif, Māymay, Nusay and Jārf. They all have got used to Darwāzi and speak it with their family. One Dari-speaking wife in Māy may reported that it had been difficult in the beginning.

Wives are given to men living outside of Darwāz from most villages we visited. Daughters are given to Shighnān from the villages in the east up to Warw, as well as from Jumarj-e Bālā, and Ubaghn. They all acquired Shughni. From all villages, except the eastern villages, wives are given to men living in other parts of Afghanistan. They have moved to Faizabad, Kabul, Kunduz, Mazar, Taloqān and other Afghan cities, one even to Iran, one to Tajikistan (the latter two from Jumarj-e Bālā) and one to Canada (from Ubaghn). As far as people knew all of these wives have got used to the variety of Dari spoken in the respective cities or have acquired English (in the case of Canada).

In the primary domain of family and home within the Darwāz area Darwāzi is used almost exclusively.

\subsubsection{Community Domain}

People in villages reported that they use predominantly Darwāzi in the primary domain of the community. They speak Dari only to the few outsiders who visit the village.

All village elders use Darwāzi when talking to each other, and when talking to the people in their village. They only speak Dari to guests from communities outside of Darwāz.

Darwāzi is the language that children grow up with in their community. All groups explained during the interview that their pre-school children speak only Darwāzi. Local Darwāzi school teachers, who are in the majority, speak Darwāzi to the school children when they meet outside school, and even on school grounds during breaks between the lessons (see '6.1.3 Education Domain' for the language of instruction in school). 
The Darwāzi people exclusively use Darwāzi with each other in their own villages. Everyone understands and speaks Darwāzi. As most villages can not be accessed by car, guests are few. Most traders who come to sell their wares are originally from Darwāz. If other guests come, e.g. from a development agency, the Darwāzi men switch to Dari when talking to them. Women hardly speak to guests coming from the outside.

However, many men have worked for several years in Iran. There they have adapted to Farsi, which they claim to be very close to Darwāzi. In informal conversations people reported that some of these men continue to speak Farsi or Dari when they return to their family in Darwāz. People stated that in this way other members of the community, men and women, also acquire Dari slowly.

Darwāzi is the predominant language in the primary domain of the village community.

\subsubsection{Education Domain}

Dari is the formal language of the secondary domain of education in Darwāz, but Darwāzi is also used informally to a considerable extent.

The language of instruction in the schools is Dari, and all school books used are in Dari. Nevertheless, the teachers who are from Darwāz help the students in Darwāzi and give explanations in Darwāzi, especially in the lower grades. Some respondents reported during the group interview that usually in $1^{\text {st }}$ to $3^{\text {rd }}$ grade the teachers teach entirely in Darwāzi, and in the following grades they gradually use higher registers of Dari. Currently, many teachers do not have a full school education themselves and are sometimes not able to teach in the spoken register of Dari as is done in the lower classes of other schools in Badakhshan, e.g. in Faizabad. In Rezway the researchers met a female teacher whose attempts to speak Dari was not intelligible to them.

During the breaks the students speak almost exclusively Darwāzi to each other and to the teachers. Even though Dari is the formal language of education, Darwāzi can be considered the informal language of the education domain.

\subsubsection{Religious Domain}

Dari is the formal language in the secondary domain of religion, but Darwāzi is also used, informally.

In both Ismaili and Sunni communities, prayers and religious instruction are written in Dari. Therefore, Dari is the official language of religion. Concerning the Ismaili villages, the religious instruction about the faith and letters from the Aga Khan for reading in the communities is written in Dari.

Most groups agreed that they use the local dialect when praying. However, in some Sunni villages people mentioned that they sometimes pray in Arabic; they also pointed out that the Quran readings are always in Arabic. Likewise people reported that their Mullah (in Sunni villages) or Khalifa (in Ismaili villages) preaches in Darwāzi.

Even though Dari is the formal language of religion, people's practice of religion, their prayers are usually carried out in Darwāzi, and the verbal religious instruction is in Darwāzi. Therefore Darwāzi can be considered the informal language of religion. 


\subsubsection{Travel and Trade}

Dari is the dominant language used in the secondary domain of travel and trade. Occasionally Darwāzi is used as well.

Most villages, especially the eastern ones, do not have a bazaar and are not visited by traders. Only occasionally traders from outside come to Warw, Ghumay, and Jumarj-e Bālā to sell their wares. Men talk in Dari to the traders. Women do not talk to the traders; it is men's business to buy the necessary supplies. Most western villages, from Zanif on, have at least one small stall. Most shopkeepers originally come from the village and they talk Darwāzi to their customers.

In all villages men travel beyond Darwāz to buy household supplies, mostly food items for their families. Once or twice a year, a male from almost every family makes this trip, usually to Faizabad. They speak Dari with the shopkeepers there. A few traders travel through Tajikistan. They buy supplies in Kunduz, and transport them via Tajikistan over the bridge near Nusay into Darwāz. In Tajikistan they speak Dari.

People, mostly from the western villages, travel to the cities of Afghanistan, like Faizabad, Kabul, Mazar, Kunduz, and Taloqan, to visit relatives. As some young women have married men living outside of Darwāz, sometimes the extended family comes for a visit. The visitors usually speak Darwāzi to the family members. Some people travel to Tajikistan to visit relatives, as their families are split between Tajikistan and Afghanistan. These family meetings usually take place at the shared bazaar over the bridge from Nusay in Tajikistan. On these occasions people also speak Darwāzi.

A few people travel outside Darwāz to take patients to the hospital in Faizabad or even Kabul. Apart from those that have travelled for medical reasons, many women have never left the Darwāz area. Those with the means to travel to Faizabad hospital are escorted by a male relative who talks for her to the medical staff in Dari.

In most villages we visited there are some men who have worked for several years in Iran to earn money. In Zanif people said that about half of the men are in Iran. From the Kufāb district (3000 houses) about 1000 men presently work in Iran. This is due to extremely low employment opportunities in Darwāz, as well as to the small size of the fields and the lack of rain to harvest enough wheat for the whole year. While in Iran these men use Farsi. People who have been in Iran claim that they can easily communicate in Iran after a short time of getting used to Farsi, which they claim to be similar to Darwāzi. A few men from most villages visited have served in the military for several years, most of them in Kabul, Mazar or Kunduz, and a few in Faizabad, Kandahar or Paktya. They all spoke Dari during that time.

Even though Dari is the dominant language used in travel and trade, Darwāzi is used occasionally with traders originally from the area and during visits to Darwāzi family members who have moved away.

\subsubsection{Media}

Dari and Tajik are used equally in the secondary domain of media. Darwāzi is very slightly used in this domain.

All groups reported that they listen to the Dari-speaking radio programs; they also listen to the Tajik broadcast from Tajikistan. In four villages of those we visited a man in the male group reported that he listened to Pashto and in two other villages men listened to Farsi from Iran. 
In all villages except Khizaw, at least a few people read books. In some villages this may only amount to one or two adults. The illiteracy rate is high; it is higher among women than men (see '3.4 Education'). However, some men and a small number of women do read books in Dari. Besides Dari, people in four villages mentioned that Arabic is used for religious literature. A female teacher in Māymay added that she reads books in Pashto and English as well. In Jumarj-e Bālā and in Nusay people mentioned a Darwāzi poetry book and some men in Nusay recited a Darwāzi poem which is written in a Dari poetry book (see '2.3 Language Classification' and 'Appendix E: Poems recorded in Jumarj-e Bālā and Nusay').

Dari, and closely the related Tajik and Farsi, are almost exclusively used in the domain of media.

\subsubsection{Administration}

Dari and Darwāzi are used about equally in the secondary domain of administration. About half of the village elders speak Dari with the governor and the other half speaks Darwāzi. Government interactions are usually limited to the district governors who reside in the four districts' capitals: Māymay, Nusay, Jārf, and Qala-e Kuf. The present governors in Māymay and Qala-e Kuf are themselves from Darwāz and speak Darwāzi in their administrational office. Nevertheless, the village elder of Zengeryā explained that usually in government offices a variety of Darwāzi is used that is a bit higher and therefore closer to Dari.

Some village elders from several eastern villages have sent a delegation to Kabul to complain to the president about the government's negligence of the development of the Darwāz area. The complaint mainly concerns the lack of a motor road leading to their villages. In government interactions like this, outside of Darwāz, Dari is used.

The languages of administration are Dari and Darwāzi.

\subsubsection{Summary}

Darwāzi is the language spoken most frequently by Darwāzi people.

Table 4 summarizes the language use of Darwāzi, Dari, Tajik (Tajikistan) and Farsi (Iran) according to the different domains. Tajik and Farsi are included here because the knowledge of them enhances the familiarity with other varieties of the language besides Darwāzi. Other languages that were mentioned, like Arabic and Pashto, used very occasionally in some domains, are not considered here because they do not influence the use and vitality of Darwāzi.

\begin{tabular}{|l|l|l|l|l|l|}
\hline & Domain & Darwāzi & Dari & Tajik & Iranian Farsi \\
\hline \multirow{2}{*}{$\begin{array}{l}\text { Primary } \\
\text { Domains }\end{array}$} & Private & exclusive & none & none & none \\
\cline { 2 - 6 } $\begin{array}{l}\text { Secondary } \\
\text { Domains }\end{array}$ & Education & informal & formal & none & occasional \\
\cline { 2 - 6 } & Religion & informal & formal & none & none \\
\cline { 2 - 6 } & Travel/Trade & occasional & frequent & occasional & frequent \\
\cline { 2 - 6 } & Media & none & frequent & frequent & none \\
\cline { 2 - 6 } & Administr. & frequent & frequent & none & none \\
\hline \multirow{7}{*}{ Table 4: Overview of domains of language in Darwāz } & \\
\hline
\end{tabular}


In the two primary domains of the home and the community, Darwāzi is spoken almost exclusively. It is the only language that is spoken in private homes and it is the dominant language of the village community. Darwāzi is used informally in the domains of education, and religion and it is frequently used in government administration. It is used occasionally in travel and trade, but not in the media.

Dari is used occasionally in the two primary domains, hardly in the private family domain, but, again, occasionally in the community village domain. It is the formal spoken language in education and religion. It is also frequently used in travel and trade, in media and in government administration.

Tajik is spoken occasionally when people travel and it is used frequently in media, when people listen to radio and watch TV from Tajikistan. Farsi is spoken occasionally in the village community by men returning from Iran. It is used frequently in the travel and trade domain, when men go to Iran to find work there.

\subsection{Attitudes}

This passage describes which attitudes the Darwāzi and the Tangshewi people each hold towards their vernacular, towards each other's speech variety, towards Dari, and towards Tajik.

\subsubsection{Towards the vernacular}

\section{Darwāz}

In almost all villages the men and the women anticipate that their children will speak Darwāzi when they are adults. However, in Ghumay the men predicated that in some homes the families will use Dari. In Zengeryā the men added that children will only speak Darwāzi in the future if they continue to live in Darwāz. In Jārf the men hypothesised that the language of the children will change if they go to school; the women said it might change if they move to a city. In Qala-e Kuf the men expected the children to talk like people talk in Faizabad when they are adults.

Likewise almost all interviewees agreed that their grandchildren will speak Darwāzi when they are adults. A few people raised the same issues that might influence or change the grandchildren's language as they had for the children. They expect future generations to generally speak the same as the present generation does, but moving away and school education might change the speech of some. Everyone reported being happy that future generations are likely to continue speaking Darwāzi. When asked how they would feel if language shift were to take place, interviewees did not react negatively; they seemed to have positive attitudes towards every speech variety future generations might use.

Seven groups (out of 26) indicated during the interview that they would appreciate school material in Darwāzi and would like children to become literate in Darwāzi. They argued that this would help the children in school. The men in Zengeryā added that in this way the dialect would not be forgotten by future generations. Six groups also would like to have books in Darwāzi for adults; they especially wanted books about health and history, and also Darwāzi poems and stories. Twelve groups were pleased that school books are in Dari right from the first grade, eight of them explicitly stated that no need exists for schoolbooks and literacy teaching in Darwāzi. Even though most people agree that children do not understand Dari well when they enter school, they are of the opinion that students get used to Dari with time. In many groups people 
stated that there is no difference between Dari and Darwāzi anyway, as they themselves call their local variety Dari.

In the perceived benefit section, about half of the groups find Darwāzi useless for finding work and for higher education and the other half pointed out that the usefulness of Darwāzi in these two areas is limited. Very few groups said that Darwāzi was 'useful' in both areas. However, for communication with other communities, about two thirds found Darwāzi 'useful in a limited way'; of the remaining groups half found it 'useful' and the other half 'very useful'. In respect of gaining honour in the home community, Darwāzi was perceived as 'useful' by very few groups and 'very useful' by three quarters of all groups.

At the end of the sociolinguistic group interview people were asked to express how important they felt Darwāzi to be for themselves personally. All groups apart from one responded by saying that the language is valuable to them, and that they like their language. Remarks were made like, "we love it as much as you love your mother," "we like it just like everyone likes his father's land," and "it is our mothers' tongue, we got used to it with our mothers' milk." The one group that responded negatively, the men in Warw, reported that the language was not important because it was a simple language.

\section{Tangshew}

All groups of interviewees anticipate that their children will speak Tangshewi when they are adults. Likewise everyone anticipates that their grandchildren will speak Tangshewi in the future when they have grown up. No one imagines that in the future people in Tangshew will not speak their local variety. Everyone agrees that this is a good thing.

Even though, no one in the three Tangshew villages we visited would like their children to become literate in Tangshewi. They call themselves Dari-speakers and do not see a need for school teaching to be in Tangshewi. They do not desire books for adults in Tangshewi either. Many people are not aware of the difference between Dari and Tangshewi, especially women who travel little. In one of the villages no children go to school and no adults are literate. For some of the groups it was therefore somewhat difficult to interact with questions related to school education; they did not have an opinion about those issues.

Tangshewi is perceived to be 'useless' for finding work by two thirds of the groups and 'useful' by one third. Everyone said it is useless for higher education. For communication with other communities two third are of the opinion that it is 'useful' and one third that it is 'a bit useful'. All villages think that Tangshewi is useful for gaining respect in the home village.

When people were asked about the importance of Tangshewi for themselves personally everyone responded in a positive way, they said they like their language and it is important for them. One group pointed out that it was a better and purer speech than Dari.

\subsubsection{Towards the other speech variety}

\section{In Darwāz towards Tangshewi}

The Darwāzi seem to hold an indifferent attitude towards Tangshew. They are a small a group and do not play a significant enough role in the life of the Darwāzi to warrant a distinct attitude towards them. People living in the eastern villages of Darwāz state that in Tangshew people 
speak in a very similar way; some even state that it is the same. People living in western villages have hardly heard of Tangshew.

In most villages parents reported that they would give their sons and daughters in marriage to Tangshewi people. Only in Warw, the village closest to Tangshew, did the men indicate that they do not wish to have a Tangshewi son-in-law or daughter-in-law because they do not like Tangshew people. In some of the western villages interviewees were not happy with the idea of their daughters marrying into the Tangshew group because they said that Tangshew was too far away and their daughters would become homesick.

\section{$\underline{\text { In Tangshew towards Darwāzi }}$}

Everyone except the group of women in Retow agreed that they would allow their son to marry a Darwāzi wife, and they would also agree to give their daughter in marriage to a man from Darwāz. They claimed to speak the same language as the people in Darwāz; they perceive themselves as part of the Darwāz area and speech variety. In Khizaw the people said: "We are Darwāzi and this is Darwāz." When asked whether the valley was not called Tangshew they replied: "Tangshew is part of Darwāz."

\subsubsection{Towards Dari}

\section{Darwāz}

More than a third of the groups interviewed were of the opinion that the best way to teach literacy in schools is Dari, as is currently practised, because they consider themselves to be Dari speakers. In Warw the group of men said that they "want to improve the language and the culture of the village"; they felt teaching in Dari in school was a means of achieving this goal. However, they could not explain what they meant by an "improved language".

Almost everyone would appreciate a Dari-speaking daughter-in-law from one of the cities in Badakhshan. But in most villages people complained that no new bride would want to come and live in Darwāz. Likewise almost everyone would be willing to give their daughters away to a Dari-speaker, the only objection being that they would have to live too far away and they would feel sad and lonely. This does not imply a negative attitude towards Dari-speakers.

Asked about the benefit of Dari, half of the groups pointed out that Dari was 'very useful' for finding work, for higher education, and for communication with other communities. The other half perceived that is was 'useful' in these areas of life; only very few found it 'a bit useful', or pointed out that its usefulness was limited to Dari speaking areas. Male and female groups in nearly all villages agreed that Dari was 'very useful' to gain respect in one's home community; only one group replied with 'useful'.

After listening to the Dari RTT story which had been recorded in Faizabad, everyone stated that the story was told in good Dari, and that the story teller had used a beautiful language.

\section{Tangshew}

Everyone agreed that it would be good for children to both become literate in Dari and to use schoolbooks in Dari. 
All groups of respondents except the group of women in Retow would allow their son to marry a Dari-speaking wife. Likewise, no-one, except the same group, would resent a Darispeaking son-in-law. This particular group does not approve of their children marrying outside of the village in general. Most are doubtful that anyone from a Dari-speaking town would like to come and live in a place as remote as Tangshew.

Two thirds of the groups perceived Dari to be 'useful' for finding work and one third found it 'very useful'. For education, two thirds found Dari 'useful', and the other third 'very useful'. The same was perceived for communication with other villages. There was no consensus on whether the ability to speak Dari is seen as a prestigious attribute in the home village: one third said that it was 'useless', another third that it was 'useful', the last third that it was 'very useful'.

RTT subjects described the language of the Dari story (recorded in Faizabad) as a very nice and beautiful.

\subsubsection{Towards Tajik}

\section{$\underline{\text { Darwāz }}$}

People's perception about the benefit of Tajik were diverse. For all four areas the perceived benefit of Tajik ranged from 'useless' to 'very useful'. A third to half of the villages found Tajik to be of no use for work, education, communication with other villages, and gaining respect in the home village. Some people added that Tajik was only useful if one travels to Tajikistan. Only a quarter of the villages found Tajik 'very useful' for finding work, and hardly anyone judged Tajik to be useful for higher education and for communication with other villages. However, a third of the villages found Tajik very useful for gaining honour in the home village. Even though the people regard Tajik in a somewhat ambiguous way, attitudes towards are positive enough for a third of the groups of men to report that one gains honour by being able to speak it.

\section{$\underline{\text { Tangshew }}$}

For every area of life mentioned in the perceived benefit section, finding work, higher education, communication with other villages and honour in the home village, a few groups found Tajik to be of no use. The remaining groups answered for all areas mentioned with a 'bit useful' (communication with other communities) or 'useful' (for finding work, higher education, and honour in the home village). Tajik was never perceived as 'very useful'.

\subsubsection{Summary}

Figure 1 shows in what language parents would like their children to become literate. 

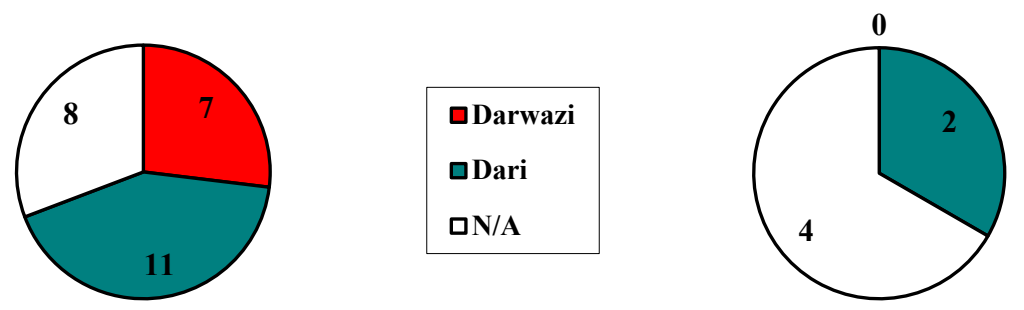

口Tangshewi
口Dari
$\square N / A$

Figure 1: Desired language of literacy in primary school

The language one would choose for children's primary education is a strong indicator of a positive attitude towards the language chosen. The majority of groups in Darwāz, and everyone in Tangshew who was in a situation to answer the question, would choose Dari. Only a few groups in Darwāz chose their local variety.

Figures 2 and 3 show to which liaisons parents would give their consent (besides a marriage with someone from their own language group).

\section{Darwaz}

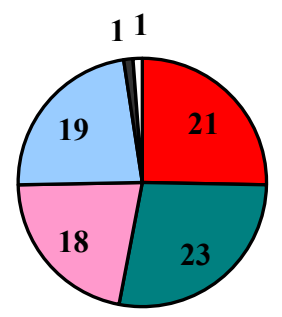

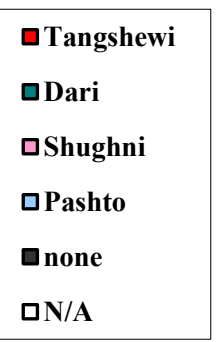

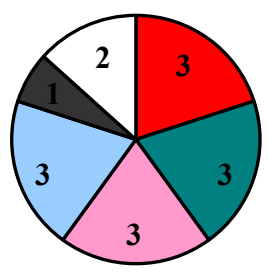

Figure 2: Acceptable marriage partner for daughters* 
Darwaz

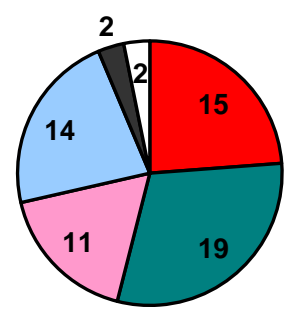

Tangshew

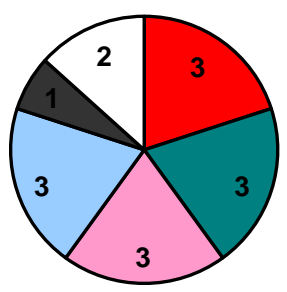

Figure 3: Acceptable marriage partner for son*

* Some respondents gave multiple answers.

People's attitude towards marriages, which cross ethnic boundaries and speech varieties can be an indicator of their attitude towards the ethno linguistic group in question. Most Darwāzi and Tangshewi parents would agree to a marriage between their son or daughter and a partner of the other speech variety, or a Dari-speaking partner. Only a few less than this would be happy to give permission for marriage with a Shughni or Pashto partner.

Figures 4 and 5 presents the language children and grandchildren will use most in the future, according to interviewees' opinions.

Darwaz

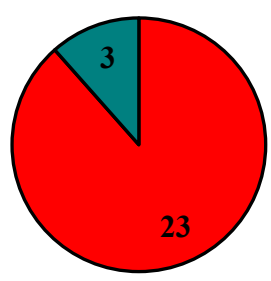

Tangshew

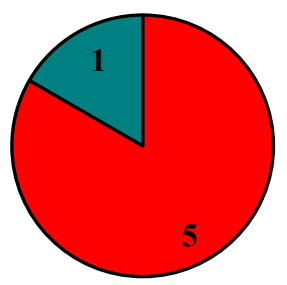

口Tangshewi

口Dari

Figure 4: Estimated language of children in the future* 
Darwaz

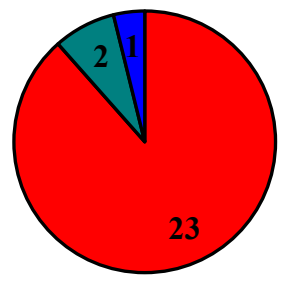

Tangshew

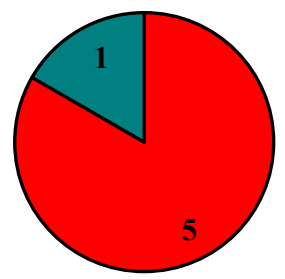

口Tangshewi

口Dari

Figure 5: Estimated language of grandchidren in the future*

* Some respondents gave multiple answers.

The majority of the Darwāzi and Tangshewi respondents feel certain that their children and grandchildren will still use their mother tongue when they are adults. They think that future generations will speak like the present one does.

In the 'Perceived Benefit' section people were asked to tell how useful they perceived Darwāzi, respectively Tangshewi, Dari, and Tajik to be in the context of finding work, higher education, communication with other communities, and gaining respect in the home community. The answers were given point values from 0 to 3: 0 indicates 'not useful', 1 means 'a little useful' or 'useful only in a limited area', and 2 stands for 'useful', and 3 is 'very useful'. The points of all respondents were averaged to reflect the Darwāzi community's views with respect to the perceived benefit of the languages in question, according to the different subjects.

Figure 6 shows the benefit the interviewed groups of men in Darwāz ascribed to the varieties Darwāzi, Dari and Tajik (Tajikistan).

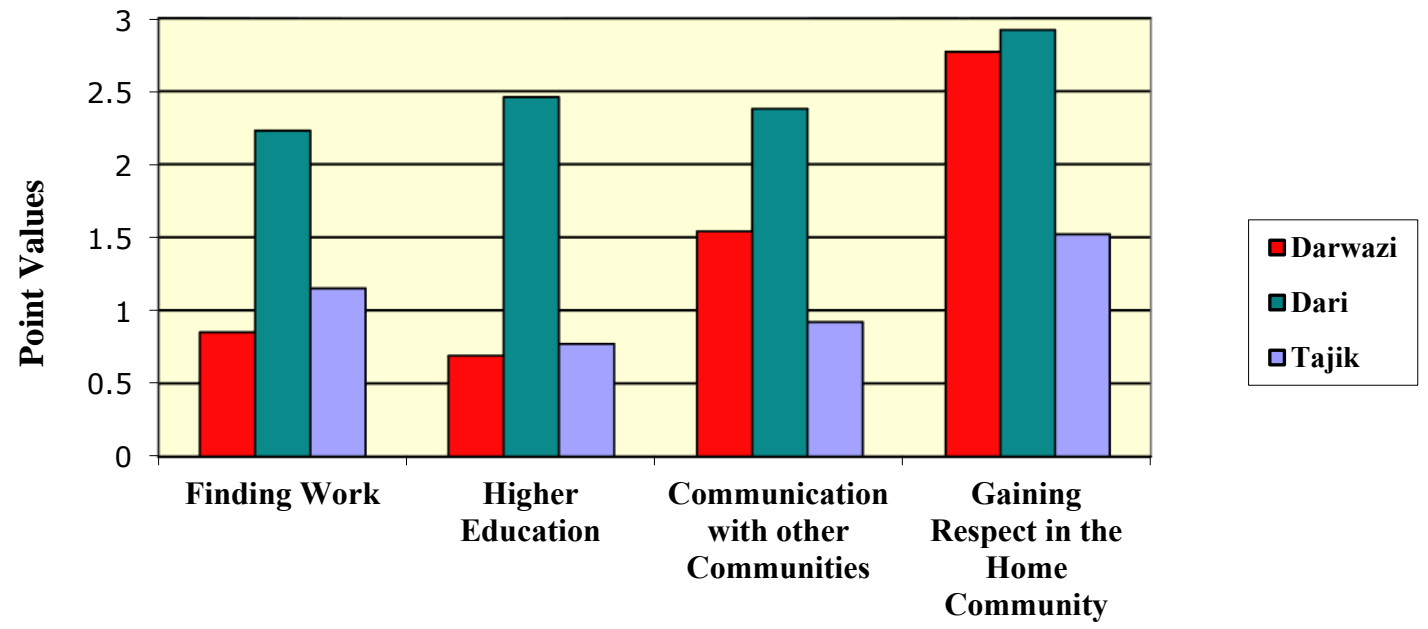

Figure 6: Perceived Benefit of Darwāzi, Dari and Tajik in Darwāz

The chart indicates that Dari is perceived as the language with the greatest benefit in all sectors of life mentioned. Darwāzi is not perceived to be useful for finding work and higher education; its usefulness for communicating with other villages is limited to Darwāzi speaking villages; 
however, it does command a high level of respect in the home village. Tajik is not considered to be very useful, although one who speaks it does gain some respect in his home village.

Figure 7 shows the benefit that the men in Tangshew view the varieties Tangshewi, Dari and Tajik (Tajikistan) to have for work, education, communication with other communities, and for gaining respect in the home community.

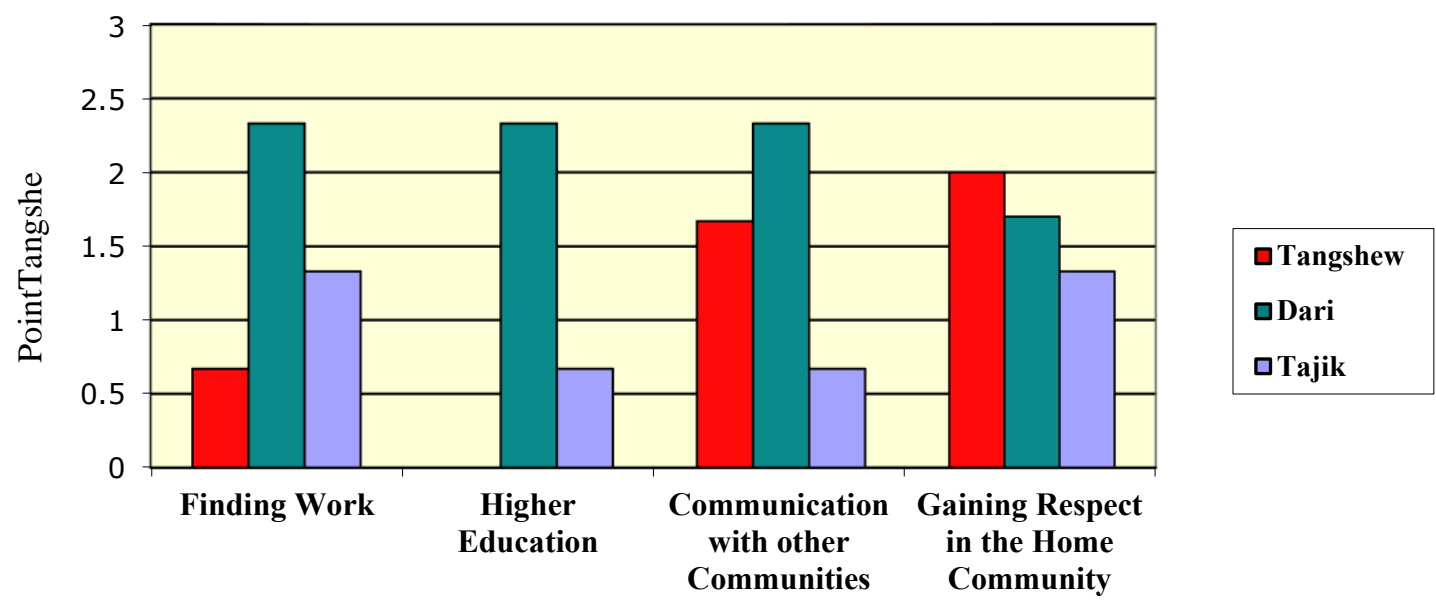

Figure 7: Perceived Benefit of Tangshewi, Dari and Tajik in Tangshew

The chart indicates that Dari is perceived by far as the most useful language in contexts outside of the Tangshew villages (finding work, higher education, communication with other communities). It also carries some respect in the home village. Tangshew is not perceived as useful for finding work and higher education, and communication in it with other villages is limited to Tangshewi and Darwāzi villages. However, it is the speech variety that gains the most respect in the home village. According to people's perception the usefulness of Tajik is limited in all sectors.

\subsection{Intelligibility between the Darwāzi villages, between Darwāzi and Tangshewi, and comprehension of Dari and Tajik}

This section presents the lexical similarity of the Darwāzi villages and Dari. It also presents the results of the Dari RTT as well as the reported intelligibility between the Darwāzi and Tangshew villages, and Dari, and Tajik.

\subsubsection{Lexical Similarity of Darwāzi varieties, and of Darwāzi and Dari}

This section presents a comparison of word lists taken in sixteen villages in Darwāz (including three in Tangshew) and of one Dari word list taken in Faizabad. Whenever possible the word lists were elicited from a mixed group, including men and women.

The lexical similarity of the Darwāzi/Tangshewi varieties and Dari is in average $82 \%$, respectively $90 \%$, depending on the tabulation. The reason for doing two calculations is that people sometimes stated they use a Darwāzi word as well as the Dari elicitation cue. Thus, the count with the Darwāzi words in these cases amounts to $82 \%$ similarity on average, and with the Dari words given to $90 \%$ on average. 
When eliciting the word lists informants often gave several words per item; they indicated that they use the Dari word given as a probe, and a different Darwāzi word as well. Therefore the lexical similarity is tabulated twice: first, including all Darwāzi words that people gave during the word list, then substituting them with the Dari words given for the same probe.

Table 5 presents the lexical similarity between the Darwāzi villages and between Darwāzi and Dari. Whenever people responded with a Dari word as well as a Darwāzi word, the latter one is used in this count.

\begin{tabular}{|c|c|c|c|c|c|c|c|c|c|c|c|c|c|c|c|c|}
\hline \multicolumn{17}{|l|}{ Jārf } \\
\hline $93 \%$ & \multicolumn{16}{|c|}{ Zengeryā } \\
\hline $85 \%$ & $87 \%$ & \multicolumn{15}{|c|}{ Jumarj-e Bālā } \\
\hline $89 \%$ & $89 \%$ & $86 \%$ & Laron & & & & & & & & & & & & & \\
\hline $87 \%$ & $90 \%$ & $84 \%$ & $86 \%$ & \multicolumn{13}{|c|}{ Nusay } \\
\hline $84 \%$ & $85 \%$ & $87 \%$ & $85 \%$ & $88 \%$ & \multicolumn{12}{|c|}{ Khizaw } \\
\hline $89 \%$ & $92 \%$ & $88 \%$ & $86 \%$ & $91 \%$ & $88 \%$ & \multicolumn{11}{|c|}{ Qala-e Kuf } \\
\hline $90 \%$ & $91 \%$ & $89 \%$ & $88 \%$ & $91 \%$ & $89 \%$ & $94 \%$ & Retow & & & & & & & & & \\
\hline $88 \%$ & $89 \%$ & $91 \%$ & $87 \%$ & $88 \%$ & $88 \%$ & $91 \%$ & $92 \%$ & \multicolumn{9}{|c|}{ Māymay } \\
\hline $85 \%$ & $86 \%$ & $91 \%$ & $86 \%$ & $89 \%$ & $95 \%$ & $90 \%$ & $91 \%$ & $92 \%$ & \multicolumn{8}{|c|}{ Darra-e Sher } \\
\hline $84 \%$ & $85 \%$ & $91 \%$ & $83 \%$ & $85 \%$ & $88 \%$ & $90 \%$ & $91 \%$ & $90 \%$ & $92 \%$ & Zanif & & & & & & \\
\hline $81 \%$ & $81 \%$ & $83 \%$ & $81 \%$ & $83 \%$ & $88 \%$ & $85 \%$ & $85 \%$ & $86 \%$ & $88 \%$ & $86 \%$ & \multicolumn{6}{|c|}{ Rezway } \\
\hline $86 \%$ & $86 \%$ & $86 \%$ & $88 \%$ & $89 \%$ & $86 \%$ & $92 \%$ & $92 \%$ & $91 \%$ & $89 \%$ & $88 \%$ & $85 \%$ & \multicolumn{5}{|c|}{ Narghaw } \\
\hline $82 \%$ & $84 \%$ & $88 \%$ & $81 \%$ & $87 \%$ & $89 \%$ & $88 \%$ & $89 \%$ & $88 \%$ & $89 \%$ & $89 \%$ & $88 \%$ & $88 \%$ & \multicolumn{4}{|c|}{ Ghumay } \\
\hline $99 \%$ & $79 \%$ & $84 \%$ & $83 \%$ & $83 \%$ & $85 \%$ & $85 \%$ & $86 \%$ & $86 \%$ & $88 \%$ & $88 \%$ & $88 \%$ & $89 \%$ & $93 \%$ & Warw & & \\
\hline $78 \%$ & $79 \%$ & $81 \%$ & $80 \%$ & $83 \%$ & $79 \%$ & $83 \%$ & $82 \%$ & $85 \%$ & $82 \%$ & $84 \%$ & $85 \%$ & $86 \%$ & $89 \%$ & $87 \%$ & Ubagh & \\
\hline $73 \%$ & $75 \%$ & $78 \%$ & $79 \%$ & $79 \%$ & $79 \%$ & $80 \%$ & $81 \%$ & $81 \%$ & $81 \%$ & $83 \%$ & $83 \%$ & $85 \%$ & $87 \%$ & $93 \%$ & $95 \%$ & Dar \\
\hline
\end{tabular}

The lexical similarity among the Darwāzi varieties spoken in the different villages is $86 \%$ on average, ranging between 78\% (Jārf and Ubaghn) and 99\% (Jārf and Warw).

Including all Darwāzi words that were mentioned, the lexical similarity of the Darwāzi varieties and Dari is, on average, $82 \%$, ranging from $73 \%$ (Jārf) to $95 \%$ (Ubaghn). It is noticeable that the percentages are quite diverse in a way that seems random. The villages in table 6 are not ordered by geographical location but lexical similarity. Thus, the percentages suggest that villages geographically close are not the most lexically similar. However, these differences between geographically close villages might be due to the different groups of respondents. For example, in Warw, the word list was taken from a group of middle-aged, educated men, well versed in Dari and proud of it. In Zengeryā, while we were eliciting the word list, the men said to each other, "Say the women's talk!" This accounts for some of the differences. Men tend to use less Darwāzi words, substituting them with Dari words, or using both words interchangeably. In several villages people explained that women use more what they called "local dialect words" (Darwāzi words). In some cases, when a Darwāzi word was asked for, another Dari word was given, e.g. for the Dari word [xo'num] 'wife', most Darwāzi villages use [zan] which is 'woman' in Dari. In Darwāzi it is used for 'woman' and for 'wife' as well. In some villages people tended to give more Dari words, while in other villages people gave the Darwāzi words as both are used alongside each other. This explains the relatively broad range of percentages which seems in conflict with speakers' unanimous claims to easily be able to understand each other. 
To give another angle on this situation, table 6 presents the lexical similarity of the Darwāzi villages and Dari, this time substituting the Darwāzi words with the Dari words in the cases where they were reported to be used.

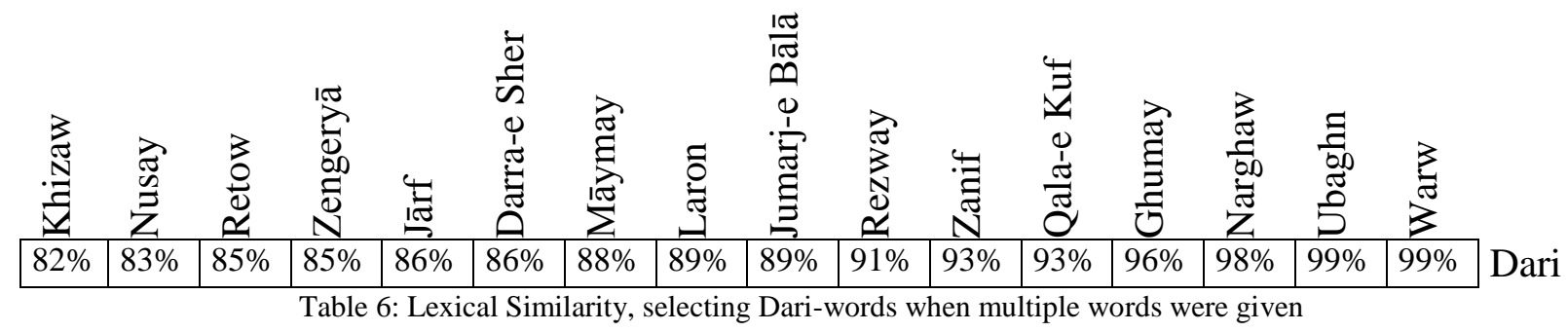

The lexical similarity of the Darwāzi and Dari word lists is on average $90 \%$ when all Dari words that were given are included. The percentage ranges between $82 \%$ (Khizaw) and 99\% (Warw). Darwāzi words tend to be used by women and young children while men use more Dari words due to their increased exposure to the Dari language.

However, high lexical similarity between two speech varieties does not necessarily coincide with a high degree of intelligibility, because, according to Casad (1991) "the set of variables that underlie linguistic similarity are largely distinct from those that underlie intelligibility". According to Bergman (1990), lexical similarity less than about $70 \%$ generally indicates the presence of different languages; if the similarity is more than $70 \%$, dialect intelligibility testing is needed to determine how well people can understand the other speech form. Blair (1997) even writes that if word lists indicate a lexical similarity below $60 \%$ the speech varieties are "different languages" and no intelligibility testing is necessary. Above $80 \%$, Blair writes, speech varieties are very similar; they might be very similar dialects of one language if the inherent intelligibility is high. A lexical similarity of $90 \%$ between Dari and Darwāzi (including all Dari words) seems to indicate the presence of closely related varieties and would make dialect testing superfluous; however, a lexical similarity of $82 \%$ including all Darwāzi words makes intelligibility testing desirable.

Between Dari and Darwāzi numerous regular sound changes take place. This is e.g. a change from [o] to [u], like in [xo'na] to [xu'na] house, and [non] to [nun] bread; as well as a change from [u] to [y], like in [du:r] to [dy:r] far, [xur ka'dan] to [XYc ka'dan] cut into pieces, [dut] to [dyt] smoke, and [ustu'xon] to [Ystə'yon] bone. Besides this, there is a regular grammatical

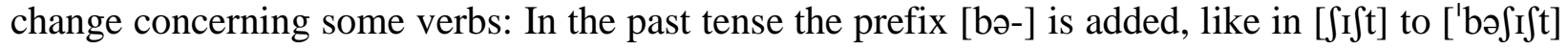
he sat down, [raft] to ['bəraft] he went, and [di:t] to ['bedi:t] he saw. All changes mentioned were not given unanimously in all villages.

\subsubsection{Intelligibility of Dari using Recorded Texts}

For the Recorded Text Testing a Dari story recorded in Faizabad was used. After the RTT was administered, interviewees were asked about their contact with Dari-speakers, e.g. whether they travelled to Faizabad or other Afghan cities, whether they received guests from there, whether they listened to the radio regularly, or whether they had lived in a Dari-speaking area for any length of time. According to their answers, the numbers 1 (none, or almost no contact), 2 (little and irregular contact), 3 (regular contact), or 4 (lived in a Dari-speaking area) were assigned (see 'Appendix D: Stories for RTTs'). School education was also taken into account, because 
schoolbooks are in Dari; especially beyond grade 4 students start to read fluently and most teachers use Dari as the language of instruction. The average percentage scored in the Recorded Text Testing was $74 \%$, with the lowest score being $41 \%$ and the highest $100 \%$.

Figure 8 presents the result of the RTTs. The results are given according to the amount of language contact the subjects have had with Dari-speakers.

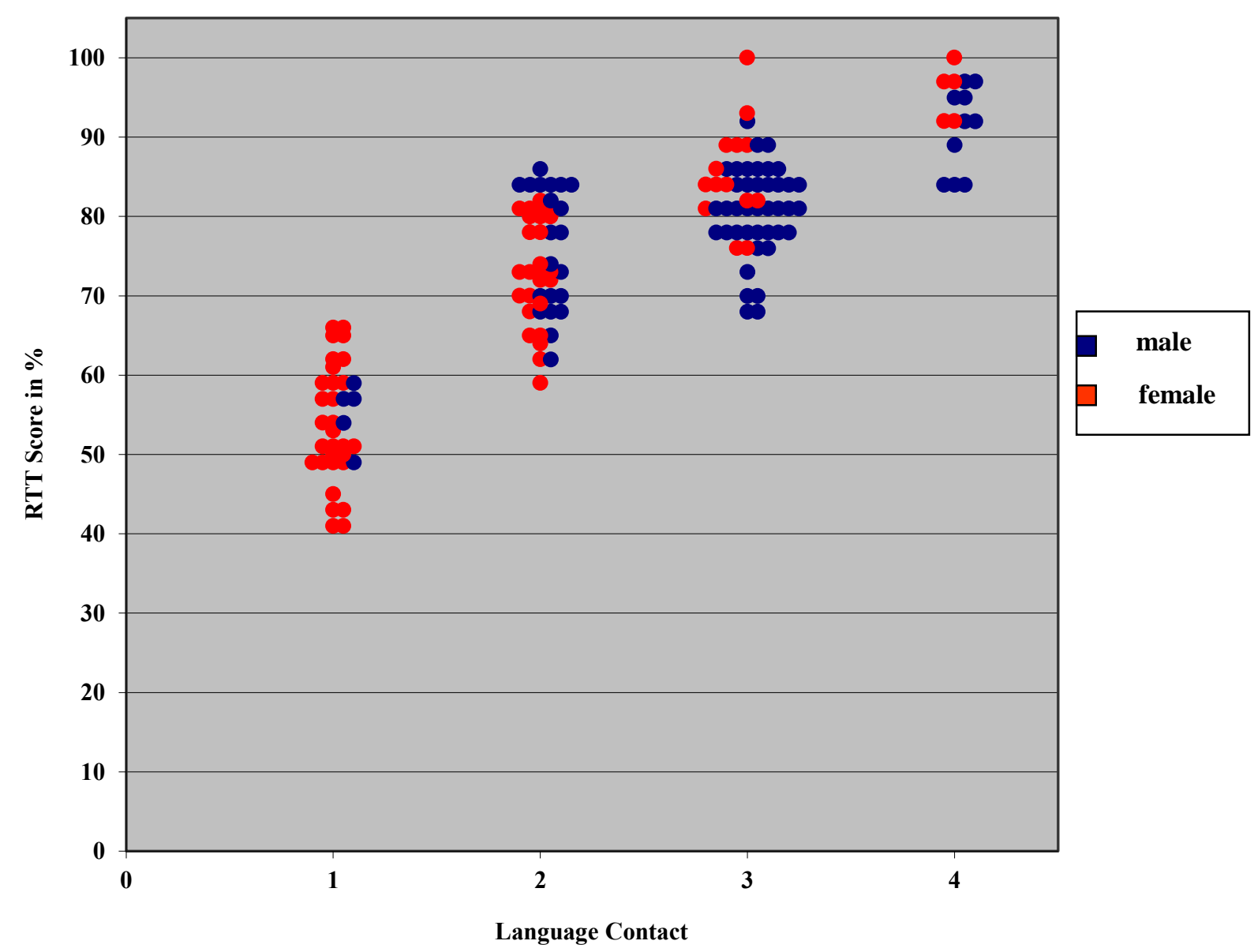

Figure 8: RTT results in relation to language contact

The chart shows that contact with Dari-speakers is a major influence on RTT scores. The range of scores reflects a combination of inherent and acquired intelligibility of Dari: levels of inherent intelligibility are shown in the results of those with low contact with Dari, and the scores of those with higher levels of contact reflect various levels of comprehension (i.e. acquired intelligibility). The average score of subjects with contact level 1 is $54 \%$, with contact level 2 it is $73 \%$, with contact level 3 it is $82 \%$, and with contact level 4 it is $92 \%$. The average of all subjects is $74 \%$. The different scores of subjects with approximately the same level of contact are the result of other factors, like concentration or distraction during the test. Some subjects said after the RTT that they had difficulties concentrating because they have taken naswār (a kind of sniff tobacco).

The following four tables show the RTT results again. The results are displayed according to gender, then according to gender and age, then according to gender and home village, and finally according to gender and school education. 
Table 7 gives the RTT results according to gender, also with the highest and lowest results scored of the two population segments.

\begin{tabular}{|l|l|l|l|l|}
\hline \multicolumn{2}{|l|}{ Criterion } & lowest score & highest score & average score \\
\hline \multirow{2}{*}{ Gender } & male & $49 \%$ & $97 \%$ & $\mathbf{7 8 \%}$ \\
\cline { 2 - 5 } & female & $41 \%$ & $100 \%$ & $\mathbf{6 9 \%}$ \\
\hline
\end{tabular}

Table 7: RTT results according to gender

The RTT results show a clear gender-related pattern. This is because men travel far more than women do. Of most families at least one man will travel regularly to Faizabad, once or twice yearly for 10 to 20 days at a time. He obtains the household supplies for the whole family. When guests from other areas visit, it is the men of the village who talk to them. Women have far less contact to Dari speakers. Most women listen to radio programmes in Dari, but only occasionally. They only travel to the city when they are sick, and a male family member accompanies them and is usually the the one to interact with the Dari-speaking doctors. Additionally, when women travel to the city to visit family members, e.g. a daughter who married a man living there, they speak Darwāzi to the extended family.

Table 8 gives the RTT scores according to gender and age, it also indicates the highest and lowest scores for each segment.

\begin{tabular}{|l|l|l|l|l|l|}
\hline \multicolumn{2}{|l|}{ Criterion } & lowest score & highest score & average score \\
\hline \multirow{2}{*}{$\begin{array}{l}\text { Gender } \\
\text { \& Age }\end{array}$} & male & under 30 & $49 \%$ & $92 \%$ & $\mathbf{7 7 \%}$ \\
\cline { 2 - 6 } & over 30 & $51 \%$ & $97 \%$ & $\mathbf{7 9 \%}$ \\
\cline { 2 - 6 } & female & under 30 & $41 \%$ & $100 \%$ & $\mathbf{6 8 \%}$ \\
\cline { 2 - 5 } & over 30 & $42 \%$ & $100 \%$ & $\mathbf{6 7 \%}$ \\
\hline
\end{tabular}

Table 8: RTT result according to gender and age

As the table indicates, age hardly influences the RTT score. Older people have had more of a chance to relate to Dari-speakers, and older men have been on more journeys outside Darwāz. Nevertheless, the younger people have benefited from (at least some years of) school education and therefore have been exposed to written Dari in school books. Therefore the average of old and young subjects' result is similar.

Table 9 gives the RTT results according to gender and home villages of the subjects. It also gives the highest and lowest results for both genders in each area.

\begin{tabular}{|l|l|l|l|l|l|}
\hline \multicolumn{2}{|l|}{ Criterion } & lowest score & highest score & average score \\
\hline \multirow{2}{*}{\begin{tabular}{l} 
Gender \\
\multirow{3}{*}{\begin{tabular}{l} 
Village \\
\multirow{4}{*}{}
\end{tabular}}
\end{tabular}} & male & Tangshew valley & $49 \%$ & $92 \%$ & $\mathbf{7 2 \%}$ \\
\cline { 2 - 6 } & East (to Nusay) & $49 \%$ & $97 \%$ & $\mathbf{7 6 \%}$ \\
\cline { 2 - 6 } & West (from Nusay) & $59 \%$ & $97 \%$ & $\mathbf{8 1 \%}$ \\
\cline { 2 - 6 } & female & Tangshew valley & $50 \%$ & $97 \%$ & $\mathbf{7 2 \%}$ \\
\cline { 3 - 6 } & East (to Nusay) & $41 \%$ & $100 \%$ & $\mathbf{7 3 \%}$ \\
\cline { 2 - 5 } & West (from Nusay) & $43 \%$ & $100 \%$ & $\mathbf{6 3 \%}$ \\
\hline
\end{tabular}

Table 9: RTT results according to gender and home village

The home village of the subject influences the RTT result to some extent. Men's scores are lowest in the Tangshew valley due to its isolation. The villages there are even poorer than most other Darwāzi villages and therefore men travel less frequently and stay for shorter periods of 
time in Faizabad and other Afghan cities. Also, they do not send men to Iran for work, therefore they are less exposed to other varieties; this also perpetuates the relative poverty of these villages and keeps trips to cities to a minimum. Besides this, almost all in men in Tangshew use naswär, and many said that they therefore had difficulties concentrating on the RTT story, reducing their scores. The western villages tend to receive more visitors in the form of traders and others from Tajikistan and Afghan cities. Men from there also travel to Afghan cities and to Iran more regularly. The reason for this might be that the end of the road in Qala-e Kuf/Kufāb is slightly closer to the western villages than the end of the road in Rubāt/Roshān is to the eastern villages.

The average result for women from Tangshew and the eastern villages is similar; in the western villages the average is lower. Besides Nusay, fewer women in the western villages have had school education, they travel less and have less contact with guests. Another reason might be that the western villages are almost all Sunni villages, while almost all of the eastern villages are Ismaili. There women are more exposed to Dari speakers since more latitude is allowed to them.

Table 10 gives the RTT results according to gender and the school education the subject had the privilege of benefiting from.

\begin{tabular}{|l|l|l|l|l|l|}
\hline \multicolumn{2}{|l|}{ Criterion } & lowest score & highest score & average score \\
\hline $\begin{array}{l}\text { Gender } \& \\
\text { School }\end{array}$ & male & less than $5^{\text {th }}$ grade & $49 \%$ & $95 \%$ & $\mathbf{7 3 \%}$ \\
\cline { 2 - 6 } Education & $5^{\text {th }}$ grade or higher & $62 \%$ & $97 \%$ & $\mathbf{8 2 \%}$ \\
\cline { 2 - 6 } & female & less than $5^{\text {th }}$ grade & $41 \%$ & $97 \%$ & $\mathbf{6 4 \%}$ \\
\cline { 3 - 6 } & $5^{\text {th }}$ grade or higher & $59 \%$ & $100 \%$ & $\mathbf{8 1 \%}$ \\
\hline
\end{tabular}

Table 10: RTT results according to gender and school education

As the table indicates, school education beyond grade 4 influences the RTT result. Especially for women the difference between $64 \%$ (without education or education below grade 5) and $81 \%$ (with grade 5 education or higher) is major. This is because most women have no contact with Dari speakers besides school education and radio broadcasts. For men the impact of school education on the intelligibility of Dari is still noteworthy, but far less than for women because men have other opportunities to learn Dari (especially travel to or living in Dari-speaking areas).

In summary, travel patterns and school education provide the highest exposure to Dari and therefore most influence its intelligibility for Darwāzi people. For men, travel to Dari-speaking areas and living there is most significant; for women, school education makes the greatest difference.

\subsubsection{Reported intelligibility between the Darwāzi varieties, of Dari, and Tajik}

$\underline{\text { Intelligibility between different Darwāzi varieties }}$

After reporting travel patterns the interviewees were asked about the difference of the speech between their home village and other villages, and about the intelligibility of other varieties. Without exception, everyone reported that in the neighbouring villages higher up and lower down the valley, although the speech is slightly different, it can be understood without difficulty. Men who travel from east of Māymay river up out of Darwāz and people who travel from Māymay river down out of Darwāz to reach Faizabad (the farthest distances along the river), report that in every village they pass on the way the speech variety is only slightly different and that they can communicate easily with the people. Women travel to other Darwāzi villages to 
visit relatives, especially to see women who have married a man from another village. They report that on such visits they easily understand the speech variety spoken there. Also, the speech in the side valleys Kufāb, Shuriān and Jaway is easily intelligible and only slightly different to the variety spoken in the villages near the river Panj. People say they never experience any difficulties communicating in other villages in Darwāz.

Until three years ago people from the eastern villages (up to Māymay) travelled through Tangshew to reach Faizabad, which is no longer necessary since a bridge over a side river was built. People reported that they did not have any difficulty understanding the speech variety spoken in Tangshew; it is only slightly different to their own.

In the villages of Rezway und Nusay we asked about Darwāzi words that we had heard in villages further up the river. People could understand the meaning of each word, even though they said they use different words in some instances.

\section{Intelligibility of Dari and Tajik}

After listening to the RTT story $86 \%$ of the subjects said that they had been able to understand it completely. $9 \%$ said they had been able to understand most of the story while $5 \%$ reported that they understood some or very little of the story.

As part of the Sociolinguistic Group Interview, people were asked how much they understand Dari and Tajik. They were asked to specify how much older men, and older women, adult men, and adult women, and children understand of these two varieties. In both, the male and the female groups, usually older and younger people were present and people reported concerning their own understanding of the two speech varieties as well as others' living in the village. Parents reported about their own and others' children's comprehension of Dari and Tajik. Responses to questions of intelligibility were given values between 0 and 3 , that is 0 for 'not at all', 1 for 'some of it', 2 for 'most of it', and 3 for 'all of it'. The responses of the male and female groups of all villages were averaged out.

Figure 9 shows the result of the average of the reported intelligibility of Dari and Tajik.

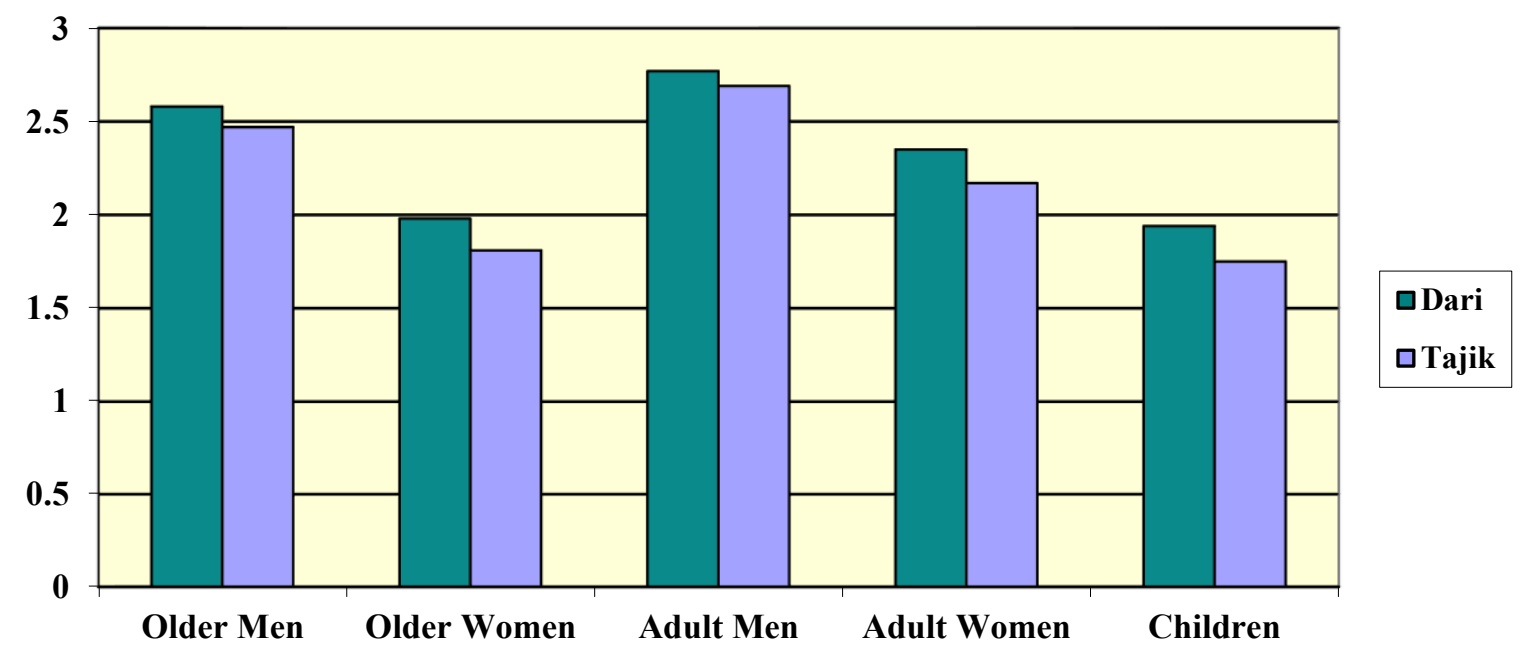

Figure 9: Reported intelligibility of Dari and Tajik 
Throughout all subdivisions of the population, people report that they understand Dari slightly better than Tajik. Older men and adult men claim to understand nearly everything when they listen to Dari or Tajik speakers. Older women understand most of Dari and Tajik speech, and adult women a little more. Children understand slightly less than older women. They have had the least time to be exposed to other varieties besides their own. Some groups remarked that children attending school understand more Dari than children who do not attend school. This was also occasionally mentioned in regard to Tajik, even though Tajik is not taught in school.

The groups were also asked what they found easier to understand, Dari or Tajik. As people listen to Dari and Tajik programmes on the radio and TV, they can compare directly, even though some have very little contact to Dari and Tajik speakers.

Table 11 shows the language the interviewees find easier to understand, Dari or Tajik.

\begin{tabular}{|l|l|l|l|}
\hline & Dari & Tajik & the same \\
\hline L easier to understand & 20 & 5 & 7 \\
\hline
\end{tabular}

Table 11: Language easier to understand

Here the vast majority answered with Dari. This is surprising, as according to people's reports the intelligibility of Dari is only slightly higher than that of Tajik. The fact that the attitude towards Dari is more positive than towards Tajik might come into play here. Besides this, the villages farther inland from the boundary river to Tajikistan (which are the three Tangshew villages, and Warw, Ghumay and Qala-e Kuf) have less contact with Tajik people. In these five villages the answer was mostly Dari; except that two of the ten groups interviewed answered with "the same". The fact that in these villages the groups still reported a relatively high intelligibility of Tajik can be explained by their contact with Tajik through Tajik radio and TV programs, frequently listened to by all segments of population except young children.

\subsubsection{Summary}

The lexical similarity of Darwāzi and Dari is 82\% with all Darwāzi words given; it is $90 \%$ including all Dari words given. Even though both numbers are well above the "differentlanguage threshold" of $70 \%$ lexical similarity, intelligibility testing seemes desirable.

Recorded Text Testing conducted with a Dari story resulted in subjects with none or almost no contact (mainly women without school education) achieving an average of 54\%. The average score of people with all levels of contact was 74\%. The results of subjects with contact level 1 (none or almost no contact) indicates inherent intelligibility of the two speech varieties. However, people are extensively exposed to Dari and at the current time almost all children, boys and girls, attend school. As they are the future adult generation, the intelligibility of Dari is likely to increase in a major way.

People report that they can understand all varieties of Darwāzi without any difficulties. They also report that all segments of the population have a good, if not complete understanding of Dari; adult men understand Dari completely.

\section{Discussion}

The following discussion of vitality, attitude, and intelligibility aims to evaluate the findings described in the result section. The discussion relates back to the objective (see '4.2 Objective') 
and to the research questions (see '4.3 Research Questions'). Again, the objective and the research questions are:

\section{Objective}

The objective of this linguistic assessment was to find out whether the Darwāzi people can be adequately served with primary school education and literacy programs in Dari, or whether they would benefit from language development in their own speech varieties. If the latter is applies, (a) can the Tangshew people be served with the same material, and (b) might an adaptation of Tajik material be possible?

\section{Research Questions}

1. Living conditions: What basic information can we find out about the people groups living in Darwāz (location, population, living conditions, education, infrastructure etc.)?

2. Vitality: What is the long term perspective on the vitality of the Darwāz speech varieties?

3. Attitude: What attitudes do the Darwāzi and the Tangshew people have towards their own vernacular, each other's variety, towards Dari, and Tajik?

4. Intelligibility: To what extent are Dari and Tajik intelligible to the Darwāzi people? Are the varieties of the different villages mutually intelligible?

Answers to 1 'Living Conditions' are found in '3. Background Information concerning the Darwāz area'.

\subsection{Vitality of Darwāzi}

The objective of this linguistic assessment is linked with the vitality of Darwāzi. In case Darwāzi is not a speech variety with a high degree of vitality, the development of educational and literacy material might not be needed. The results of the assessment showed that the vitality of Darwāzi is complex - in some ways it seems to be strong, but in others vitality is certainly low.

In the article Indicators of Ethnolinguistic Vitality Landweer gives eight factors that indicate the vitality of a language. In a similar way they seem to apply to a speech variety closely related to the lingua franca, as Darwāzi (including Tangshew) is to Dari. These factors are: 1. Relative position on the urban-rural continuum; 2. Domains in which the language is used; 3. Frequency and type of code switching; 4. Population and group dynamics; 5. Distribution of speakers within their own social networks; 6. Social outlook regarding and within the speech community; 7. Language prestige; and 8. Access to a stable and acceptable economic base (Landweer 2000). Concerning Darwāzi some of these factors give significant clues regarding its vitality.

Concerning factor 1, 'Relative position on the urban-rural continuum', Landweer claims that a language located within urban confines would be more affected by other languages and thus would be weaker than a language remote from an urban community of other-language speakers. The latter applies to Darwāzi; the Darwāzi people group is secluded from the outside world. Access to Faizabad, the nearest Dari-speaking town, requires long and expensive travel. From some villages it takes more than two weeks to get to Faizabad, especially in winter. Therefore with regard to the urban-rural continuum, at the present time the vitality of Darwāzi fares well. Looking into the future, however, the government, with the help of aid organisations, plans to 
build a motor road through Darwāz, which is eagerly anticipated by the people. This will make access to the Darwāzi villages much easier and faster, although it will only be possible to use this road during the summer months. According to this indicator future road access diminishes the vitality of Darwāzi.

Factor 2, 'Domains in which the language is used', means that the fewer domains the vernacular occupies, the lower its vitality. Landweer considers the domain of the home to be the foundational domain. The vitality of the vernacular is high if it is used at home, for cultural events, social events, and in other domains. In Darwāz all children in the community learn Darwāzi as their first and only language until they start school. Darwāzi is the language of the home and community domains. Within the village the Darwāzi use Dari only with visitors. Nevertheless, Dari is used in a number of domains where it is spoken frequently (travel and trade, media and administration) or as a formal language (education and religion men especially use Dari in the domain of travel and trade. Even though these are secondary domains this is a threat to the vitality of Darwāzi.

Presently, women have less access to the secondary domains than men, they travel less and do not have contact with government officials; nevertheless, most girls attend school now and many listen to the radio. Since regular school education for children has been implemented in most villages almost all children go to school for at least some years. There they acquire Dari as most teachers use it form $3^{\text {rd }}$ grade, using an increasingly higher register in the following grades. Many women regularly listen to the radio, some have also TV. Even though women only have access to the education and media domains, young women do learn Dari to a certain degree. People in Zanif are aware that older illiterate women use more words of the Darwāzi speech variety, while young women who went to school use them less. In Zengeryā people are aware of the difference of men's and women's speech. Asked about Darwāzi words, one man said to another: "Say the words that women use."

Concerning factor 4, 'Population and group dynamics,' Landweer writes that for a language to be vital a critical mass of speakers is crucial. The number of speakers necessary varies according to context. Darwāz has a population of 95000 people, this is more than the population of some minority languages in Badakhshan with high vitality (e.g. Wakhi, about 12000 and Sanglechi, about 3000). However, the number is not the main component of this indicator. For a language to be vital a core of fluent speakers is necessary. It is crucial how the group of speakers is impacted by the language characteristics of immigrants who have come to live among them. A few men from aid agencies, like doctors for the clinics, have moved to Darwāz. They are from other parts of the country and speak Dari. The Darwāzi men use Dari with them. However, the women, who come from outside and get married to Darwāzi speaking men, acquire the Darwāzi speech variety and adopt it for themselves. Men and women who come from outside to live in Darwāz are few. The implication here for the vitality of Darwāzi is neither positive nor negative, but rather neutral.

Factor 6 'Social outlook regarding and within the speech community' means that strong ethnic identity can influence language choice. The perception a group has of itself can support or undermine the value associated with the language and the use of the language. According to Landweer, the crucial question is: "Is there internal and/or external recognition of the language community as separate and unique within the broader society?" The Darwāzi speech variety is neither internally nor externally recognized. In villages adjoining the Darwāz area people say that the Darwāzi speak Dari, just a bit differently. The Darwāzi people themselves also claim to speak Dari and only after some probing they explain that they speak "the dialect of Darwāz". The 
many women who have not been outside the Darwāz area are often not aware that their speech variety is different to those spoken in other parts of Badakhshan. There is no pride or sense of identity in being Darwāzi; people predominantly perceive themselves as poor and in need of material help. This situation does not indicate high vitality of Darwāzi.

Factor 8, 'Access to a stable and acceptable economic base' seems to be crucial for this discussion. People adopt a language because they perceive it as economically beneficial. The statements concerning the perceived benefit of Darwāzi and Dari showed that for finding work Dari is perceived as useful or even highly useful, while Darwāzi is perceived as 'only a little useful' or even 'not useful'. As harvests are poor, travel has become more and more essential for people to secure their survival. Men frequently travel to Faizabad, where they are exposed to and speak Dari. This has been changing the men's language and is likely to change it even more in the future. Confirming this, in Retow people reported: "Now many travel to Faizabad. Therefore our language has become more like other parts of Badakhshan." In Narghaw people said that men who go to the bazaar in Faizabad on a regular basis modify their language. They added that this would gradually influence the language of the village community back in Darwāz as well. In Zengeryā people said concerning the future: "Children speak the local dialect at home, but when they grow older and travel to town their language will change." They also mentioned the frequent travel to Iran: "When men go to Iran to work there they have to adjust their speech. Otherwise they will be recognized as Afghans and sent home."

In summary, it is likely that the use of Darwāzi will decline very slowly, over several generations. A man in Retow predicted: "I learned the language of my grandfather, but now the language has changed." The people report that the old generation speaks differently from the middle generation and the young generation again speaks differently. In Narghaw the researchers named some dialect words they had heard in other villages. The people said that these words had been used in the old days but are now not used any more. In Qala-e Kuf (the village where the motor road starts) a man said that their local language is disappearing. He said to the researchers (who spoke Dari): "Now we talk more like you are talking."

\subsection{Attitudes towards Darwāzi, Dari and Tajik}

As the data in the results section indicates, the attitude towards Darwāzi (including Tangshew) is indifferent and somehow ambiguous. Dari is viewed very positively. The attitude towards Tajik is between indifferent and negative.

When people were directly asked for their opinion of their language, they said that their vernacular is a good one and they like it very much. A third of all groups that commented on the subject agreed that they would prefer their children to become literate in Darwāzi and would like to have books in Darwāzi themselves. Almost everyone expects their children and grandchildren to speak Darwāzi when they grow up and everyone professed to be happy about that fact.

However, although positive attitudes towards Darwāzi were expressed, a number of comments made it obvious that the Darwāzi people perceive their speech variety as inferior to Dari. In Darra-e Sher the researchers named Darwāzi words they had learned in previous villages and asked whether people understand and use them as well. The people responded by laughing about the words; they seemed to be embarrassed by them. In the same village, while eliciting the word list, the group talked about words used in the local valley compared to words used in the city. Some people commented that the (Dari) words used in the city are better. Likewise in Warw people said that they want their language and culture to improve, therefore they prefer to use 
Dari. In Ghumay the people commented that Darwāzi was an ancient language and that it was from the village. Likewise, in Jārf the people claimed that their speech was an old and simple language. In the school in Māymay, while talking to the male teachers, the head teacher insisted with vehemence that in his village people speak Dari, not speak a dialect (as another teacher had told us). According to his definition, the difference between a dialect and a language is that a language has a written form while a dialect does not. In school the teachers and children use the written form of Dari, as everyone literate does for writing; therefore, according to him, people do not speak a dialect in the village. In Laron when the researchers used Darwāzi words they had learned in previous villages, the people responded that these were words used in the villages further up the river, it seemed they wanted to distance themselves from dialect words. But taking the word list it became clear that these words were used in Laron as well. Through these comments people expressed a negative attitude towards their vernacular.

When asked what language is spoken in the village, people usually first answered with Dari or Farsi. Only when further probed they came up with different names, or rather explanations and descriptions for their speech variety, like "local dialect" or "the dialect of Darwāz" (see '2.3 Language classification'). The fact that people do not have a unifying name for their speech variety indicates that there is no special awareness of the vernacular. Many people display an indifferent attitude towards their speech variety, no positive attitude or pride.

The attitude towards Dari is very positive. Two thirds of the groups who commented on the subject like seeing their children literate in Dari, as they are now. Almost everyone would permit their children to marry a Dari-speaking spouse, the only objection being that it is too far for their daughters and they would become homesick. In fact already many parents have married their daughters to Dari-speaking men living in one of the towns of Badakhshan. People perceive Dari as being very useful for finding work, for higher education, and for communication with other villages. Likewise, Dari is seen as more useful than Darwāzi for gaining respect in the home village even though it is not needed for communication there. Dari is considered the language of the city and the language of progress and success. The Darwāzi people's attitude towards Dari is very positive.

Attitudes towards Tajik range from indifferent to negative. Tajik is perceived as only a little useful in the areas of work, education, and communication with other communities. Surprisingly Tajik is perceived as useful by some people to gain respect in the home community. This might be because people who understand Tajik are those who communicate with the Tajik engineers who occasionally come to some villages to survey the terrain for the eagerly anticipated street building project. Besides this, most people choose to listen to Tajik radio and a few rich households watch Tajik television.

However, many complain that Tajik people do not help them in their daily struggle and therefore they can not be good people. The people in the villages at the bank of the Panj river have the paved road, frequented by cars and trucks, and poles for the electricity lines, constantly before their eyes. This provokes envy in the Darwāzi people and enhances a negative attitude towards Tajik. The men in Ubaghn spelled out what other people only suggested cautiously: "The Tajiks are not good people; they are our neighbours but they do not help us." Tajik achieved the lowest result in the 'Perceived Benefit' section. People are of the opinion that Tajik is not useful in Afghanistan, however, it can be understood since it is very close to Dari and to Darwāzi.

If there were a choice to be made between using an adaption of Tajik primary school literature and reading material or Dari literacy material in Darwāz, Dari should be chosen. This is 
because attitudes towards Dari are more positive than those towards Tajik, and for the Darwāzi people Dari is easier to understand than Tajik (see '6.3.3 Reported intelligibility between the Darwāzi varieties, of Dari, and Tajik'). As an adaptation of Tajik into Darwāzi is not a suitable option, it will not be discussed further in the following sections.

\subsection{Intelligibility of Dari}

The lexical similarity between the varieties of Darwāzi spoken in the different villages is $86 \%$ on average and people uniformly report that they understand each other's variety without any difficulty (see '6.3.1 Lexical similarity of Darwāzi varieties, and of Darwāzi and Dari' and '6.3.3 Reported intelligibility between the Darwāzi varieties, of Dari, and Tajik). This includes the villages in the Tangshew valley. However, the question of the intelligibility of Dari remains, as does that of whether Dari is suitable for literacy and school education in primary schools.

According to self-reported information, most people understand Dari well. Adult men understand the most Dari: they understand nearly everything. Older women and children understand the least: about half of what is said to them. Older men and adult women are somewhere in between: they understand most of what is said in Dari but not everything.

The reported information roughly matches up with the results of the RTTs. The average result of people with contact level 1 is $54 \%$, this segment predominantly consists of women who have not been travelling and have not had the chance to benefit from school education. The average result of people with contact level 4 is $92 \%$; these are mainly men who have had regular contact with Dari speaking people through travel or an extended stay in a Dari-speaking area. The average result of all subjects is $74 \%$. According to Blair, generally test results over $80 \%$ are considered high and under $60 \%$ low (Blair 1997). Grimes writes that test results lower than $70 \%$ indicate the presence of different languages. Results higher than $85 \%$ indicate good communication between the speech varieties and the presence of one language (Grimes 1997). He continues that a result between these two numbers indicates marginal intelligibility. A noteworthy result of the RTT tests is that people who have had very little contact with Dari speakers achieved a much higher result if they attended school for several years. Presently, children of both genders attend at least primary school. They seem to acquire Dari within a relatively short time as teachers usually start using Dari in grade 3 and gradually use it more in higher grades; also the school books are written in Dari. When the present student generation grows up they (both boys and girls) will be able to understand Dari well. The multiple regular sound changes between Dari and Darwāzi (see '6.3.1 Lexical Similarity of Darwāzi varieties, and of Darwāzi and Dari') also indicate that it is possible to acquire Dari quite rapidly after a brief time of getting used to it. For these reasons the Darwāzi people will probably acquire understanding of Dari in the future generations.

It is also likely that lexical similarity of Dari and Darwāzi will increase as people tend to use more Dari and less Darwāzi words. Presently, men use more Dari words than women do, as they are more exposed to Dari. It is to be expected that in future when more women have the chance to benefit from education, they will increasingly use Dari vocabulary as well. Therefore, inherent intelligibility is likely to grow as well as acquired intelligibility, as the Darwāzi increasingly include more Dari words and forms in their speech. A reflection of this will be a higher lexical similarity between the two speech forms.

Even though presently the degree of intelligibility of Dari to the Darwāzi people varies greatly among the different segments of population, for example men understanding much more 
Dari than women, there seems to be a clear tendency that in the years to come the number of people who understand Dari well will increase gradually. Taking these factors into consideration, it is apparent that the potential for gradual language shift, away from Darwāzi, to Dari, should not be ignored.

\section{Recommendation}

Considering the data outlined in this report, we recommend that a language development programme in the speech variety of Darwāzi not be started, but rather that Dari continue to be used for school books and for adult literacy classes.

This recommendation is primarily based on two factors: the Darwāzi people's language attitudes, and language vitality. First many of the Darwāzi people would not want and appreciate such a programme. In general the Darwāzi people hold a neutral attitude towards their vernacular, while in some villages they even expressed a negative attitude. The Darwāzi people do not view their speech variety as a separate language; this is indicated by the fact that they do not have a separate name for it but call it a lahja-e dari 'dialect of Dari'. Second, in the future the comprehension of Dari is likely to increase in a major way while the use of Darwāzi is likely to decline. Contact with Dari speakers in the cities is increasing as there are hardly any opportunities for work in Darwāz; besides this, road access to Faizabad is feasible in a few years' time. Already now, men are getting used to Dari and are speaking it in their village. Elderly women are the ones who speak most Darwāzi. It is likely that the use of Darwāzi will decline in the future.

The number of children attending school has been growing in significant numbers over the previous ten years. Therefore the majority of the future adult generation will be literate. Teachers use Darwāzi in school in lower grades and change to Dari (first the variety spoken in cities, like Faizabad or Kabul, then higher, written Dari) in higher grades. Children acquire Dari in school through a process of slowly getting accustomed to it, without having major disadvantages compared to children of parents who speak the variety of Dari used in Faizabad or Kabul. People do not depend on the development of their vernacular into a written form for school education, they are able to benefit from the teaching already offered in Darwāzi and Dari, and from the written educational material in Dari

\section{Acknowledgements}

We sincerely thank the provincial and district representatives of the government who supported our research effort. Thank you also to Bärbel and Martin Beck who helped to gather the linguistic data during a research trip to the Darwāz area.

\section{References}

afghana! web directory. 2008. http://www.afghana.com/GetLocal/Afghanistan/Provinces.htm. Last accessed December 20, 2008.

AIMS. 2008. Estimated Population North East Region Afghanistan. Afghanistan Information Management Service (AIMS). http://www.aims.org.af/maps/national/regions/ne estimated population.pdf. Last accessed September 24, 2008. 
----- 2007. North East Region Afghanistan. 2004. Afghanistan Information Management Service (AIMS).

http://www.aims.org.af/maps/national/political_divisions/north_east_region_map.pdf. Last accessed September 24, 2008.

-----. 2004. Darwaz District. 2004. Afghanistan Information Management Service (AIMS). http://www.aims.org.af/maps/national/regions/darwaz.pdf; Last accessed September, 24, 2008.

Bergman, T. G. (ed.) 1990. Language Assessment Criteria. Survey Reference Manual. Dallas: Summer Institute of Linguistics.

Blair, Frank. 1997. Survey on a Shoestring. Dallas: Summer Institute of Linguistics.

Casad, Eugene H. 1974. Dialect Intelligibility Testing. Norman, Oklahoma: Summer Institute of Linguistics of University of Oklahoma.

-----. 1991. Intelligibility and Test Design. In: Kindell, Gloria E., ed. 1991. Proceedings of the Summer Institute of Linguistics International Language Assessment Conference, Horsleys Green, 23-31 May 1989. Dallas: Summer Institute of Linguistics.

Constitution of Afghanistan. 2005. http://arabic.cnn.com/afghanistan/ConstitutionAfghanistan. Last accessed August 11, 2008.

Dodikhudoeva, Leyla. 2004. The Tajik language and the socio-linguistic situation in the mountainous Badakhshan. Iran \& the Caucasus. Vol. 8, Issue 2. 281-288.

Gordon, Raymond G., Jr. (ed.). 2005. Ethnologue: Languages of the World. Fifteenth edition., Tex. SIL International: Dallas. Online version: http://www.ethnologue.com/. Last accessed November 26, 2006.

Grimes, Barbara F. 1990. Why test intelligibility? In: Bergman, T.G. (Ed.). Language Assessment Criteria. Survey Reference Manual. Dallas: Summer Institute of Linguistics.

Grimes, Joseph E. 1997. Language Survey Reference Guide. Dallas: Summer Institute of Linguistics.

Emadi, Hafizullah. 2005. Nahzat-e-Nawin: modernization of the Badakhshani Isma'ili communities in Badakhshan. Central Asian Survey 24. Routledge.

Karan, Mark and Jürg Stalder. 2000. Assessing motivation: Techniques for researching the motivations behind language choice. In: Assessing ethnolinguistic vitality: Theory and practice, selected papers from the Third International Language Assessment Conference. Eds: Gloria Kindell, M. Paul Lewis. 189-205. Dallas: SIL International.

Kindell, Gloria (ed.). 1991. Proceedings of the Summer Institute of Linguistics International Language Assessment Conference. 1989. Dallas: SIL International.

Lorimer, D.L.R. 1922. The Phonology of the Bakhtiari, Badakhshani, and Madaglashti dialects of Modern Persian, with vocabularies. London: Royal Asiatic Society.

Landweer, Lynn. 2000. Indicators of Ethnolinguistic Vitality. Notes on Sociolinguistics 5.1. Dallas: Summer Institute of Linguistics.

Payne, John. 1989. Pamir Languages. In: Rüdiger Schmitt, R. (ed.). Compendium Linguarum Iranicarum. Wiesbaden: Ludwig Reichert. 417-44.

Schirrmacher, Christine. 1994. Der Islam: Geschichte, Lehre, Unterschiede zum Christentum. Hänssler: Stuttgart.

Skjærvø, Prods O. 1989. Modern East Iranian Languages. In: Rüdiger Schmitt (ed.). Compendium Linguarum Iranicarum. Wiesbaden: Ludwig Reichert. 270-83.

Swadesh, M. 1955. Towards Greater Accuracy in Lexicostatistical Dating. In International Journal of American Linguistics, 21. 
The Great Game. 2008. Wikipedia, the free encyclopaedia. http://en.wikipedia.org/wiki/Great_Game. Last accessed February 18, 2008.

Thiessen, Gabriela et al. 2005. Language Access and Tajik Language Proficiency: Yazghulami. In: Clifton, John M. (ed.). 2005. Studies in Languages of Tajikistan. Dushanbe: National State University of Tajikistan; St. Petersburg: North Eurasia Group, SIL International. Wimbish, John. 1989. WordSurv 6.0.2. Dallas: Taylor University and SIL International.

Author's Contact Information:

Simone Beck

Simbeck07@aol.com 
Appendix A: Word List Results 5

\begin{tabular}{|c|c|c|c|c|c|c|c|c|c|c|c|c|c|c|c|c|c|c|c|}
\hline & \begin{tabular}{|l|} 
Engl. \\
\end{tabular} & Dari & \begin{tabular}{|l} 
Dari $^{6}$ \\
IPA
\end{tabular} & \begin{tabular}{|l|} 
Retow \\
\end{tabular} & Khizaw & \begin{tabular}{|l|} 
Darra-e \\
Sher
\end{tabular} & Warw & \begin{tabular}{|l|} 
Ghu- \\
may
\end{tabular} & \begin{tabular}{|l} 
Jumarj- \\
e Bālā
\end{tabular} & Zanif & $\begin{array}{l}\text { Māyma } \\
\text { y }\end{array}$ & Rezway & \begin{tabular}{|l|} 
Ubagh \\
n
\end{tabular} & Nusay & $\begin{array}{l}\text { Nar- } \\
\text { ghaw }\end{array}$ & \begin{tabular}{|l} 
Zenger- \\
yā
\end{tabular} & Jārf & Laron & $\begin{array}{l}\text { Qala-e } \\
\text { Kuf }\end{array}$ \\
\hline 1. & $\mathrm{I}-1 \mathrm{~s}$ & من & ma & mon & mun & mon & ma & $\mathrm{ma}$ & mon & man & mun & mun & $\mathrm{ma}$ & mun & ma & mun & mon & mun & mun \\
\hline 2. & you-2s & تو & tu & to & to & to & tu & tu & tu & tu & tu & tu & tu & tu & tu & tu & tu & tu & tu \\
\hline 3. & he/she- $3 \mathrm{~s}$ & او & $\mathrm{u}$ & $\mathrm{u}$ & $\mathrm{u}$ & $\mathrm{u}$ & $\mathrm{u}$ & $\mathrm{u}$ & $\mathrm{u}$ & $\mathrm{u}$ & $\mathrm{u}$ & $\mathrm{u}$ & $\mathrm{u}$ & $\mathrm{u}$ & $\mathrm{u}$ & $u$ & $\mathrm{u}$ & $\mathrm{u}$ & $\mathrm{u}$ \\
\hline 4. & we $-1 p$ & ما & $\mathrm{mo}$ & mo & mo & $\mathrm{mo}$ & mo & mo & mo & mo & mo & $\mathrm{mo}$ & mo & mo & mo & mo & mo & mo & mo \\
\hline 5. & you- $2 p$ & شما & Su'ms & Su'mo & Su'mo & Su'mo & Su'mo & Ju'mo & Su'mo & Su'mo & Su'mo & Su'mo & Su'mo & Su'mo & Su'mo & Su'mo & Su'mo & Su'mo & Su'mo \\
\hline 6. & they-3p & آنها & u'no & u'no & u'no & u'no & u'no & u'no & u'no & u'no & u'no & u'no & u'no & u'no & u'no & u'no & u'no & u'no & u'no \\
\hline 7. & who & كى & ki: & ki: & ki: & ki: & ki: & ki: & ki: & ki: & $\mathrm{ki}:$ & $\mathrm{ki}:$ & ki: & ki: & ki: & ki: & ki: & ki: & ki: \\
\hline 8. & what & جىى & $\mathrm{t} f \mathrm{ii}$ & t5i: & tfi: & tfi: & t $\int \mathrm{i}:$ & t5i: & tfii & t $5 \mathrm{i}$ & tfi: & t $\mathrm{i} i$ & t $\int \mathrm{i}:$ & t5i: & $\mathrm{t}$ fi: & t $5 \mathrm{i}$ & tfi: & t5i: & t fi: \\
\hline 9. & where & كجا & ku'd3o & ko & ko & ko & ku'dzo & ku'dzo & ku'dzo & ko & ko & ko & ku'dzo & ko & ku'd3o & ko & ko & ko & ko \\
\hline 10. & when & جى وقت & \begin{tabular}{|l|}
$\mathrm{t} f \mathrm{i}$ \\
waxt \\
\end{tabular} & $\mathrm{t} \int \mathrm{i}$ waxt & tfi waxt & tsi waxt & tfi waxt & $\mathrm{t} \int \mathrm{i}$ waxt & kaj waxt & tfi waxt & kaj waxt & t $\mathrm{i}$ waxt & t $\mathrm{fi}$ waxt & tfi waxt & tfi waxt & kaj waxt & tfi waxt & tfi waxt & kaj \\
\hline 11. & $\begin{array}{l}\text { how } \\
\text { many }\end{array}$ & جند & tfant & t tant & tfant & t fant & t fant & tfant & tfant & t fant & t fant & t fant & t tant & tfant & tfant & tfant & \begin{tabular}{|l}
$\mathrm{t} f \mathrm{i}$ \\
qa'dar
\end{tabular} & 'tfrqa & t fant \\
\hline 12. & this & اين & i: & i:n & i: & nain & i: & i: & i: & i: & i: & i: & i: & i: & is & i: & i: & i: & i: \\
\hline 13. & that & آن & u: & u: & u: & jow & u: & u: & u: & u: & u: & u: & u: & u: & u: & U: & U: & on & u: \\
\hline 14. & these & اينها & i'no & i'no & i'no & nain & i'no & i'no & i'no & i'no & i'no & i'no & i'no & i'no & i'no & 'ino & i'no & i'no & i'no \\
\hline 15. & those & آنها & u'no & u'no & u'no & najow & u'no & u'no & u'no & u'no & u'no & u'no & u'no & u'no & u'no & U: & u'no & u'no & u'no \\
\hline 16. & far & دور & du:r & dy:r & dy:r & du:r & du:r & dy:c & dy:r & dy:r & dy:r & dy:r & du:r & dy:r & dy:r & dy:r & dy:r & dy:r & du:r \\
\hline 17. & near & نزديك & naz'di:k & qa'ribb & naz'di:k & naz'di:k & naz'di:k & \begin{tabular}{|l|} 
naz'di:k \\
\end{tabular} & qa'rip & naz'di:k & qa'rip & qa'rip & naz'di:k & naz'di:k & naz'di:k & qa'rip & qa'rip & qa'rip & naz'di:k \\
\hline 18. & $\begin{array}{l}\text { down/ } \\
\text { below }\end{array}$ & بֶائن & po'jin & baj'tak & baj'tak & baj'tak & baj'tak & baj'tak & baj'tak & baj'tak & kala'po & kala'po & po'jin & kala'po & kala'po & nə'Sep & sarnə'Jep & ne'Sep & po'jin \\
\hline 19. & \begin{tabular}{|l|} 
up/ \\
above
\end{tabular} & بالا & bo'lo & baj'tors & baj'tors & baj'to: & baj'to: & baj'tor: & baj'to: & baj'tor & labo'lo & rubs'ls & bo'lo & lobo'lo & lobs'lo & rubs'lo & sarbo'lo & sarbo'lo & sarbo'lo \\
\hline \multirow[t]{2}{*}{20.} & \begin{tabular}{|l} 
come \\
$N P$ \\
\end{tabular} & ميآيه & 'mjoja & 'mjoja & 'byuma & \begin{tabular}{|l|} 
'byuma \\
\end{tabular} & 'mjoja & 'mjoja & 'mjoja & 'mjoja & \begin{tabular}{|l|} 
'mesja \\
\end{tabular} & 'meoja & \begin{tabular}{|l|} 
'meoja \\
\end{tabular} & 'meoja & 'meoja & \begin{tabular}{|l|} 
'uma \\
\end{tabular} & 'uma & 'oma & 'mjoja \\
\hline & come $P$ & آمد & 'omat & 'omat & 'uma & 'uma & 'omat & 'omat & 'uma & 'omat & 'umat & 'omat & 'omat & 'byuma & 'byuma & 'byuma & 'byuma & 'byuma & 'omat \\
\hline 21. & sit $N P$ & ميشند & 'mISIna & 'mıSIna & 'mIJina & 'mrJina & 'misina & 'mIJina & 'mrJina & 'misına & 'misina & 'misina & 'misina & 'mIJina & 'mISIna & 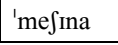 & 'mesina & 'mesina & 'mesina \\
\hline
\end{tabular}

${ }^{5}$ The stops $[\mathrm{p}],[\mathrm{t}]$ and $[\mathrm{k}]$ are always aspirated when a vowel follows, the aspiration is not transcribed.

When words end with a voiced consonant the final sound is usually devoiced. This is transcribed in the 'Dari IPA' column, while in the Dari script a voiced consonant appears.

${ }^{6}$ Dari variety as spoken in Faizabad 


\begin{tabular}{|c|c|c|c|c|c|c|c|c|c|c|c|c|c|c|c|c|c|c|c|}
\hline & sit $P$ & نشست & SI $\int \mathrm{t}$ & Jist & Sist & SISt & $\int \mathrm{I} \int \mathrm{t}$ & Jist & Sist & Jist & SIst & SIft & $\int \mathrm{I} \int \mathrm{t}$ & \begin{tabular}{|l|} 
'bofist \\
\end{tabular} & SIft & 'bofist & Sist & 'bofist & Sist \\
\hline \multirow{2}{*}{22.} & stand $N P$ & | ميشود & $\begin{array}{l}\text { ost'od } \\
\text { 'me } \int \mathrm{a}\end{array}$ & \begin{tabular}{|l} 
wud3 \\
Sist ast
\end{tabular} & $\begin{array}{l}\text { wod3 } \\
\text { fist ast }\end{array}$ & wud3 ast & $\begin{array}{l}\text { ost'od } \\
\text { 'me } a\end{array}$ & $t \int \mathrm{Ixt}$ & 'mexeza & $\begin{array}{l}\text { ast'od } \\
\text { 'me } a\end{array}$ & $\begin{array}{l}\text { əst'’d } \\
\text { 'me } a\end{array}$ & $\begin{array}{l}\text { ost'od } \\
\text { 'me } a\end{array}$ & $\begin{array}{l}\text { ost'od } \\
\text { 'mesa }\end{array}$ & $\begin{array}{l}\text { əst'’d } \\
\text { 'mesa }\end{array}$ & $\begin{array}{l}\text { ost'od } \\
\text { 'me } a\end{array}$ & $\begin{array}{l}\text { t } \int y x t \\
\text { 'mekuna }\end{array}$ & 'mexeza & $\begin{array}{l}\text { qa'ror } \\
\text { 'mekuna }\end{array}$ & $\begin{array}{l}\text { ost'od } \\
\text { 'mesa }\end{array}$ \\
\hline & stand $P$ & استاد شد & \begin{tabular}{|l} 
ost'ot \\
Jut
\end{tabular} & $\begin{array}{l}\text { wud3 } \\
\text { fi: }\end{array}$ & wod3 fi: & wud3 ast & əst'ot Sut & t $\int \mathrm{IX} \int \mathrm{I} \int \mathrm{t}$ & xest & әst'ot Si: & tfixt kat & $\begin{array}{l}\text { ost'ot } \\
\text { fud }\end{array}$ & $\begin{array}{l}\text { ost'ot } \\
\text { Sut }\end{array}$ & \begin{tabular}{|l|} 
t Ixt kat \\
\end{tabular} & \begin{tabular}{|l} 
ost'Jt \\
Sut
\end{tabular} & t $\int Y x t$ kat & \begin{tabular}{|l|}
$\mathrm{t} \int \mathrm{YXt}$ \\
kat
\end{tabular} & $\begin{array}{l}\text { qa'ror } \\
\text { kat }\end{array}$ & əst'ot $\int \mathrm{I}$ \\
\hline \multirow{2}{*}{23.} & $\begin{array}{l}\text { lie down } \\
N P\end{array}$ & ميكثد & $\begin{array}{l}\text { dar'oz } \\
\text { 'mekafa }\end{array}$ & \begin{tabular}{|l} 
dar'oz \\
'mekafa
\end{tabular} & $\begin{array}{l}\text { dar'oz } \\
\text { 'mekuna }\end{array}$ & $\begin{array}{l}\text { dar'sz } \\
\text { 'mekaja }\end{array}$ & $\begin{array}{l}\text { dar'sz } \\
\text { 'mekaja }\end{array}$ & $\begin{array}{l}\text { dar'oz } \\
\text { 'mekafa }\end{array}$ & \begin{tabular}{|l} 
for'oz \\
'mekafa
\end{tabular} & $\begin{array}{l}\text { dar'sz } \\
\text { 'mekafa }\end{array}$ & \begin{tabular}{|l} 
dar'oz \\
'mekafa
\end{tabular} & \begin{tabular}{|l|l} 
dar'oz \\
'mekafa \\
\end{tabular} & $\begin{array}{l}\text { dar'sz } \\
\text { 'mekafa }\end{array}$ & \begin{tabular}{|l|} 
dar'oz \\
'mekafa
\end{tabular} & \begin{tabular}{|l|} 
dar'oz \\
'mekafa
\end{tabular} & 'boyeli & 'meyela & $\begin{array}{l}\text { dar'oz } \\
\text { 'mekafa }\end{array}$ & $\begin{array}{l}\text { dar'sz } \\
\text { 'mekafa }\end{array}$ \\
\hline & $\begin{array}{l}\text { lie down } \\
P\end{array}$ & كثشيد & $\begin{array}{l}\text { dar'ss } \\
\text { ka'jit }\end{array}$ & $\begin{array}{l}\text { dar'ss } \\
\text { ka'jit }\end{array}$ & $\begin{array}{l}\text { dar'os } \\
\text { ka'jit }\end{array}$ & $\begin{array}{l}\text { dar'os } \\
\text { ka'Jit }\end{array}$ & $\begin{array}{l}\text { dar'os } \\
\text { ka'fit }\end{array}$ & $\begin{array}{l}\text { dar'os } \\
\text { ka'fit }\end{array}$ & $\begin{array}{l}\text { dar'os } \\
\text { ka'fit }\end{array}$ & $\begin{array}{l}\text { dar'ss } \\
\text { ka'fit }\end{array}$ & $\begin{array}{l}\text { dar'os } \\
\text { ka'fit }\end{array}$ & $\begin{array}{l}\text { dar'os } \\
\text { ka'fit }\end{array}$ & $\begin{array}{l}\text { dar'os } \\
\text { ka'fit }\end{array}$ & 'ye:li & $\begin{array}{l}\text { dar'os } \\
\text { ka'fit }\end{array}$ & 'bəyeli & $\begin{array}{l}\text { dar'os } \\
\text { ka'fit }\end{array}$ & $\begin{array}{l}\text { dar'os } \\
\text { ka'jit }\end{array}$ & $\begin{array}{l}\text { dar'os } \\
\text { ka'Sit }\end{array}$ \\
\hline \multirow{2}{*}{24.} & give $N P$ & ميدهد & 'meta & 'meta & 'meta & 'meta & 'meta & 'meta & 'meda & 'meda & 'meda & 'meta & 'meta & 'meda & 'meta & 'meta & 'meda & 'meta & 'meta \\
\hline & give $P$ & |داد & dot & dot & $\mathrm{dot}$ & dot & dot & dot & do & dot & dot & dod & $d s t$ & $d s t$ & dot & do & do & dot & dot \\
\hline \multirow[t]{2}{*}{25.} & walk $N P$ & قدمند & 'mera & merawa & 'merawa & 'merawa & 'merawa & 'mera & 'merawa & 'merawa & 'merawa & 'merawa & 'mera & 'merawa & 'rawame & 'merawa & 'merawa & 'merawa & 'merawa \\
\hline & walk $P$ & قدمزد & raft & raft & raft & raft & raft & raft & raft & raft & raft & raft & raft & raft & raft & 'bəraft & raft & 'boraft & raft \\
\hline \multirow{2}{*}{26.} & $\begin{array}{l}\text { fly (bird) } \\
N P\end{array}$ & |ميبيرد & 'mepara & 'mepara & 'mepara & 'mepara & 'mepara & 'mepara & 'mepara & 'mepara & 'mepara & 'mepara & 'mepara & 'mepara & 'mepara & $\begin{array}{l}\text { par'woz } \\
\text { 'mekuna }\end{array}$ & $\begin{array}{l}\text { par'woz } \\
\text { mekuna }\end{array}$ & $\begin{array}{l}\text { par'wos } \\
\text { 'mekuna }\end{array}$ & 'mepara \\
\hline & $\begin{array}{l}\text { fly (bird) } \\
P\end{array}$ & | يريد & pa'rit & pa'rit & pa'rit & pa'rit & pa'rit & pa'rit & pa'rit & pa'rit & pa'rit & pa'rit & pa'rit & $\begin{array}{l}\text { par'wos } \\
\text { Si: }\end{array}$ & pa'rit & 'bəparit & pa'rit & $\begin{array}{l}\text { par'wos } \\
\text { ji: }\end{array}$ & pa'rit \\
\hline \multirow{2}{*}{27.} & wash $N P$ & ميشيود & 'meðəja & 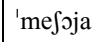 & 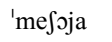 & 'me`əja & 'me`əja & 'meऽəja & 'meðəja & 'me`əja & 'meðoja & 'meðəja & 'me`oja & 'meðəja & 'meðoja & 'me`əja & 'meðəja & 'me`əja & 'meكəja \\
\hline & wash $P$ & شست & Suft & Just & Sust & Sust & Sust & fust & Sust & Suft & Sust & suft & SuSt & 'bəfISt & fust & 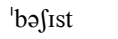 & SIst & SIJt & Jist \\
\hline \multirow{2}{*}{28.} & split $N P$ & ميكند & $\begin{array}{l}\text { maj'da } \\
\text { 'mekuna }\end{array}$ & $\begin{array}{l}\text { re'za } \\
\text { mekuna }\end{array}$ & $\begin{array}{l}\text { re'za } \\
\text { 'mekuna }\end{array}$ & $\begin{array}{l}\text { XYr } \\
\text { 'mekuna }\end{array}$ & $\begin{array}{l}\text { maj'da } \\
\text { 'mekuna }\end{array}$ & $\begin{array}{l}\text { XYr } \\
\text { mekuna }\end{array}$ & \begin{tabular}{|l|l|} 
XYr \\
'mekuna \\
\end{tabular} & $\begin{array}{l}\text { XYr } \\
\text { 'mekuna }\end{array}$ & \begin{tabular}{|l|} 
XYr \\
'mekuna \\
\end{tabular} & \begin{tabular}{|l} 
XYr \\
'mekuna
\end{tabular} & $\begin{array}{l}\text { maj'da } \\
\text { mekuna }\end{array}$ & $\begin{array}{l}\text { re'za } \\
\text { mekuna }\end{array}$ & $\begin{array}{l}\text { maj'da } \\
\text { mekuna }\end{array}$ & $\begin{array}{l}\text { XYr } \\
\text { 'mekuna }\end{array}$ & \begin{tabular}{|l|l} 
Xyr \\
mekuna
\end{tabular} & $\begin{array}{l}\text { maj'da } \\
\text { 'mekuna }\end{array}$ & $\begin{array}{l}\text { Xyr } \\
\text { mekuna }\end{array}$ \\
\hline & split $P$ & ميده كرد & \begin{tabular}{|l|} 
maj'da \\
kat
\end{tabular} & \begin{tabular}{|l} 
re'za \\
kat
\end{tabular} & re'za kat & XYr kat & \begin{tabular}{|l} 
maj'da \\
kat \\
\end{tabular} & XYr kat & XYr kat & XYr kat & XYr kat & XYr kat & \begin{tabular}{|l} 
maj'da \\
kat \\
\end{tabular} & \begin{tabular}{|l} 
re'za \\
kat \\
\end{tabular} & \begin{tabular}{|l} 
maj'da \\
kat
\end{tabular} & XYr kat & XYr kat & $\begin{array}{l}\text { maj'da } \\
\text { kat }\end{array}$ & XYr kat \\
\hline \multirow{2}{*}{29.} & $\operatorname{dig} N P$ & ميز بيل & \begin{tabular}{|l|} 
bel \\
'mezana
\end{tabular} & $\begin{array}{l}\text { po'bel } \\
\text { mekuna }\end{array}$ & $\begin{array}{l}\text { po'bel } \\
\text { 'mekuna }\end{array}$ & $\begin{array}{l}\text { po'bel } \\
\text { 'mekuna }\end{array}$ & \begin{tabular}{|l} 
bel \\
'mezana \\
\end{tabular} & \begin{tabular}{|l|} 
bel \\
'mezana \\
\end{tabular} & \begin{tabular}{|l|} 
bel \\
'mezana \\
\end{tabular} & $\begin{array}{l}\text { bel } \\
\text { 'mezana }\end{array}$ & \begin{tabular}{|l} 
bel \\
'mezana \\
\end{tabular} & $\begin{array}{l}\text { bel } \\
\text { 'mezana } \\
\end{array}$ & $\begin{array}{l}\text { bel } \\
\text { Imezana }\end{array}$ & \begin{tabular}{|l|} 
bel \\
'zaname \\
\end{tabular} & \begin{tabular}{|l|} 
bel \\
'mezana \\
\end{tabular} & $\begin{array}{l}\text { po'bel } \\
\text { 'mekuna }\end{array}$ & $\begin{array}{l}\text { po'bəl } \\
\text { mekuna }\end{array}$ & $\begin{array}{l}\text { po'bəl } \\
\text { 'mekuna }\end{array}$ & \begin{tabular}{|l} 
bel \\
'mezana
\end{tabular} \\
\hline & $\operatorname{dig} P$ & بيل زد & bel zat & \begin{tabular}{|l} 
po'bel \\
kat
\end{tabular} & $\begin{array}{l}\text { po'bel } \\
\text { kat }\end{array}$ & $\begin{array}{l}\text { po'bel } \\
\text { kat }\end{array}$ & bel zat & bel zat & bel zat & bel zat & bel zat & bel zat & bel zat & bel zo & bel zat & $\begin{array}{l}\text { po'bel } \\
\text { kat }\end{array}$ & \begin{tabular}{|l} 
po'bal \\
kat
\end{tabular} & $\begin{array}{l}\text { po'bal } \\
\text { zat }\end{array}$ & bel zat \\
\hline \multirow{2}{*}{30.} & \begin{tabular}{|l|} 
squeeze \\
$N P$ \\
\end{tabular} & ميُجوند & \begin{tabular}{|l|} 
pu'tfuq \\
'mekuna
\end{tabular} & $\begin{array}{l}\text { b'yat } \\
\text { mekuna }\end{array}$ & $\begin{array}{l}\text { 'me- } \\
\text { yaw3a }\end{array}$ & $\begin{array}{l}\text { lo'yat } \\
\text { 'mekuna }\end{array}$ & $\begin{array}{l}\text { pu'tfuq } \\
\text { 'mekuna }\end{array}$ & $\begin{array}{l}\text { pu'tfuq } \\
\text { 'mekuna }\end{array}$ & \begin{tabular}{|l} 
lo'yat \\
'mekuna
\end{tabular} & $\begin{array}{l}\text { lo'yat } \\
\text { 'mekuna }\end{array}$ & $\begin{array}{l}\text { lo'yat } \\
\text { 'mekuna }\end{array}$ & $\begin{array}{l}\text { pu'tfuq } \\
\text { 'mekuna }\end{array}$ & $\begin{array}{l}\text { pu'tfuq } \\
\text { mekuna }\end{array}$ & $\begin{array}{l}\text { lo'yat } \\
\text { Imekuna }\end{array}$ & $\begin{array}{l}\text { lo'yat } \\
\text { mekuna }\end{array}$ & $\begin{array}{l}\text { lo'yat } \\
\text { 'mekuna }\end{array}$ & $\begin{array}{l}\text { lo'yat } \\
\text { mekuna }\end{array}$ & $\begin{array}{l}\text { lo'yat } \\
\text { 'mekuna }\end{array}$ & $\begin{array}{l}\text { lo'yat } \\
\text { mekuna }\end{array}$ \\
\hline & $\begin{array}{l}\text { squeeze } \\
P\end{array}$ & גירט كرد & $\begin{array}{l}\text { pu'tfuq } \\
\text { kat }\end{array}$ & $\begin{array}{l}\text { lo'yat } \\
\text { kat }\end{array}$ & $\begin{array}{l}\text { 'bo- } \\
\text { yawzid }\end{array}$ & pyt $\int \mathrm{i}:$ & $\begin{array}{l}\text { pu'tfuq } \\
\text { kat }\end{array}$ & $\begin{array}{l}\text { pu'tfuq } \\
\text { kat }\end{array}$ & lo'yat kat & lo'yat kat & $\begin{array}{l}\text { lo'yat } \\
\text { kat }\end{array}$ & $\begin{array}{l}\text { pu'tfuq } \\
\text { kat }\end{array}$ & $\begin{array}{l}\text { pu'tfuq } \\
\text { kat }\end{array}$ & $\begin{array}{l}\text { lo'yat } \\
\text { kat }\end{array}$ & $\begin{array}{l}\text { lo'yat } \\
\text { kat }\end{array}$ & lo'yat kat & $\begin{array}{l}\text { lo'yat } \\
\text { kat }\end{array}$ & $\begin{array}{l}\text { lo'yat } \\
\text { kat }\end{array}$ & $\begin{array}{l}\text { lo'yat } \\
\text { kat }\end{array}$ \\
\hline 31. & night & شب شب & Jaw & Saw & Saw & Saw & Sap & Saw & Sap & Sap & Sap & Sap & Saw & Saw & Saw & Saw & Saw & Sap & Sap \\
\hline 32. & day & روز & ru:s & russ & rø:s & ruis & ruis & ru:s & russ & ruis & ruis & ruis & ruis & ruis & ru:s & rY:S & ru:s & ru:s & ruis \\
\hline 33. & one & يك & jak & jak & jak & jak & jak & jak & jak & jak & jak & jak & jak & jak & jak & jak & jak & jak & jak \\
\hline 34. & two & | دو & du: & du: & du: & du: & du: & du: & du: & du: & du: & du: & du: & du: & du: & du: & du: & du: & du: \\
\hline 35. & three & سه سه & se: & se: & se: & se: & se: & se: & se: & se: & se: & se: & se: & se: & se: & se: & se: & se: & se: \\
\hline 36. & four & جهار & t 5 o: & t5o: & 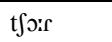 & t to: & tfo:s & t5o:s & tfo: & t to: & tfo:r & tfors & t5o:r & t $\int a: r$ & t fors & t for & t5o: & tfors & t $\int$ or \\
\hline
\end{tabular}




\begin{tabular}{|c|c|c|c|c|c|c|c|c|c|c|c|c|c|c|c|c|c|c|c|}
\hline 37. & five & ينج & pand3 & pand 3 & pand3 & pand 3 & pand3 & pand 3 & pand3 & pand3 & pand3 & pand3 & pand3 & pand 3 & pand3 & pand3 & pand 3 & pand3 & pand3 \\
\hline 38. & six & شش & $\mathrm{saf}$ & SaS & $\mathrm{SaS}$ & Sas & $\mathrm{saf}$ & Sas & $\mathrm{SaS}$ & Sas & fas & SaS & Sas & $\int \mathrm{a} \int$ & SaS & $\mathrm{SaS}$ & Sas & Sas & $\mathrm{sas}$ \\
\hline 39. & seven & هفت & aft & aft & aft & aft & aft & aft & aft & aft & aft & aft & aft & aft & aft & aft & aft & aft & aft \\
\hline 40. & eight & هشت & aft & aft & aft & aft & aft & aft & aft & aft & aft & aft & aft & aft & aft & aft & aft & aft & aft \\
\hline 41. & nine & نو & no: & no: & no: & no: & no: & no: & no: & no: & no: & no: & no: & no: & no: & no: & no: & no: & no: \\
\hline 42. & ten & ده & da & da & da & da & da & da & da & da & da & da & da & da & da & da & da & da & da \\
\hline 43. & eleven & يازده & joz'da & joz'da & joz'da & joz'da & joz'da & joz'da & joz'da & joz'da & joz'da & joz'da & joz'da & joz'da & joz'da & joz'da & joz'da & joz'da & jəz'da \\
\hline 44. & twelve & دو ازده & dwoz'da & dwoz'da & dwoz'da & dwoz'da & dwoz'da & dwoz'da & dwoz'da & dwoz'da & dwoz'da & dwoz'da & dwoz'da & dwoz'da & dwoz'da & dwoz'da & dwoz'da & dwoz'da & dwoz'da \\
\hline 45. & twenty & بيست & bist & bist & bist & bist & bist & bist & bist & bist & bist & bist & bist & bist & bist & bist & bist & bist & bist \\
\hline 46. & hundred & صد & sat & sat & sat & sat & sat & sat & sat & sat & sat & sat & sat & sat & sat & sat & sat & sat & sat \\
\hline 47. & all & تمام & ta'mom & 'ama & 'ama & 'ama & ta'mom & 'ama & 'ama & 'ama & 'ama & 'ama & ta'mom & 'ama & 'ama & 'ama & 'ama & 'ama & 'ama \\
\hline 48. & many & زياد & zjot & pur & pur & zjot & pur & pur & pur & pur & pur & pur & zjot & pur & pur & pur & pur & pur & pur \\
\hline 49. & few & كمى & kam & kam & kam & kam & kam & kam & an'dak & kam & kam & kam & kam & kam & kam & kam & an'dak & an'dak & kam \\
\hline 50. & big & كلان & ka'lon & ka'ta & ka'ta & ka'ta & ka'ta & ka'ta & ka'ta & ka'ta & ka'ta & ka'ta & ka'lon & ka'ta & ka'ta & ka'ta & ka'ta & ka'ta & ka'ta \\
\hline 51. & small & خورد & xurt & maj'da & maj'da & maj'da & maj'da & maj'da & rez'gak & maj'da & maj'dak & maj'da & xurt & \begin{tabular}{|l} 
majtə- \\
'kjak
\end{tabular} & maj'da & maj'dak & \begin{tabular}{|l} 
majdI- \\
'kak
\end{tabular} & \begin{tabular}{|l} 
majda- \\
'kak
\end{tabular} & maj'da \\
\hline 52. & \begin{tabular}{|l} 
long \\
\end{tabular} & دراز & da'ros & do'ro:s & do'coss & do'ro:s & da'ros & da'ros & da'ros & da'ros & da'ros & da'ros & da'ros & da'ros & da'sos & da'ros & da'ros & da'ros & da'ros \\
\hline 53. & short & كوتاه & ko'to & ko'ta & kø'ta & kø'ta & ko'to & ko'to & køt'kak & pas'tak & køtə'kak & ko'ta & ko'to & køtə'kjak & kø'to & køt'kak & kø'ta & ko'ta & ko'ta \\
\hline 54. & sun & آفتاب & af'taw & \begin{tabular}{|l|} 
af'taw \\
\end{tabular} & ef'tow & af'tow & af'taw & af'taw & af'taw & af'taw & af'tow & af'taw & af'taw & af'taw & af'taw & af'taw & af taw & af'taw & af'taw \\
\hline 55. & moon & مهتاب & ma'taw & ma'taw & ma'taw & ma'taw & ma'taw & ma'taw & ma'taw & ma'taw & ma'taw & ma'taw & ma'taw & ma'taw & ma'taw & ma'taw & ma'taw & ma'taw & ma'taw \\
\hline 56. & star & ستاره & səto'ra & səto'ra & sato'ra & səto'ra & səto'ra & səto'ra & səto'ra & səto'ra & sato'ra & səto'ra & səto'ra & səto'ra & səto'ra & sato'ra & səto'ra & səto'ra & səto'ra \\
\hline 57. & water & آب & ow & ow & ○W & ow & ow & ow & ○W & ow & ow & ow & ow & ow & ow & ow & ow & aw & ow \\
\hline 58. & rain & بار ان & bo'ron & bo'ron & bo'run & bo'ron & bo'ron & bo'ron & bo'rys & bo'run & bo'run & bo'rys & bo'ron & bo'rys & bo'rys & bo'rys & bo'ru: & bo'rys & bo'rys \\
\hline 59. & stone & سنگ & sank & sayk & sayk & sayk & sank & sank & sank & sayk & sank & sayk & sayk & sayk & sayk & sayk & sank & sank & sank \\
\hline 60. & sand & ريخ & re:k & re:k & re:k & re:k & re:k & re:k & re:k & re:k & re:k & re:k & re:k & re:k & re:k & re:k & re:k & re:k & re:k \\
\hline 61. & earth & زمين & zo'min & zo'mi:n & zo'mi:n & zo'mi:n & zo'mi:n & zo'min & zo'min & zo'mi:n & zo'mi:n & zo'mi:n & zo'mi:n & zo'mi:n & za'mi:n & zo'min & zo'mi:n & zo'mi:n & zo'min \\
\hline 62. & cloud & |بر & abr & abr & awr & abs & abr & $a b r$ & awr & awr & \begin{tabular}{|l|} 
awr \\
\end{tabular} & awr & abr & awr & abs & awr & hawr & haws & \begin{tabular}{|l|} 
awr \\
\end{tabular} \\
\hline 63. & smoke & دود & dut & $d y x$ & dyx & $\mathrm{dyt}$ & dut & dut & dyx & $d y x$ & dux & dyx & dut & $\mathrm{dyt}$ & dut & dyx & dyx & $\mathrm{dyt}$ & dut \\
\hline 64. & fire & آتش & o'tes & a'low & a'low & o'tas & o'tas & a'low & a'low & a'low & a'low & a'low & o'tes & a'low & a'low & a'low & a'low & a'low & a'low \\
\hline 65. & ash & |خاكستر & xokəs'tar & xokəs'tar & xəkəs'tar & xokəs'tar & xokəs'tar & xokəs'tar & xokəs'tar & xokəs'tar & xokəs'tar & xokəs'tar & xokəs'tar & xokəs'tar & xokəs'tar & xəkəs'tar & xokəs'tar & xokəs'tar & xokəs'tar \\
\hline 66. & \begin{tabular}{|l|} 
moun- \\
tain
\end{tabular} & كوه & ko: & ko: & ko: & ko: & ko: & ko: & ko: & ko: & ko: & ko: & ko: & ko: & ko: & ko: & ko: & ko: & ko: \\
\hline 67. & tree & درخت & do'raxt & də'raxt & \begin{tabular}{|l|} 
do'raxt \\
\end{tabular} & do'raxt & do'raxt & da'raxt & \begin{tabular}{|l} 
da'raxt \\
\end{tabular} & də'raxt & do'raxt & do'raxt & də'raxt & do'raxt & da'raxt & də'raxt & do'raxt & do'raxt & do'raxt \\
\hline 68. & seed & تخم & 'tuxəm & 'tuxəm & 'tuxəm & 'tuxəm & 'tuxəm & 'tuxəm & 'tuxəm & 'tuxəm & 'tuxəm & 'tuxəm & 'tuxəm & 'tuxəm & \begin{tabular}{|l|} 
'tuxəm \\
\end{tabular} & 'tuxəm & 'tuxom & \begin{tabular}{|l} 
'tuxəm \\
\end{tabular} & \begin{tabular}{|l} 
'tuxom \\
\end{tabular} \\
\hline 69. & leaf & برى & bark & bark & bark & bark & bark & bark & bark & bark & bark & bark & bark & bark & bark & bark & bark & bark & bark \\
\hline 70. & root & ريشـه & ri'fa & rI'fa & rI'fa & ri'fa & ri'ja & rI'Sa & rI'fa & ri' ${ }^{\prime} \mathrm{a}$ & ri'ja & rI'fa & ri'fa & ri'ja & \begin{tabular}{|l|} 
ri' $\int a$ \\
\end{tabular} & rı' & rI' $\int \mathrm{a}$ & ri' ${ }^{\prime} \mathrm{a}$ & ri'fa \\
\hline 71. & bark & درخت & $\begin{array}{l}\text { 'pustə } \\
\text { da'raxt }\end{array}$ & $\begin{array}{l}\text { 'pustə } \\
\text { də'raxt }\end{array}$ & \begin{tabular}{|l|} 
'pustə \\
də'raxt
\end{tabular} & $\begin{array}{l}\text { 'pustə } \\
\text { də'raxt }\end{array}$ & $\begin{array}{l}\text { 'pustə } \\
\text { də'raxt }\end{array}$ & $\begin{array}{l}\text { 'pustə } \\
\text { da'raxt }\end{array}$ & \begin{tabular}{|l|} 
'pystə \\
də'raxt
\end{tabular} & $\begin{array}{l}\text { 'pustə } \\
\text { də'raxt }\end{array}$ & $\begin{array}{l}\text { 'po:stə } \\
\text { də'raxt }\end{array}$ & $\begin{array}{l}\text { 'pustə } \\
\text { də'raxt }\end{array}$ & \begin{tabular}{|l|} 
'pustə \\
də'raxt
\end{tabular} & $\begin{array}{l}\text { 'pystə } \\
\text { də'raxt }\end{array}$ & $\begin{array}{l}\text { 'pustə } \\
\text { də'raxt }\end{array}$ & $\begin{array}{l}\text { 'pøstə } \\
\text { də'raxt }\end{array}$ & $\begin{array}{l}\text { 'pustə } \\
\text { də'raxt }\end{array}$ & $\begin{array}{l}\text { 'pustə } \\
\text { də'raxt }\end{array}$ & $\begin{array}{l}\text { 'pustə } \\
\text { də'raxt }\end{array}$ \\
\hline
\end{tabular}




\begin{tabular}{|c|c|c|c|c|c|c|c|c|c|c|c|c|c|c|c|c|c|c|c|}
\hline 72. & fish & ماهى & mo'i: & mo'ii & mo'i: & mo'i: & mo'i: & mo'i: & mo'i: & mo'i: & mo'ii & mo'ii & mo'i: & mo'i: & mo'i: & mo'i: & mo'i: & mo'i: & mo'i: \\
\hline 73. & bird & |برنده & paron'da & paron'da & parən'da & parən'da & parən'da & parən'da & parən'da & parən'da & parən'da & parən'da & parən'da & parən'da & parən'da & parən'da & \begin{tabular}{|l|} 
parwo- \\
'ZYk
\end{tabular} & paron'da & parən'da \\
\hline 74. & $\operatorname{dog}$ & سگ & sa:k & sa:k & sa:k & sa:k & sa:k & sa:k & sa:k & sa:k & sa:k & sa:k & sa:k & sa:k & sa:k & sa:k & sa:k & sa:k & sa:k \\
\hline 75. & goat & بز & bus & bus & bus & bus & bus & bus & bus & bus & bus & bus & bus & bus & bus & bus & bus & bus & bus \\
\hline 76. & sheep & كو سفند & gos'fant & me: $\int$ & me: $\int$ & me: $\int$ & gos'fant & me: $\int$ & me: $\int$ & me: $\int$ & me:S & me:S & gos'fant & me: $\int$ & gos'fant & me:S & me: $\int$ & gos'fant & me: $\int$ \\
\hline 77. & chicken & مرغ & murx & murx & murx & murx & murx & murx & murx & murx & murx & murx & murx & murx & murx & murx & mo:'ki & murx & murx \\
\hline 78. & cow & كاو & gaw & gəw & gow & gow & gow & gaw & gow & gow & gow & gow & gaw & gəw & gaw & gow & gəw & gaw & gow \\
\hline 79. & ant & مورجه & mur'tfa & mur'tfyk & mur'tfyk & $\begin{array}{l}\text { murtfa- } \\
\text { 'xa }\end{array}$ & mur'tfyk & mur'tfyk & mur'tfyk & mur'tfyk & mur't ${ }^{\prime} y k$ & mur't $\int \mathrm{yk}$ & mur'tfa & mur'tfyk & mur'tfyk & mur'tfyk & mur'tfyk & mur'tfyk & mur'tfyk \\
\hline 80. & woman & زن & zan & zan & zan & zan & zan & zan & za'nak & za'nak & za'nak & za'nak & zan & za'nak & za'nak & za'nak & za'nak & za'nak & za'nak \\
\hline 81. & $\operatorname{man}$ & | مرد & mart & ma'rak & mardi'na & mart & mart & mart & ma'rak & ma'rak & mart & ma'rak & mart & ma'rak & ma'rak & ma'rak & ma'rak & ma'rak & ma'rak \\
\hline 82. & person & نفر & na'far & na'far & na'far & na'far & na'far & na'far & na'far & na'far & na'far & na'far & na'far & na'far & na'far & na'far & na'far & na'far & na'far \\
\hline 83. & skin & يوست & pust & pust & pust & pust & pust & pust & pust & pust & pust & Pust & pust & pyst & pust & pust & pust & pust & pust \\
\hline 84. & $\begin{array}{l}\text { flesh/ } \\
\text { meat }\end{array}$ & كوشت & go: $: t$ & go: $\int t$ & go:St & go:St & go: $\mathrm{ft}_{\mathrm{t}}$ & go: $\int t$ & go:St & go:St & go: $\int t$ & go:ft & go: $\int t$ & gø:St & go:St & gø:ft & go: $\int t$ & go:St & go:ft \\
\hline 85. & bone & استخوان & ustu'xon & Ysta'yon & ax'sun & Yste'yən & asto'yun & astə'yun & asta'yun & Ysta'yən & asto'yun & asto'yun & ustu'xon & aste'yun & astə'yun & asta'yu: & astə'yu: & asta'yun & sta'yun \\
\hline 86. & $\begin{array}{l}\text { grease/ } \\
\text { fat }\end{array}$ & | دنبه & dum'ba & dum'ba & dum'ba & dum'ba & dum'ba & dum'ba & dum'ba & dum'ba & dum'ba & dum'ba & dum'ba & dum'ba & dum'ba & dum'ba & dum'ba & dum'ba & dum'ba \\
\hline 87. & egg & |تخم & 'tuxəm & 'tuxəm & 'tuxəm & 'tuxəm & 'tuxəm & 'tuxəm & 'tuxəm & 'tuxəm & 'tuxəm & 'tuxəm & 'tuxəm & 'tuxəm & 'tuxəm & 'tuxəm & 'tuxəm & 'tuxəm & 'tuxəm \\
\hline 88. & horn & | شاخ & $\int 0 x$ & $\int 0 x$ & $\int 0 x$ & $\int 0 x$ & Sox & Sox & $\int 0 x$ & $\int 0 x$ & fox & fox & $\int 0 x$ & Sox & 50x & Sox & Sox & $\int 0 x$ & $\int 0 x$ \\
\hline 89. & tail & |دومب & dum & dum & dum & dum & dum & dum & dum & dum & dum & dum & dum & dum & dum & dum & \begin{tabular}{|l|} 
dom \\
\end{tabular} & dum & dum \\
\hline 90. & feather & |ֶِ & pa:r & pa:r & pa:r & pa:r & pair & pa:r & pa:r & pa:r & pa:r & pa:r & pa:r & pa:r & pa:r & pa:r & pa: & pa:r & pa:r \\
\hline 91. & $\begin{array}{l}\text { hair (on } \\
\text { head) }\end{array}$ & مو & mu:j & mu: & mu: & mu: & mu:j & mu: & mu: & $\mathrm{mu}$ & mu: & mu: & mu:j & my: & mu:j & my: & mu: & mu: & mu: \\
\hline 92. & head & سر & \begin{tabular}{|l|} 
sa:r \\
\end{tabular} & sa:r & sa:r & sa:r & sa:r & \begin{tabular}{|l|} 
sair \\
\end{tabular} & ka'la & ka'la & sa:r & sa:r & sa:r & sa:r & sa:r & sa:r & sa:r & sa:r & sa:r \\
\hline 93. & ear & كوش & go: $\int$ & go: $\int$ & go: $\int$ & go: $\int$ & go:S & go:S & go: $\int$ & go: $\int$ & go: $\int$ & go: $\int$ & go: & gø:S & go:S & gø:S & go:S & go: $\int$ & go: $\int$ \\
\hline 94. & nose & بينى & bi:'ni: & bi:'ni: & bi:'ni: & bi:'ni: & bi:'ni: & bi:'ni: & bi:'ni: & bi:'ni: & bi:'ni: & bi:'ni: & bi:'ni: & bi:'ni: & bi:'ni: & ba'ni: & ba'ni: & bi'ni: & bi:'ni: \\
\hline 95. & eye & |جشڤ & $\mathrm{t} \int \curvearrowright \int \mathrm{m}$ & $\mathrm{t} \int \curvearrowright \int \mathrm{m}$ & $\mathrm{t} \int \partial \mathrm{\int m}$ & $\mathrm{t} \int \mathrm{\partial} \mathrm{m}$ & $\mathrm{t} \int \mathrm{\partial} \mathrm{Sm}$ & $\mathrm{t} \int 2 \int \mathrm{m}$ & $\mathrm{t} \int \mathrm{\partial} \mathrm{sm}$ & $\mathrm{t} \int \partial \mathrm{\int m}$ & $\mathrm{t} \int \mathrm{\rho} \mathrm{Sm}$ & $\mathrm{t} \int \partial \int \mathrm{m}$ & $\mathrm{t} \int \curvearrowright \int \mathrm{m}$ & $\mathrm{t} \int \curvearrowright \int \mathrm{m}$ & $\mathrm{t} \int \curvearrowright \int \mathrm{m}$ & $\mathrm{t} \mathrm{Sa} \mathrm{sm}$ & $\mathrm{t} \int \mathrm{a} \mathrm{am}$ & $\mathrm{t} \int \partial \mathrm{fm}$ & $\mathrm{t} \int \mathrm{a} \int \mathrm{m}$ \\
\hline 96. & mouth & دهن & da:n & da:n & da:n & da:n & da:n & da'han & da'han & da'han & da'han & da:n & da:n & da:n & da:n & da:n & da:n & da:n & da:n \\
\hline 97. & tooth & |دندان & dan'don & dan'don & dan'don & dan'don & dan'don & dan'don & dan'dun & dan'don & dan'dun & dan'don & dan'don & dan'dun & dan'don & dan'du & dan'don & dan'dun & dan'don \\
\hline 98. & tongue & زبان & \begin{tabular}{|l|} 
za'bon \\
\end{tabular} & zu:n & zuin & za'bon & za'bon & \begin{tabular}{|l|l} 
za'bon \\
\end{tabular} & zu:n & zu:n & zu:n & zu:n & \begin{tabular}{|l|l} 
za'bon \\
\end{tabular} & zu:n & \begin{tabular}{|l|l} 
za'bon \\
\end{tabular} & zu: & zu: & zun & \begin{tabular}{|l} 
za'bon \\
\end{tabular} \\
\hline 99. & foot & ״ֶاى & poj & po:'tfyk & po:'tfyk & po: & poj & po & po'tfyk & po & po'tfyk & po & poj & po & po & po & po & po'tfyk & po \\
\hline 100 & knee & زانو & zo'nu & zo'nu & zo'ni & zo'nu & zo'nu & zo'nu & zo'ni & zo'ni & zo'nu & zo'nu & zo'nu & zo'nY & zo'nu & zo'nu & zo'nu & zo'nu & zo'nu \\
\hline 101 & hand & دست & dest & dest & dest & dast & dast & dest & dəst & dast & dest & dest & dest & dest & dest & dest & dəst & dast & dast \\
\hline 102 & finger & انكثتت & an'gust & pan'dza & pan'dza & pan'dza & an'guft & ay'guft & kəlk & kelk & tfa'lik & tfa'lek & an'guft & pan'dza & \begin{tabular}{|l|} 
t Ja'lek \\
\end{tabular} & lik & lik & pan'dza & pan'dza \\
\hline 103 & belly & شكم & Sə'kam & Sə'kam & Sə'kam & Sə'kam & Sə'kam & Sə'kam & Sə'kam & Sə'kam & So'kam & So'kam & Sə'kam & Sə'kam & So'kam & Sə'kam & So'kam & So'kam & \begin{tabular}{|l|} 
Sa'kam \\
\end{tabular} \\
\hline
\end{tabular}




\begin{tabular}{|c|c|c|c|c|c|c|c|c|c|c|c|c|c|c|c|c|c|c|c|}
\hline 104 & neck & ي| كردن & gar'dan & gar'an & gar'an & gar'dan & gar'dan & \begin{tabular}{l|l} 
gar'dan \\
\end{tabular} & mak & gar'dan & gar'dan & ga'ran & gar'dan & ga'ran & gar'dan & ga'ra & ga'ra & ga'ra & gar'dan \\
\hline 105 & heart & |قلب & Qalp & dəl & dəl & qalp & dəl & dəl & dəl & qalp & dəl & dəl & qalp & dəl & dəl & dəl & dəl & dəl & dəl \\
\hline 106 & liver & |جكر & dzı'gar & \begin{tabular}{|l|} 
dzI'gar \\
\end{tabular} & dż'gar & dzI'gar & dzI'gar & dzı'gar & dzI'gar & dzI'gar & dzı'gar & dzI'gar & dzı'gar & dzı'gar & dzı'gar & dzi'gar & dzı'gar & dzI'gar & dzi'gar \\
\hline 107 & back & |بوشت & pust & ar'qa & ar'qa & ar'qa & puft & pust & puft & pyst & ar'qa & ar'qa & puft & ar'qa & ar'qa & ar'qan & a'qip & pust & a'qip \\
\hline 180 & drink $N P$ & 'ميخورد & 'mexora & 'mexэra & 'mехэга & 'mexэra & 'mexэra & 'mexэra & 'xurma & 'xurmej & xur & 'mexэra & 'mехэга & \begin{tabular}{|l|} 
XYr \\
\end{tabular} & \begin{tabular}{|l|}
$\mathrm{XYr}$ \\
\end{tabular} & \begin{tabular}{|l|} 
'xy:rəma \\
\end{tabular} & 'mexэra & 'mexэra & 'mexora \\
\hline 108 & drink $P$ & خورد & xurt & xurt & xurt & xurt & xurt & xurt & XYr & xurt & \begin{tabular}{|l|} 
'boxur \\
\end{tabular} & xurt & xurt & \begin{tabular}{|l|} 
XYr \\
\end{tabular} & XYrt & XY:Г & XYr & XYr & xurt \\
\hline 100 & eat $N P$ & '|ميخورد & 'mexэra & 'mexэra & 'mехэга & 'mexэra & 'mexэra & 'mexэra & 'xurma & 'xurmej & xur & 'mexэra & 'mexэra & XYr & XYr & 'XY:rəma & 'mexэra & 'mexэra & 'mexэra \\
\hline 109 & eat $P$ & خورد & xurt & xurt & xurt & xurt & xurt & xurt & $\mathrm{XYS}$ & xurt & 'boxur & xurt & xurt & XYr & XYst & XY:Г & XYr & XYr & xurt \\
\hline 110 & bite $N P$ & |قبزنه & \begin{tabular}{|l|} 
qab \\
'mezana
\end{tabular} & \begin{tabular}{|l|} 
'megira \\
\end{tabular} & 'megira & $\begin{array}{l}\text { qap } \\
\text { 'mezana }\end{array}$ & $\begin{array}{l}\text { qab } \\
\text { 'mezana }\end{array}$ & 'megira & 'megira & 'megira & \begin{tabular}{|l|} 
qab \\
'mezana
\end{tabular} & 'megira & $\begin{array}{l}\text { aab } \\
\text { mezana }\end{array}$ & 'megira & 'bəkant & 'megira & 'megaza & \begin{tabular}{|l|} 
qab \\
'mezana
\end{tabular} & 'megira \\
\hline & bite $P$ & قب زد & qab zat & \begin{tabular}{|l|} 
'bagirift \\
\end{tabular} & 'bagirift & qap zat & qab zat & gi'rift & gi'rift & gI'rIft & qab zat & gI'rIft & qab zat & 'bəgirıft & 'bəkant & 'gorift & ga'zit & qab zat & gi'rift \\
\hline 11 & see $N P$ & |' ميبيد & 'mibina & 'mıbina & 'mıbına & 'mıbına & 'mıbına & 'mıbına & 'mıbına & 'mıbına & 'mıbına & 'mıbına & 'mıbına & 'bədi & 'mibına & 'medi: & 'mibına & 'mebina & 'mebina \\
\hline 1115 & see $P$ & |ديد & ditt & di:t & di:t & di:t & di:t & di:t & ditt & di:t & ditt & ditt & ditt & 'bədi & ditt & 'bədi: & 'bədi & ditt & ditt \\
\hline 112 & hear $N P$ & |ميشنود & \begin{tabular}{|l|} 
'mI- \\
Snawa
\end{tabular} & \begin{tabular}{|l|} 
'mI- \\
Snawa
\end{tabular} & $\begin{array}{l}\text { 'mI- } \\
\text { Snawa }\end{array}$ & $\begin{array}{l}\text { 'mI- } \\
\text { Snawa }\end{array}$ & $\begin{array}{l}\text { 'mI- } \\
\text { Snawa }\end{array}$ & $\begin{array}{l}\text { 'mI- } \\
\text { Snawa }\end{array}$ & $\begin{array}{l}\text { 'mI- } \\
\text { Snawa }\end{array}$ & $\begin{array}{l}\text { 'mI- } \\
\text { Snawa }\end{array}$ & $\begin{array}{l}\text { 'mI- } \\
\text { Snawa }\end{array}$ & $\begin{array}{l}\text { 'mI- } \\
\text { Snawa }\end{array}$ & $\begin{array}{l}\text { 'mI- } \\
\text { Snawa }\end{array}$ & bəSnawi & $\begin{array}{l}\text { 'mI- } \\
\text { Snawa }\end{array}$ & $\begin{array}{l}\text { 'bofnaw } \\
\text { uma }\end{array}$ & 'Sənawi & \begin{tabular}{|l} 
'mI- \\
Snawa
\end{tabular} & \begin{tabular}{|l|} 
'me- \\
Snawa
\end{tabular} \\
\hline & hear $P$ & شنيد & Su'nit & \begin{tabular}{|l|} 
'Sonawit \\
\end{tabular} & 'Sonawit & 'Sənawit & 'Sənawit & Su'nit & 'Sonawit & Su'nit & \begin{tabular}{|l|} 
'Sənawit \\
\end{tabular} & 'Sənawit & Su'nit & 'Sənawit & Su'nit & 'bəSnawi & 'Sənawi & 'Sənawit & 'Sənawit \\
\hline 113 & know $N P$ & '|" ميفحمد & 'mefoma|' & meduna & 'meduna & 'meduna & 'mefoma & mefoma & 'meduna & 'meduna & 'meduna & 'meduna & mefoma & bədunist & meduna & \begin{tabular}{|l|} 
'bo- \\
dunama
\end{tabular} & meduna & 'meduna & meduna \\
\hline & know $P$ & فحميد & fo'mit & 'dunist & 'dunist & 'dunist & fo'mit & fo'mit & 'dunist & 'donist & bədunist & 'donist & fo'mit & bədunist & 'dunist & \begin{tabular}{|l|} 
'bədunist \\
\end{tabular} & 'bədunist "' & 'bədunist & 'dunist \\
\hline 14 & sleep $N P$ & ' ميكو ند & \begin{tabular}{|l|l} 
xaw & x \\
'mekuna & 11 \\
\end{tabular} & \begin{tabular}{|l|} 
xaw \\
mekuna \\
\end{tabular} & $\begin{array}{l}\text { xaw } \\
\text { kuna'mi }\end{array}$ & $\begin{array}{l}\text { xaw } \\
\text { 'mekuna }\end{array}$ & $\begin{array}{l}\text { xaw } \\
\text { 'mekuna } \\
\end{array}$ & $\begin{array}{l}\text { Xaw } \\
\text { mekuna } \\
\end{array}$ & $\begin{array}{l}\text { xaw } \\
\text { 'mekuna }\end{array}$ & $\begin{array}{l}\text { xaw } \\
\text { 'mekuna }\end{array}$ & \begin{tabular}{|l|} 
xaw \\
'mekuna \\
\end{tabular} & \begin{tabular}{|l|} 
xaw \\
'mekuna \\
\end{tabular} & \begin{tabular}{|l|} 
xaw \\
mekuna \\
\end{tabular} & xow kar & $\begin{array}{l}\text { xaw } \\
\text { mekuna }\end{array}$ & xaw kar & $\begin{array}{l}\text { xaw } \\
\text { 'mekuna }\end{array}$ & xəw kar & xow kar \\
\hline 114 & sleep $P$ & كرد & xaw kat & xaw kat & xaw kat & xaw kat & xaw kat & xaw kat & xaw kat & xaw kat & xaw kat & xaw kat & xaw kat & xow kar & xaw kat & xaw Si: & xaw kat & xow kar & xow kar \\
\hline 115 & $\operatorname{die} N P$ & |'ميُهُرد & 'memura & 'bəmys & 'bəmyr & 'memura & 'memura & memura & $\begin{array}{l}\text { 'bo- } \\
\text { myrama }\end{array}$ & 'memura & 'memura & 'bəmyr & memura & 'bəmys & memura & 'bəmys & memura & mur & memura \\
\hline & $\operatorname{die} P$ & مُرْمُ & murt & 'bəmys & 'bəmys & murt & murt & murt & 'bəmys & 'bəmys & 'bəmyr & 'bəmys & murt & 'bəmys & 'bəmyr & 'bəmys & 'bəmyr & 'bəmur & murt \\
\hline & think $N P$ & 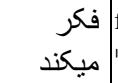 & \begin{tabular}{|l|l|} 
fəkr \\
'mekuna
\end{tabular} & \begin{tabular}{|l|} 
tfurd \\
'mezana \\
\end{tabular} & $\begin{array}{l}\text { tfurd } \\
\text { 'zanamə }\end{array}$ & $\begin{array}{l}\text { fəkr } \\
\text { 'mekuna }\end{array}$ & $\begin{array}{l}\text { fəkr } \\
\text { 'mekuna }\end{array}$ & $\begin{array}{l}\text { fəkr } \\
\text { 'mekuna }\end{array}$ & $\begin{array}{l}\text { tfurd } \\
\text { 'mezana }\end{array}$ & $\begin{array}{l}\text { tfurd } \\
\text { 'mezana }\end{array}$ & \begin{tabular}{|l|} 
tfurd \\
'mezana \\
\end{tabular} & $\begin{array}{l}\text { tfurd } \\
\text { 'mezana }\end{array}$ & $\begin{array}{l}\text { fakr } \\
\text { mekuna }\end{array}$ & 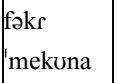 & \begin{tabular}{|l|} 
tfurd \\
'mezana \\
\end{tabular} & \begin{tabular}{|l|} 
tfurd \\
'mezana
\end{tabular} & \begin{tabular}{|l|} 
tfurd \\
'mezana \\
\end{tabular} & $\begin{array}{l}\text { tfurd } \\
\text { 'mezana }\end{array}$ & \begin{tabular}{|l} 
tfurd \\
'mezana
\end{tabular} \\
\hline 116 & think $P$ & فكر كرد & fokr kat th & $\begin{array}{l}\text { tfurd } \\
\text { mezanat } \\
\end{array}$ & tfurd zo & fəkr kat & fəkr kat & fəkr kat & tfurd zat & t furd zat & tfurd zo & tfurd zat & fəkr kat & fəkr kat & tfurd zat & \begin{tabular}{|l|} 
tfurd zo \\
\end{tabular} & \begin{tabular}{|l|} 
t surd zo \\
\end{tabular} & tfurd zo & tfurd zo \\
\hline & $\begin{array}{l}\text { say/speak } \\
N P\end{array}$ & |ميزّ" & \begin{tabular}{|l|} 
gap \\
'mezana \\
\end{tabular} & \begin{tabular}{|l|} 
gap \\
'mezana \\
\end{tabular} & $\begin{array}{l}\text { gap } \\
\text { 'zanamə }\end{array}$ & $\begin{array}{l}\text { gap } \\
\text { 'mezana }\end{array}$ & $\begin{array}{l}\text { gap } \\
\text { 'mezana }\end{array}$ & \begin{tabular}{|l|} 
gap \\
'mezana
\end{tabular} & $\begin{array}{l}\text { gap } \\
\text { 'mezana }\end{array}$ & $\begin{array}{l}\text { gap } \\
\text { 'mezana }\end{array}$ & \begin{tabular}{|l|} 
gap \\
'mezana \\
\end{tabular} & \begin{tabular}{|l|} 
'naqəl \\
'mekuna \\
\end{tabular} & \begin{tabular}{|l|} 
naqəl \\
mekuna
\end{tabular} & $\begin{array}{l}\text { naqəl } \\
\text { mekuna }\end{array}$ & $\begin{array}{l}\text { naqəl } \\
\text { mekuna }\end{array}$ & \begin{tabular}{|l|} 
'naqəl \\
'mekuna \\
\end{tabular} & $\begin{array}{l}\text { naqəl } \\
\text { mekuna }\end{array}$ & \begin{tabular}{|l|} 
naqəl \\
'mekuna \\
\end{tabular} & $\begin{array}{l}\text { naqəl } \\
\text { mekuna }\end{array}$ \\
\hline 117 & $\begin{array}{l}\text { say/speak } \\
P\end{array}$ & كَب زد & gap zat & gap zat & gap zo & gap zat & gap zat & gap zat & gap zow & gap zo & gap zo & $\begin{array}{l}\text { 'naqəl } \\
\text { kat }\end{array}$ & \begin{tabular}{|l|} 
'naqəl \\
kat
\end{tabular} & \begin{tabular}{|l|} 
'naqəl \\
kat
\end{tabular} & \begin{tabular}{|l|} 
'naqəl \\
kat
\end{tabular} & \begin{tabular}{|l|} 
'naqəl \\
kat \\
\end{tabular} & \begin{tabular}{|l} 
'naqəl \\
kat
\end{tabular} & $\begin{array}{l}\text { 'naqəl } \\
\text { kat }\end{array}$ & \begin{tabular}{|l|} 
'naqəl \\
kat
\end{tabular} \\
\hline 118 & kill & '|"ميكثد & 'mekufa & 'mekJa & 'mekfa & 'mekJa & 'mekJa & 'mekufa & 'mekfa & 'mekufa & 'mekufa & 'mekufa & 'mekusa & 'bəkuft & 'mekufa & \begin{tabular}{|l|} 
'bə- \\
kJəmə
\end{tabular} & $\begin{array}{l}\text { 'bə- } \\
\text { kfəmə }\end{array}$ & 'mekJa & 'mekfa \\
\hline & kill & كثت & kuSt & kvSt & kuft & kuft & kuft & kuft & kuft & kuft & kuft & kuft & kuft & kuft & kuft & 'bəkuft & 'bəkuft & kuft & 'bokufta \\
\hline 119 & red & |سرخ & surx & surx & surx & surx & surx & surx & surx & surx & surx & surx & surx & surx & surx & surx & surx & surx & surx \\
\hline
\end{tabular}




\begin{tabular}{|c|c|c|c|c|c|c|c|c|c|c|c|c|c|c|c|c|c|c|c|}
\hline 120 & green & سبز & Sabs & sabs & sabs & sabs & sabs & sabs & saws & sabs & sabs & sabs & sabs & saws & sabs & saws & sabs & saws & sabs \\
\hline 121 & yellow & زرد & zart & zart & zart & zart & zart & zart & zart & zart & zart & zart & zart & zart & zart & zart & zart & zart & zart \\
\hline 122 & white & سفيد & sa'fet & sa'fet & sa'fet & sa'fet & sa'fet & sa'fet & sfet & sa'fet & sa'fet & sa'fet & sa'fet & sa'fet & sa'fet & sa'fet & sa'fet & sfe:t & sa'fet \\
\hline 123 & black & سياه & sjo & sjo & sjo & sjo & sjo & sjo & sja & sja & sjo & sjo & sjo & sja & sjo & sja & sjo & sja & sja \\
\hline 124 & warm & كرم & garm & garm & garm & garm & garm & garm & garm & garm & garm & garm & garm & garm & garm & garm & garm & garm & garm \\
\hline 125 & cold & سرد & sart & xu'nuk & xu'nuk & xu'nuk & xu'nuk & xu'nuk & xu'nuk & xu'nuk & xu'nuk & xu'nuk & sart & xu'nuk & xu'nuk & xu'nuk & xu'nuk & xu'nuk & xu'nuk \\
\hline 126 & full & ير & pur & pur & pur & pur & pur & pur & pur & por & pur & pur & pur & luq & pur & luq & luq & pur & be:'kor \\
\hline 127 & empty & خالى & xo'li & xo'li & xo'li & xo'li & xo'li & xo'li & be'kor & xo'li & xo'li & xo'li & xo'li & be'kor & xo'li & be:'kor & xo'li & be:'kor & xo'li \\
\hline 128 & new & نو & Naw & naw & naw & naw & naw & naw & naw & naw & naw & naw & naw & naw & naw & naw & naw & naw & naw \\
\hline 129 & old & كهنه & ko:'na & ku:'na & ku:'na & ku:'na & ko:'na & ko:'na & ko:'na & ko:'na & ko:'na & ko:'na & ko:'na & ku:'na & ko:'na & ku:'na & ko:'na & ku:'na & ko:'na \\
\hline 130 & round & كرد & gurt & gurt & gurt & gurt & gurt & gurt & gurt & gurt & gurt & gurt & gurt & gurt & gurt & gurt & gurt & gurt & gurt \\
\hline 131 & dry & خشى & $\mathrm{xu} \int \mathrm{k}$ & xufk & qoq & $\mathrm{xu} \int \mathrm{k}$ & xufk & xufk & xufk & xufk & qoq & $\mathrm{xu} \int \mathrm{k}$ & qoq & xufk & qoq & $\mathrm{q}$ q & qoq & qoq & $\mathrm{q}$ q \\
\hline 132 & wet & تر & ta:r & ta:r & ta:r & tair & ta:r & ta:r & ta:r & ta:r & ta:r & ta:r & ta:r & ta:r & ta:r & ta:r & ta:r & ta:r & ta:s \\
\hline 133 & good & خوب & xup & xup & xup & xup & xup & xup & xup & xup & xup & xup & xup & xup & xup & xup & xup & xup & xum \\
\hline 134 & bad & بد & ba:t & ba:t & bait & bait & bait & bait & $\mathrm{zY} \int \mathrm{t}$ & zySt & ba:t & $\mathrm{zY} \int \mathrm{t}$ & bait & ba:t & ba:t & ta'wa & ta'wa & gan'da & ta'wa \\
\hline 135 & mother & مادر & mo'da:r & mo'da: & na'nik & na'nik & mo'da: & u'ma & u'ma & mo'da: & mu'ma & mu'ma & mo'da: & mu'ma & mu'ma & u'ma & $u^{\prime} m a$ & mu'ma & mu'ma \\
\hline 136 & father & يגנ & \begin{tabular}{|l|} 
pa'da: \\
\end{tabular} & pa'da:r & bo'ba & bo'ba & pa'da: & bo'ba & bo'ba & pa'da: & a'ka & bo'ba & pa'da:r & bo'ba & bo'ba & bo'ba & bo'ba & bo'ba & do'da \\
\hline 137 & husband & إنو هر & \begin{tabular}{|l|} 
Saw'har \\
\end{tabular} & fu: & SU: & SU: & Su: & Su: & Su: & SU: & Su: & fu: & Saw'har & $\int \mathrm{Y}:$ & Su: & Sø: & Sø: & Su: & Su: \\
\hline 138 & wife & خانم & xo'nım & zan & zan & zan & zan & za'nak & zan & xo'num & zan & za'nak & xo'nım & zan & zan & za'nak & zan & zan & zan \\
\hline 139 & child & طفل & tofl & $\begin{array}{l}\text { tfa- } \\
\text { 'ye:ryk }\end{array}$ & kø'dak & $\begin{array}{l}\text { tfa- } \\
\text { 'yeryk }\end{array}$ & $\begin{array}{l}\text { ţə- } \\
\text { 'yeryk }\end{array}$ & kø'dak & $\begin{array}{l}\text { tfə- } \\
\text { ye:'ryk }\end{array}$ & $\begin{array}{l}\text { t5ə- } \\
\text { ye:'ryk }\end{array}$ & $\begin{array}{l}\text { tfo- } \\
\text { ye:'ryk }\end{array}$ & $\begin{array}{l}\text { tfo- } \\
\text { ye'ryk }\end{array}$ & tofl & gø'lak & $\begin{array}{l}\text { tfə- } \\
\text { ye:'ryk }\end{array}$ & $\begin{array}{l}\text { tfə- } \\
\text { ye:'ryk }\end{array}$ & $\begin{array}{l}\text { tfo- } \\
\text { 'ye:ryk }\end{array}$ & $\begin{array}{l}\text { tfa- } \\
\text { ye:'ryk }\end{array}$ & $\begin{array}{l}\text { tfo- } \\
\text { ye:'ryk }\end{array}$ \\
\hline 140 & son & بجه & ba'tfa & ba'tfa & ba'tfa & ba'tfa & ba'tfa & ba'tfa & ba'tfa & ba'tfa & ba'tfa & ba'tfa & ba'tfa & ba'tfa & ba'tfa & ba'tfa & ba'tfa & ba'tfa & ba'tfa \\
\hline 141 & daughter & | دختر & dux'ta:c & dux'ta:s & dux'ta: & dux'ta: & dux'ta: & dux'ta:r & dux'ta: & dux'ta:r & dux'ta:r & dux'ta:r & dux'ta: & dux'ta: & dux'ta:r & dux'ta:r & dux'ta:c & dux'ta:c & dux'ta: \\
\hline 142 & village & قريه & qar'ja & qar'ja & qar'ja & qar'ja & qar'ja & qar'ja & qar'ja & qar'ja & qar'ja & qar'ja & qar'ja & qar'ja & qar'ja & qar'ja & qar'ja & qar'ja & qar'ja \\
\hline 143 & house & خانه & xo'na & xo'na & xu'na & xo'na & xo'na & xo'na & xu'na & xo'na & xu'na & xu'na & xo'na & xo'na & xo'na & xu'na & xo'na & xu'na & xu'na \\
\hline 144 & hammer & |جشش & t ta'kuS & bolı'qa & bolı'qa & boli'qa & bolr'qa & bolı'qa & boli'qa & boli'qa & bolı'qa & boli'qa & t fa'kus & bolı'qa & t $\mathrm{a}^{\prime} \mathrm{kuS}$ & boli'qa & bolı'qa & bolı'qa & bolı'qa \\
\hline 145 & knife & جاقو & $\mathrm{t} \int \mathrm{o}^{\prime} \mathrm{qu}$ & kor'tfa & kor'tfa & kor'tfa & kor'tfa & kor'tfa & kor'tfa & kor'tfa & kor'tfa & kor'tfa & tfo'qu & kor'tfa & kor'tfa & tfo'qu & kor'tfa & tfaw'qu & kor'tfa \\
\hline 146 & $\begin{array}{l}\text { path/ } \\
\text { road }\end{array}$ & |بياده رو & $\begin{array}{l}\text { pjoda- } \\
\text { 'raw } \\
\end{array}$ & $\mathrm{ra}$ & ra & юr & รо & ra & $\begin{array}{l}\text { rae pjo- } \\
\text { da'raw }\end{array}$ & $\begin{array}{l}\text { pjoda- } \\
\text { 'raw } \\
\end{array}$ & pjoda'ra & pjoda'ra & $\begin{array}{l}\text { pjoda- } \\
\text { 'raw } \\
\end{array}$ & $\begin{array}{l}\text { pjoda- } \\
\text { 'raw } \\
\end{array}$ & $\begin{array}{l}\text { pjoda- } \\
\text { 'raw } \\
\end{array}$ & pjoda'ra & $\begin{array}{l}\text { roe } \\
\text { pjo'da }\end{array}$ & pjoda'ra & го \\
\hline 147 & name & نام & no:m & no:m & nu:m & no:m & no:m & no:m & nuim & no:m & nu:m & nu:m & no:m & nu:m & nэ:m & nu:m & nu:m & nuim & no:m \\
\hline
\end{tabular}




\section{Appendix B: Village Elder Questionnaire}

I. Interview Data

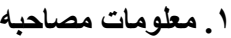

1. Researcher

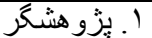

2. Date

3. Location

4. Language of Interview

II. Personal Data of Informant

Y ا ـ معلومات شخضى جواب دهنده

1. ID

2. Name of Informant

3. Gender of Informant

4. Place of Birth

5. Residence (now/others)

6. Mother Tongue

7. Father's Mother Tongue

8. Mother's Mother Tongue

9. Spouse's Mother Tonue

10. Education Level

11. Profession, where

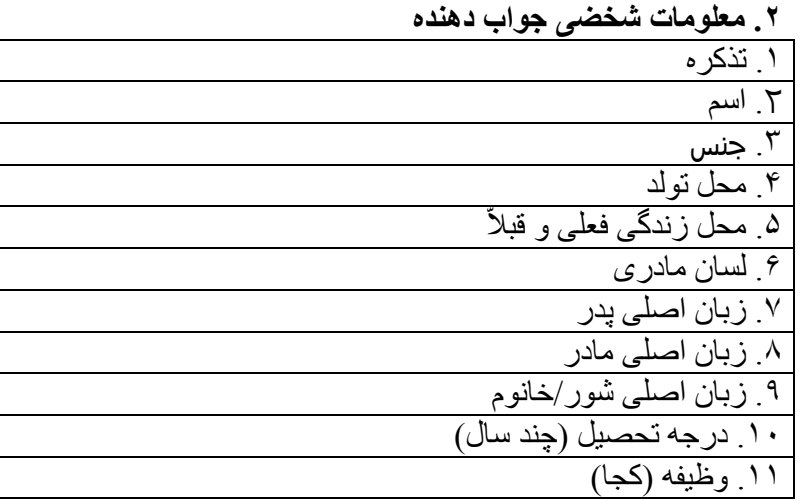

III. Village Data

r آ. معلومات قريه

1. How many houses are in the village?

2. How many people do usually live in a house?

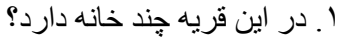

3. How many people do live in the village?

4. How is the village organized? Who is the head?

5. What language do the elders in your community use with each other? With the people?

6. Which language(s) do you speak with gov't officials?

IV. School Data

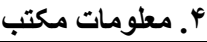

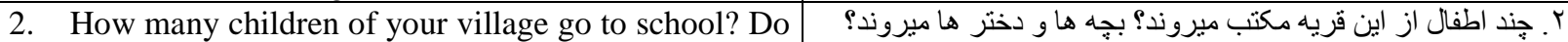
boys and girls go?

3. How big is this school? Up to which grade does it $\quad$ اين مكتب جند شاكرد دارد؟ و تا كدام صنف هست؟ go?

4. What people do the teachers belong to? What is their mother tongue?

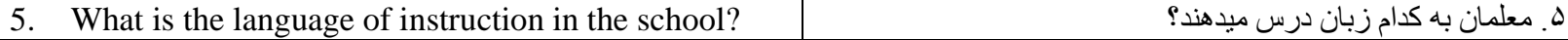

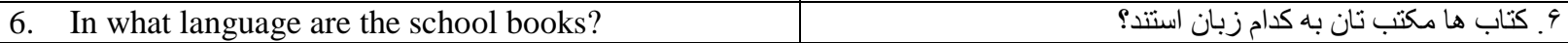

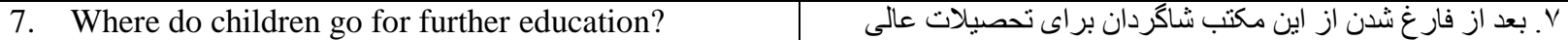

كجا ميروند؟

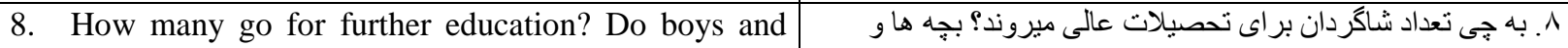
girls go?

9. How many of the adults are literate in your village?

V. Health

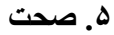

1. Where do people go when they are sick?

2. Where is the nearest hospital, clinic and pharmacy? 


\begin{tabular}{|c|c|}
\hline 3. How do people go? & ؟. مردم كه مريض هستند جطور آنجا ميروند؟ \\
\hline 4. How long does it take? & r. جقدر وقت را ميكرد؟؟ \\
\hline $\begin{array}{l}\text { 5. What are the common sicknesses people suffer } \\
\text { from? }\end{array}$ & ه. كدام مريضى را مردم زيادتر دارند؟ \\
\hline
\end{tabular}

VI. Basic Licing Conditions

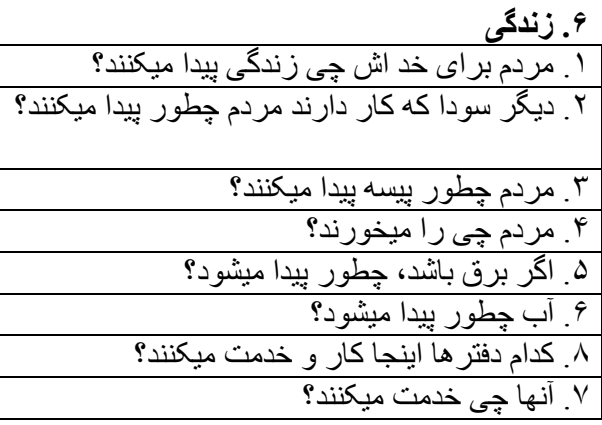

\section{Appendix C: Sociolinguistic Group Questionnaire ${ }^{7}$}

I. Interview Data

1. Researcher

2. Date

3. Location

4. Language of Interview

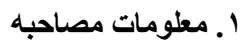

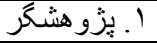

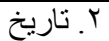

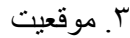

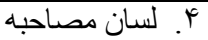

\section{Language Area}

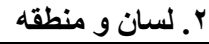

1. What language do you speak in this village?

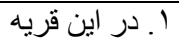

2. What do you call your dialect?

3. Are there any people in your village who don't speak Darwāzi?

4. In which other villages do people speak Darwāzi? How many people speak Darwāzi in those villages?

5. Where do people speak Darwāzi differently?

6. Do you always understand it well?

7. Where do people speak Darwāzi most sweet/beautiful? Least sweet/beautiful?

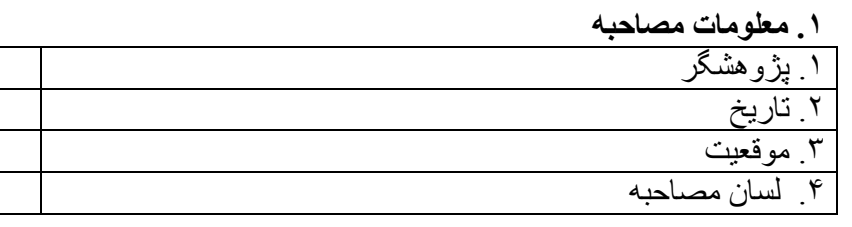

III. Language and Family

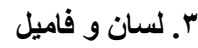

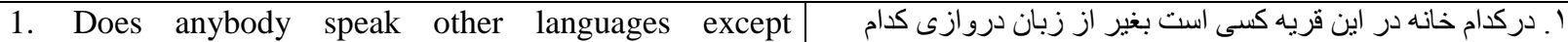
Darwāzi in any home? Who? With Whom? Why?

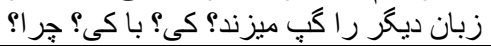

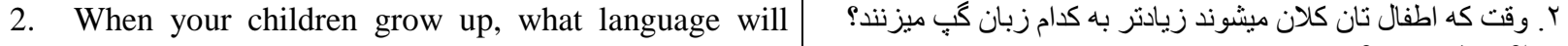
they use the most? Why? Are you happy with that?

3. When your grand children grow up, what language will they use the most? Why? Are you happy with that?

4. Are there any wives in the village who are not Darwāzi? If yes: What language do husband and wife speak together? Their children?

5. Is there any women from the village given for 1 در اين قريه دختر عروسى كرده به قريه كه دروازى نيست؟

${ }^{7}$ This is the questionnaire used in the Darwāzi villages. In the Tangshewi speaking villages a slightly different one was used: 'Darwāzi' is replaced by 'Tangshewi' and vice versa. 
marriage outside Darwāz? If yes: What language do they speak with their husbands? Their children?

6. Would you let your son marry someone who speaks only Shughni/Dari/ Pashto/Tangshew?

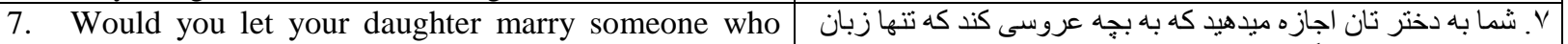
speaks only Shughni/Dari/ Pashto/Tangshew?

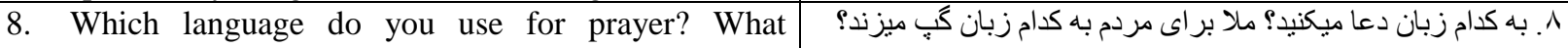
language does the Mullah use for preaching?

IV. Language, Travel and Trade

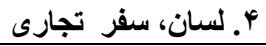

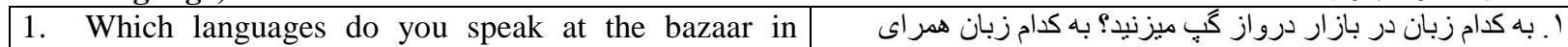

Darwāz (in case there is one)? Which languages do you speak with merchants who come to the village (in case there are any)?

2. Where do people from here travel to? How often? How long? For what occasions? What language do you use there?

3. military service? Where? How long? What language did you use there?

4. Do people come from other places to visit you? How often? How long? For what occasions? What كدام زبان هار بشا بشتر استفاده ميكند؟؟ language do they use?

5. D. مردم از اين قريه بيش تنكثيو رفنتن؟ يا آنها را اينخا ديدند؟بان meet them here? How is their language different?

6. Did people travel to the Darwāzi in Tajikistan? Or did you meet them here? How is their language با آنها را اينخا ديدند؟ زبان اثشان جى فرق دارد؟؟ different?

7. Where does Darwāzi come from? Where was it $\quad$ زبان دروازى از كجا آمده؟ اول در كجارواج بود؟؟ spoken first?

8. Has ever anyone made fun of you because of your $\quad$ كس سر شما خنده كرد از خاطر زبان شما؟ كى بود؟ language? Who?

V. Language, Children and Education

هـ لسان، اطفال و تحصبل

1. When children start school do they already know $\quad$ وقت كه اطفال نو مكتب ميروند زبان درى را ياد كرفتند؟ Dari?

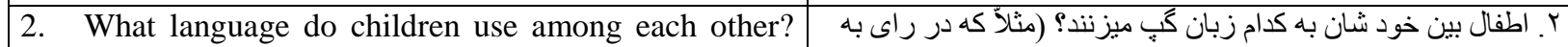
E.g. on the way to school?

3. Does the teacher help your children in Darwāzi in $\quad$ r. معلم اطفال را به زبان دروازى در صنف كمك ميكن؟؟ class?

4. What language do teachers speak with the students outside of class?

5. At what grade do your children understand Dari $\quad$ ه. well?

6. Would you prefer your children to learn reading and writing in Dari first, or in Darwāzi first and later in Dari? Why?

VI. Literacy and Media

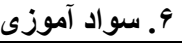

1. In what language do people read books?

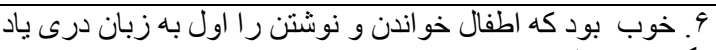

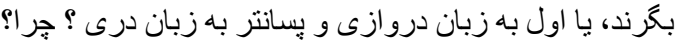

1 أ. مردم به كدام زبان كتاب ر ا ميخو انند؟ 
2. Would you like books in Darwāzi? What kind of

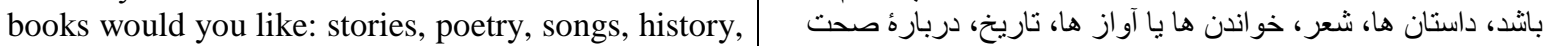
health education, other?

3. Would you spend money to buy books in Darwāzi?

4. What would be the best Darwāzi dialect to produce literature in? Why?

5. Do you listen to the radio? In what language?

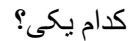

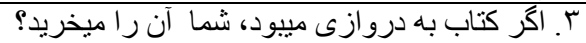

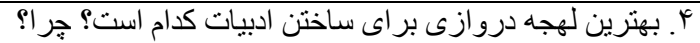
ه. شما راديو را ميشنويد؟ به كدام زبان؟

VII. Intelligibility

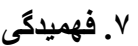

1. How well do older men in the village understand مرد ريش سفيد در اين قريه جقدر درى ميفهوند؟ زن سر سفيد Dari? Older women?

2. How well do adult men in the village understand مرد ميانه سال در اين قريه جقدر درى ميفهيند؟ زن ميانه سال Dari? Adult women?

3. How well do children in the village understand Dari?

4. How well do older men in the village understand مرد ريش سفيد در اين قريه جقدر تاجك ميفهيند؟ زن سر سفيد Tajik? Older women?

5. How well do adult men in the village understand هُ مرد ميانه سال در اين قريه جقدر تاجك ميفهمند؟ زن ميانه سال Tajik? Adult women?

6. How well do children in the village understand Tajik?

7. What is easier to understand, Dari or Tajik? $\quad$ V. كدام زبان به دروازى نزديكتر است كه شما ميفهيد، درى يا تاجك؟

VIII. Perceived Benefit

1. How useful is Darwāzi for you in respect of -

- getting jobs

- higher education

- communication with other communities

- gaining respect in your community?

2. How useful is Dari for you in respect of -

- getting jobs

- higher education

- communication with other communities

- gaining respect in your community?

3. How useful is Tajik for you in respect of -

- getting jobs

- higher education

- communication with other communities

- gaining respect in your community?

4. How important is the Darwāzi language to you?

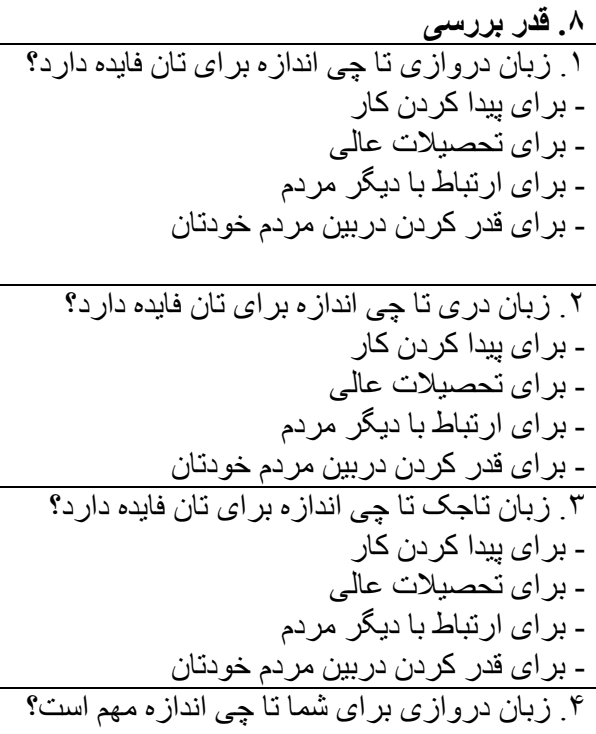

\section{Appendix D: Stories for RTTs (with Breaks) and Questionnaire}

\section{RTT Questionnaire}

\section{Pre-Testing Data}

\begin{tabular}{|c|c|}
\hline 1. ID & ا. تذكره \\
\hline 2. Researcher & 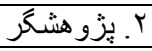 \\
\hline 3. Date & "r. تاريخ \\
\hline 4. Location & r. موقعيت \\
\hline
\end{tabular}




\begin{tabular}{|c|c|}
\hline 5. Name of Informant & ه. اسم جو اب دهنده \\
\hline 6. Gender of Informant & 9. جـ جنس جواب دهنده \\
\hline 7. Age & 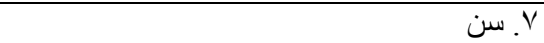 \\
\hline 8. Place of Birth & 1. 1. محل تولد \\
\hline 9. Residence (now/other) & 9 . محل زندكى ميكرديد (فعلى، قبلاً) \\
\hline 10. Mother Tongue & · . لسان مادرى جو اب دهنده \\
\hline 11. Parents' Mother Tongue & II لـسان اصلى بدر و مادر \\
\hline 12. Education Level & r I. درجه تحصيل \\
\hline 13. Spouse's Mother Tongue & "1 ا. لسان اصلى شور / خانم \\
\hline 14. Education Level & 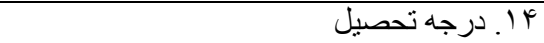 \\
\hline 15. Profession & ه ا. وظيفه \\
\hline $\begin{array}{l}\text { 16. Travel Patterns, general } \\
\text { (destination/frequency/duration/language) }\end{array}$ & 19. سفر (به كذا، جنـ وقت، جققدر وقت، زبان) \\
\hline
\end{tabular}

\section{Post-Testing Questions}

\begin{tabular}{|c|c|}
\hline 1. Where does the storyteller come from? & 1. نفر كه قصه ميكويد كجاى هست؟ \\
\hline 2. Was it good Ishkashimi/Sanglechi? & 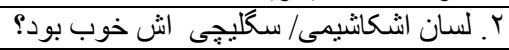 \\
\hline 3. How much did you understand? & r. جقدر فحمديد? \\
\hline 4. How different is the language from yours? & r r. از زبان شما جقدر فرق دارد؟ \\
\hline $\begin{array}{l}\text { 5. Contact with the people from that area? } \\
\text { (travel/extended time/living) }\end{array}$ & هـ نفر هار ا از آنجا ميشناسيد؟ \\
\hline
\end{tabular}

\section{RTT Story: The Well of Everlasting Life}

\section{Section 1}

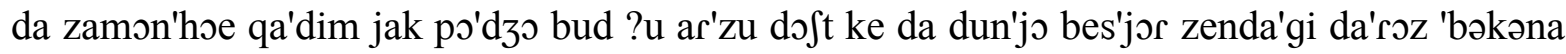
In the old times there was a king. He had the wish to live very long in this world.

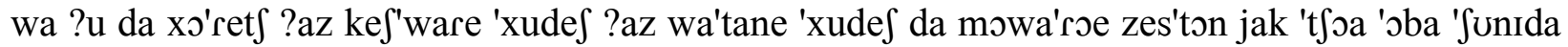
bud ke ?az ?u ?ob ?ar 'kase ke buxora to hame'fa zen'da 'memona

He had heard that outside of his own country in a place called Zestan there is a well and everyone who drinks its water will live forever.

\section{Section 2}

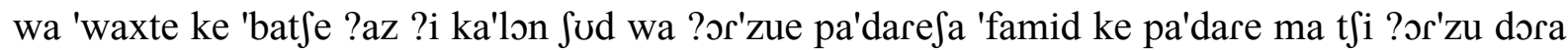
And when his son became grown he understood his father's wish and what his father wanted.

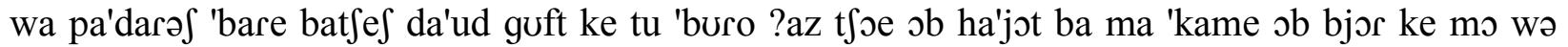
to ?az ?u ?ob 'buxэrem wa to 'hame $a$ a zen'da 'bemonem

The father said to his son, David: Go and bring me some water from the well of everlasting live so that you and I will drink from this water and live forever.

\section{Section 3}

'waxte ke ?i gapa bare ba't $\int \mathrm{e} \int$ guft ba't $\int \mathrm{e}$ '?azme sa'far kad wa ba ta'rafe 't When he had said this to his son, the son departed and left for the well of everlasting life.

bes'jor sa'fare dur wa da'roz kat

He went on a very far and long journey. 
?az har 'kase ke ?u pər'son 'mekad 'bare ?az ?u du'rust ne' $o n$ 'namedoda He asked everyone but no one showed him the right way.

\section{Section 4}

ba jak kes'mate ?az ro ?o'mad ke jak ?o'dame 'pire ya'riba did At one point of the journey he saw an old and poor man.

wa ?az ?u ?awal sa'lom dod boz pər'son kad ke 'tfoa 'oba ba ma ne'fon 'bete He greeted him first and then asked him to show him the place of the well.

'waxte ke ?u 'gape 'bat

When he heard what the king's son said he told him:

t5əe ?ob '?uqadar dur 'namonda taq'riban jak kilo'metər so dur'tar 'monda

The well of everlasting life is not far away, you have about one kilometer road left.

\section{Section 5}

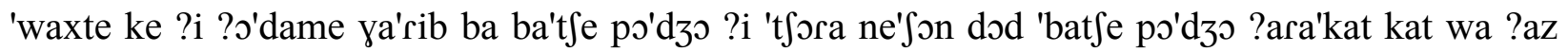
?u bes'jor taSako'ri 'kad

When the poor man had shown the place to the king's son, the king's son continued on his way und he thanked him very much.

'waxte ke ba'tfae po'dzo ?ara'kat kat pas ?a'mi 'marde pir sa'do kad

When the king's son continued on his way the old man cal-led him back.

wə 'bare $\int$ guft 'waxte ke tu ba nəz'dike a'mu уюу 'rasidi da 'undzə jak 'murye ?oq'el ?as ba ga'poe ?az ?u xub du'rust gof 'kuni

And said to him: When you have arrived near the cave, there is a wise bird. Listen very well to his talk.

\section{Section 6}

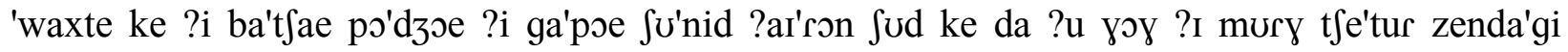
'mekuna wa t $\int e^{\prime}$ tur ?u ba ma gap 'mezana

When the king's son heard this he became very surprised and wondered how this bird would live in the cave and how it would talk to him.

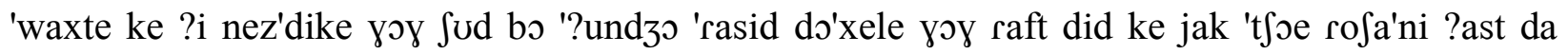
'?undzo wa jak 't $\int$ e ? ob bes'jor t $\int \jmath^{\prime} q u r$ ba ta'rafe za'min ?ast

When he came near to the cave and arrived there he went inside the cave and he saw that there was a shining place and a very deep well in the ground.

\section{Section 7}

?u nez'dike satl sud wa 'mexost ke ?az t 5 ? ob 'brgira

He went close to the bucket and wanted to take water from the well. 


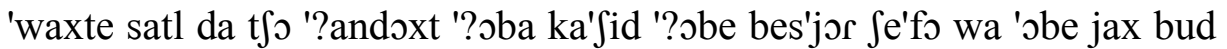
When he dropped the bucket into the well and pulled water up, the water was very healthy and cool.

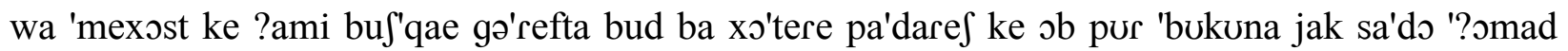
wa jak sa'dora 'Sunid

And he wanted to fill the container he had taken for his father when a sound came and he heard a voice.

\section{Section 8}

guft 'sabr kun to 'waxte ke ga'poe 'mara 'me nnawi tu '?sba pur 'nakun

It said: Wait, do not fill it with water until you have heard what I have to say.

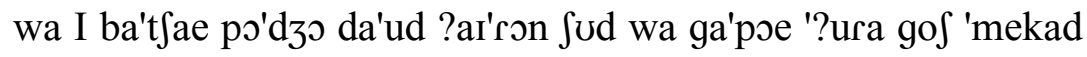

David, the king's son was surprised and he listened to him.

ba ta'rafe bo'lo sarl kad jak 'murye bes'jor pir da bo'loe jak tfob da jak so'ja 'Sifta

And he looked up and there was a very old bird sitting on a branch in the shade.

\section{Section 9}

wə ?u guft ma jak 'murye bes'jor dza'won wə sehat'mand 'budum da ha'wo par'woz 'mekadum And it said: I once was a very young and healthy bird.

'waxte ka ma ?az ?i '?obe t $\int$ o 'xurdum de'ga ma par ?o 'bore ma 'rexta bes'jor pir as'tum wə za'if Su'dum t $\int \mathrm{e}$ 'moe ma 'namibina

I flew in the air. But when I drank water from this well my feathers and wings fell out. I am very old now and I became weak and my eyes can't see any more.

\section{Section 10}

boz ?i ba'tfa 'waxte 'gapoe ?ira 'Sunid hai'ron Sud

When the boy heard this talk he became surprised again.

guft hamqato's ma ?andews'loe ma da ha'ws par'wsz 'mekunan wa uns 'waxte ke 'mara 'mibinan 'pufte ma het $\int$ na'megardan ?az xo'tereke ma ham zen ?o 'sole ?uno nestum

It said: My peers and my friends fly in the air and when they see me they don't turn to me because they are not of my age any more.

\section{Section 11}

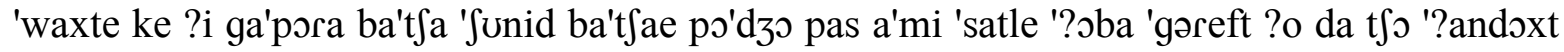
When the boy heard this talk, the king's son took the bucket with the water again and poured it into the well.

wə guft ke ma 'merum ba pa'darem 'megojum ke zenda'gi da ?i dun'jo ba '?umre da'roz ba dard 'namexora

And he said: I will go and tell my father that it is useless to live long in this world. 
wa ba'tfae po'dzo pas '?oba 'rezond wə ?ara'kat kad ba ta'rafe xo'na The king's son poured the water back and left for home.

\section{Section 12}

'waxte ke ?ara'kat kat wə da ro ba 'gape ?a'mi mury 'feks 'mekad wə tfurt 'mezad When he left he pondered and thought about what the bird had said.

har 'kase ke da 'fekre dza'nat wa zenda'gi ka'dan da dza'nat 'bofa wa ?u da 'fekre ?i 'bofa ke da

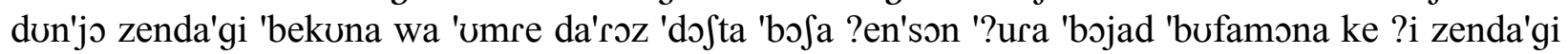
?i dun'jo ba dard 'namexura

Everyone who does not have the paradise and life in paradise in his mind, and who thinks about life in this world and who wants a long life, this person should know that life in this world is useless.

\begin{tabular}{|c|c|c|c|}
\hline \multicolumn{4}{|c|}{ RTT Scoring } \\
\hline Section 1 & - & Section 7 & 1. took bucket \\
\hline & & & 2. fetch water \\
\hline & & & 3. cool and good/healthy \\
\hline & & & 4. heard a voice \\
\hline \multirow[t]{4}{*}{ Section 2} & 1. son & Section 8 & 1. don't take water/wait \\
\hline & 2. go and bring water & & 2. surprised/listened \\
\hline & 3. live forever & & 3. looked up \\
\hline & & & 4. bird on branch \\
\hline \multirow[t]{4}{*}{ Section 3} & 1. boy went to get water & Section 9 & 1. once was a young bird \\
\hline & 2. asked people for the way & & 2. drank from the water \\
\hline & 3. no one could tell him & & 3. I'm old now \\
\hline & & & 4. feathers fell out \\
\hline \multirow[t]{4}{*}{ Section 4} & 1. old man & Section 10 & 1. my friends/peers fly \\
\hline & 2. boy greeted him & & 2. don't look at me \\
\hline & 3. asked for the well & & \\
\hline & 4. it's not far & & \\
\hline \multirow[t]{3}{*}{ Section 5} & 1. thanked & Section 11 & 1. poured water back \\
\hline & 2. bird & & 2. went back home/tell my father \\
\hline & 3. listen to it & & 3. long life is not useful \\
\hline \multirow[t]{4}{*}{ Section 6} & 1. boy surprised & Section 12 & 1. pondered \\
\hline & 2. how will the bird talk? & & 2. life in this world is useless \\
\hline & 3. cave & & 3. paradise \\
\hline & 4. bright place and deep well & & \\
\hline
\end{tabular}




\section{Appendix E: Poems recorded in Jumarj-e Bālā and Nusay}

\section{Jumarj-e Bālāa}

\author{
da 'roe 'tange 'rorəmə \\ da 'rəe bo'ryk 't \\ dar in t $\int \partial^{\prime}$ in talx owa'ra \\ aq'lu: fa'ra aj 'kokəmə \\ u'ma a'rab 'kohe a'dzam \\ zaro'wa gas'ta dəl zə'yam \\ dar in tfo'nin talx owla'ra \\ aq'lu: fa'ra aj 'kskəmə
}

I walk a narrow road

I go a tight way

What do I do on this bitter road?

Where do I get strength from?

I get stuck everywhere I walk.

Everywhere I go with a heart is bitter.

How did I get on this bitter road?

Where do I get strength from?

\section{Nusay $^{9}$}

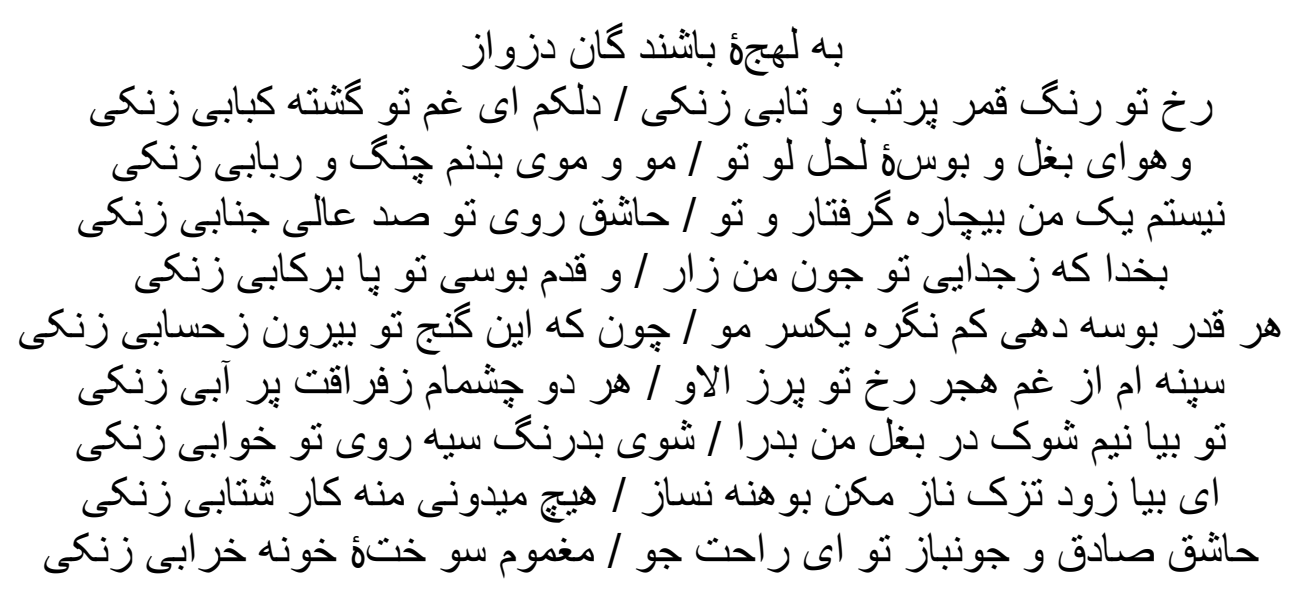

ba laha'dzae bəSənda'gonə dar'wo:z

'ruxə tu 'rangə qa'mar pur tub u 'to:baj zə'naki / də'lakum aj 'yamə tu gaf'ta ka'bə:baj zə'naki wa ha'woe ba'yale $u$ bu'sa $o$ 'lahle 'lawe tu / mu: muje ba 'danem tfang $v$ ru'bobaj zə'naki

'nestam jak 'mane bet $\jmath^{\prime} r a$ girif'tore tu / ho'Suqə 'ruje tu sad 'olə dza'no:baj zə'naki ba xo'do ke zidzIdo'ji tu 'dzunə manə'zo: / wa 'qadəm bu'se: tu po'barə 'kəbaj zə'naki har 'qadar bu'sa 'dihi kam 'nagara jak'sarə mu: / tfin kə i:n 'gandzə tu be'run zəhe'sobaj zə'naki

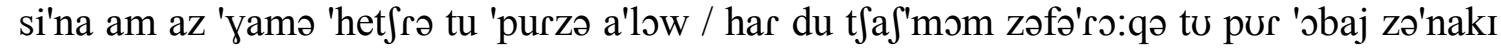
tu 'bio 'nimə Sa'wak dar ba'yalə man 'bədaro / 'Sue bad'range sia rue tu 'xo:baj zə'naki

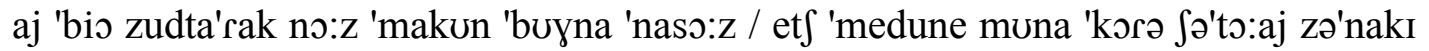
ho'frqə so'diqə dzun'bə:zə tu aj rə'hatə dzu / may'mumə sux'tae xu'na xa'rø:baj zə'naki

\footnotetext{
${ }^{8} \mathrm{~A}$ man cited the poem by heart. It was well known to everyone around. He verbally translated it into Dari.

${ }^{9} \mathrm{~A}$ man had a collection of poetry, one of them was written in Darwāzi using arabo-persion script. He read it out for the researchers and then translated it verbally into Dari.
} 


\section{In the dialect of the dwellers of Darwāz}

Your face is shining like the moon; my heart burns like kebab for you.

I wish to embrace you and to kiss you; my hair is like strings on a harp that play for you.

Not only I am in love with you; a thousand other men love you also.

I am suffering whenever we are separated; I hope you mount a horse so I can kiss your feet.

However often you kiss me, it is never too much; you cannot kiss me often enough.

My heart burns for you like fire; I cry when you are far from me.

Come close to me in the middle of the night; your useless husband will not wake up.

Come quickly, don't tell you husband; come quickly, it's urgent.

My body always suffers for you until you calm it; Maghmum has always sorrow in his heart. 